\title{
From tolerance allocation to tolerance-cost optimization: a comprehensive literature review
}

\author{
Martin Hallmann $^{1}$ (D) $\cdot$ Benjamin Schleich ${ }^{1}$ (D) . Sandro Wartzack ${ }^{1}$ (D)
}

Received: 7 December 2019 / Accepted: 26 March 2020 / Published online: 8 May 2020

(C) The Author(s) 2020

\begin{abstract}
It is widely acknowledged that the allocation of part tolerances is a highly responsible task due to the complex repercussions on both product quality and cost. As a consequence, since its beginnings in the 1960s, least-cost tolerance allocation using optimization techniques, i.e. tolerance-cost optimization, was continuously in focus of numerous research activities. Nowadays, increasing cost and quality pressure, availability of real manufacturing data driven by Industry 4.0 technologies, and rising computational power result in a continuously growing interest in tolerance-cost optimization in both research and industry. However, inconsistent terminology and the lack of a classification of the various relevant aspects is an obstacle for the application of tolerance-cost optimization approaches. There is no literature comprehensively and clearly summarizing the current state of the art and illustrating the relevant key aspects. Motivated to overcome this drawback, this article provides a comprehensive as well as detailed overview of the broad research field in tolerance-cost optimization for both beginners and experts. To facilitate the first steps for readers who are less familiar with the topic, the paper initially outlines the fundamentals of tolerance-cost optimization including its basic idea, elementary terminology and mathematical formulation. These fundamentals serve as a basis for a subsequent detailed discussion of the key elements with focus on the different characteristics concerning the optimization problem, tolerance-cost model, technical system model and the tolerance analysis model. These aspects are gathered and summarized in a structured mind map, which equips the reader with a comprehensive graphical overview of all the various facets and aspects of tolerance-cost optimization. Beside this, the paper gives a retrospect of the past fifty years of research in tolerance cost-optimization, considering 290 relevant publications. Based thereon, current issues and future research needs in tolerance-cost optimization were identified.
\end{abstract}

Keywords Tolerance synthesis · Tolerance optimization · Tolerance-cost optimization · Least-cost tolerance allocation · Optimum tolerance design $\cdot$ Optimal tolerance assignment

\section{Motivation}

Despite the continuous improvements of manufacturing and measurement, geometrical deviations are unavoidable due to manufacturing and measurement imperfections [1]. These deviations, however, mainly influence the quality of mechanical products throughout their entire product life cycle $[2,3]$. In order to limit the unintentional part deviations, the designer specifies and allocates tolerances to ensure the fulfillment of specified quality requirements.

Martin Hallmann

hallmann@mfk.fau.de

1 Engineering Design, FAU Erlangen-Nürnberg, Martensstrasse 9, 91058 Erlangen, Germany
In this regard, tolerance allocation is a key task in design engineering and associated with high responsibility for product functionality as well as for profitability.

In general, tolerances are allocated on the basis of experimental data, previous drawings and expertise [4]. In this context, manual approaches are common to check and assign the tolerance values on a trial-and-error basis [5-8]. In doing so, the resulting manufacturing costs are mostly neglected or merely indirectly considered by qualitative thumb rules like "the lower the tolerance the higher the cost of manufacturing" [4]. Moreover, traditional tolerance allocation methods require extensive time and effort [4] and do not lead to a least-cost tolerance design due to their unsystematic procedure and the lack of considering quantitative (tolerance-) cost information [5].

For a more efficient and sophisticated tolerance allocation considering both quality and cost issues, various 
methods for optimal tolerance allocation using optimization techniques, i.e. tolerance-cost optimization, steadily evolved since its beginnings in the mid-twentieth century [9]. Especially in times of rising cost and quality awareness and the availability of manufacturing data in a digitalized, highly computerized production, it is seen as an important key element in industry [10-13] to bridge the gap between manufacturing and design [14] and to create a balance between manufacturing costs and quality [15].

However, the complexity of tolerance-cost optimization with its interdisciplinary elements is currently an obstacle for its profitable implementation and application in the industry [5]. In comparison with tolerance analysis, it is regarded as complex and challenging $[5,16]$.

Despite the broad field of related domains, the number of publications reflecting the state-of the art is limited. Existing review articles, e.g. [9, 17-21], indeed address the relevant topics in a suitable and illustrative manner but are either not up-to-date or focus merely on certain specific aspects. However, a comprehensive review of tolerance-cost optimization is missing so far.

With the aim to close this gap, the following review article gives a comprehensive overview of tolerance-cost optimization and discusses the relevant topics in detail. In doing so, the different aspects of manufacturing, tolerancing, optimization and their interrelations are illustrated using a car disk brake system as a case study of industrial complexity (see Fig. 1).

The article is subdivided into three major parts: Firstly, Section 2 illustrates the role of tolerance allocation in the design process and presents the basic idea and the mathematical description of tolerance-cost optimization.

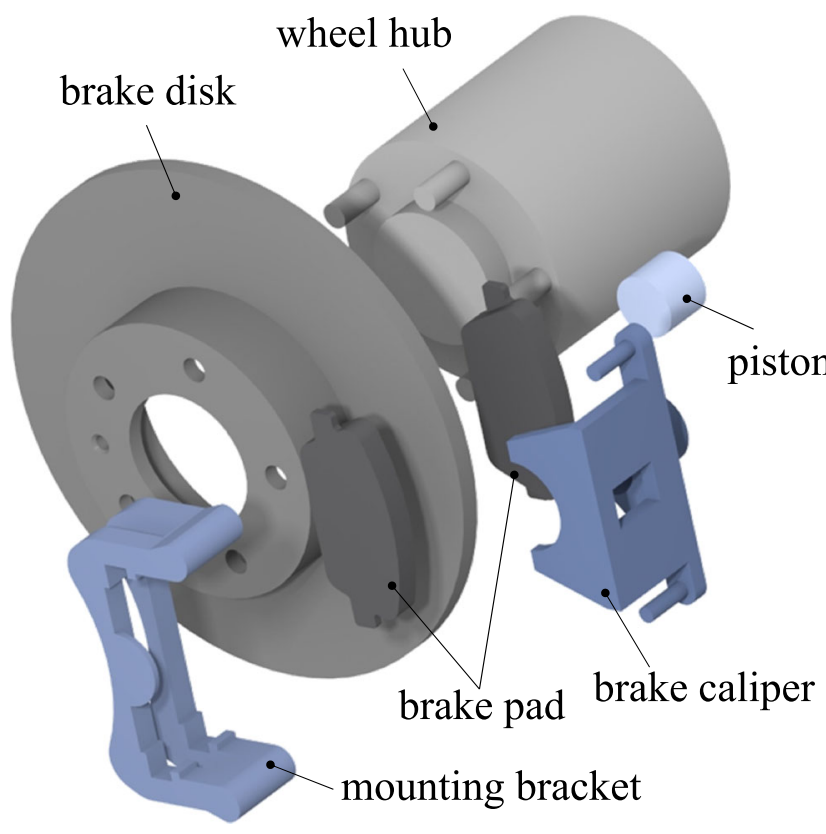

Fig. 1 Case study: car disk brake system [22]
Based on these fundamentals, Section 3 discusses the different aspects in detail. While Section 3 initially summarizes and categorizes all relevant aspects in a comprehensive mind map, the subsequent Sections 3.1-3.4 present the various details of tolerance-cost optimization and their interrelations. After that, Section 4.1 gives a comprehensive review of the last five decades of research in the field of tolerance-cost optimization. For this purpose, an extensive literature review of 290 research articles serves as a basis for discussing the current and future trends and to identify future research needs in Section 4.2. Finally, Section 5 summarizes the article.

\section{Fundamentals of tolerance allocation and tolerance-cost optimization}

The following section equips the reader with the fundamentals of tolerance allocation and tolerance-cost optimization and is particularly tailored to interested researchers and practitioners who are less experienced in these topics. As a consequence, experienced readers may skip this section and straightly continue with Section 3.

\subsection{The role of tolerancing in design engineering}

A successful development of high-quality products necessitates the fulfillment of requirements of a wide variety of interest groups. Consequently, conflicts of interests and competing objectives dominate and shape the product development process [23]. When detailing the product design in the different phases of the design engineering process, a balance must be created between the conflicting objectives, especially between quality and cost, to increase productivity $[24,25]$. Motivated by this need, TAGUCHI proposed a three-step approach for a successful assignment of the nominal design parameter values and tolerances [24, 25] (see Fig. 2).

Firstly, the system design is used to define the product configuration by applying different methods for the identification, evaluation and selection of solutions with respect to product robustness [24, 25]. Secondly, the nominal values for the design parameters are determined in the parameter design [25]. Thirdly, the tolerance design is intended to assure product quality by limiting the deviation of the geometry from nominal [24, 25]. In doing so, first general ideas are systematically turned into conceptual solutions and finally into the documented detailed product design.

\section{Robust design}

All these early and late phases of the design engineering process are accompanied by the paradigm of robust 


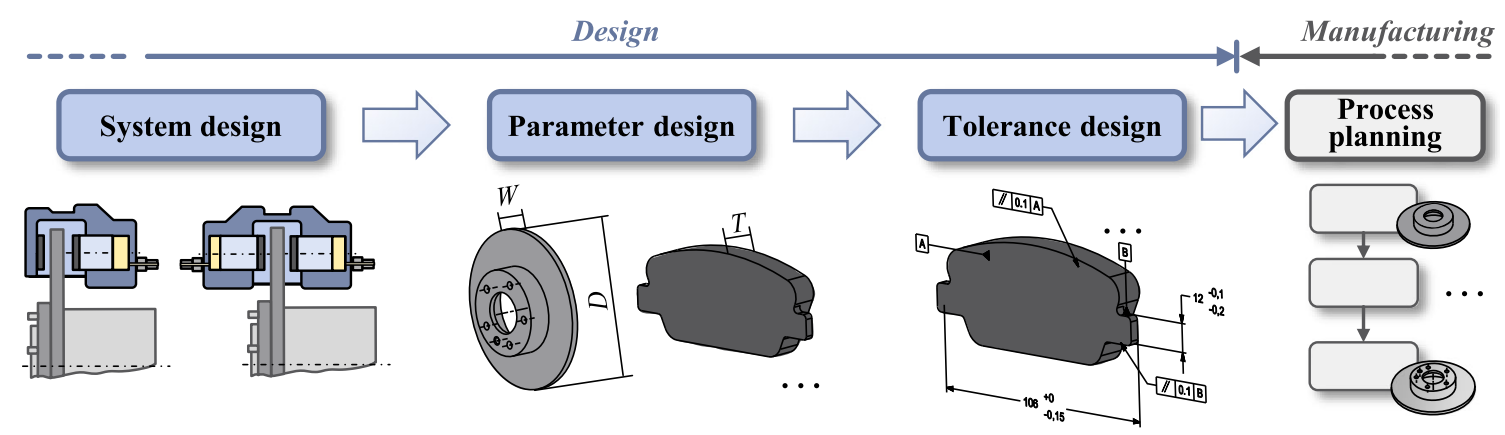

Fig. 2 Off-line quality control in design engineering according to TAGUCHI: system design, parameter design, tolerance design

design [26, 27], i.e. improving the robustness of a system in terms of quality, reliability and costs [28]. Focusing on this global aim, a huge number of robust design techniques for system, parameter and tolerance design are used to reduce the sensitivity of design parameters of a system under uncertainties [9, 24, 29]. In tolerance design, this aspect is mainly incorporated by a concurrent optimization of dimensions and tolerances to achieve a so-called robust tolerance design at minimum cost $[30,31]$. In doing so, numerous authors adopt the basic idea of TAGUCHI's quality loss and integrate this aspect in tolerance design (see Section 3.2.2) [9]. These approaches take into account that any deviation from the target value results in an additional loss for the customer [32-34].

\section{Tolerance design for manufacturing}

Besides the important aspects from design, tolerance design has to consider numerous manufacturing issues to enable a profitable fabrication of quality products. Process planning is often seen as the missing link between design and manufacturing [35] that can help to bring the manufacturing concerns into the design process (see Fig. 2) [36]. While the design tolerances $t$ are assigned with focus on the requirements of a mechanical assembly or a component in use, the machine or process tolerances $\delta$ are required to create a process plan for part manufacturing [17]. Therefore, the design tolerances are the result of a sequence of machining tolerances realized by a sequence of different machining operations (see Fig. 3).

Traditionally, the specification and allocation of design and process tolerances are done by two separated divisions, by design and manufacturing [37, 38]. Door by door, methods supporting the assignment of manufacturing tolerances have concurrently evolved over the years. Therefore, tolerance transfer plays an important role as it attempts to convert the design tolerances into a production plan by using tolerance analysis and synthesis methods [39]. Thereby, a tolerance chart is used as a graphical representation of the process plan and serves as a basis to control the dimensions of a workpiece with its tolerances [40-43]. The tolerance chart balancing techniques aim to widen the tolerances without violating the blueprint specifications using both qualitative and quantitative cost information [44]. In its beginnings, these methods were associated with a great deal of manual effort and their usage was mainly experience-driven [43, 45, 46]. By successively computerizing them, they nowadays play an important role in computer-aided process planning (CAPP) [17, 47-49]. Huge effort was incurred to create mathematical models for tolerance chart allocation and solving them using optimization algorithms [39].

\section{Concurrent tolerance design}

For a long period of time, this separated view of design and manufacturing was quite common [50]. Pushed by the revolutionary stream of concurrent and simultaneous engineering, the machine tolerances were steadily integrated in the framework of tolerance design [17, 46, 51]. By linking both disciplines, various aspects of process planning, such as multi-station manufacturing processes, stock removal allowance, tolerance charting, process scheduling and tolerance-cost models including process parameters and machine accuracy, can simultaneously be considered [14, 51-55]. Such integrated approaches intend to better link design and manufacturing by transferring the relevant elements from process planning into tolerance design. In doing so, numerous information and aspects from manufacturing

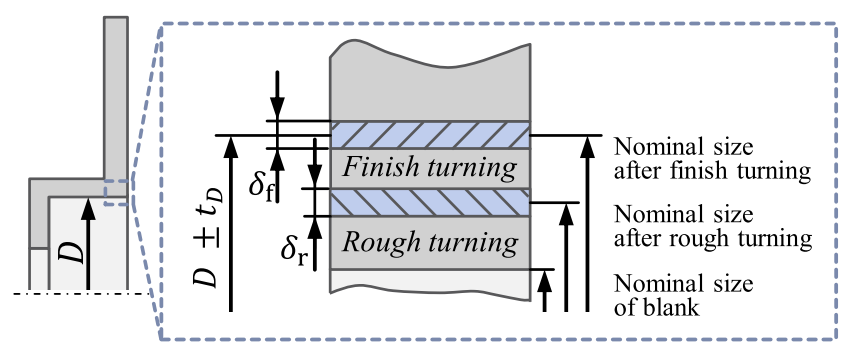

Fig. 3 Car brake disk: manufacturing and design tolerances in comparison freely adapted from [9] 
and inspection have to be incorporated in tolerance design. Due to this, tolerancing plays a responsible and decisive key role in the product development process.

\subsection{Important issues in tolerancing}

Tolerances are primarily assigned to control the inevitable part deviations and their effects on the total product quality $[1,56]$. However, a proper assignment of part tolerances is a demanding task necessitating a number of different tolerancing activities (see Fig. 4) [56].

Initially, the product requirements must be translated into a set of geometrical requirements which are subsequently decomposed from product to assembly and part level. In doing so, essential features, often called key characteristics $(\mathrm{KC})$, are identified. They significantly influence the fulfillment of the product requirements if they vary from nominal [57].

Afterwards, the tolerance specification is used to define the tolerance types for all relevant features in compliance with current tolerancing standards addressing the qualitative issues of tolerancing [58, 59]. Based on the tolerance

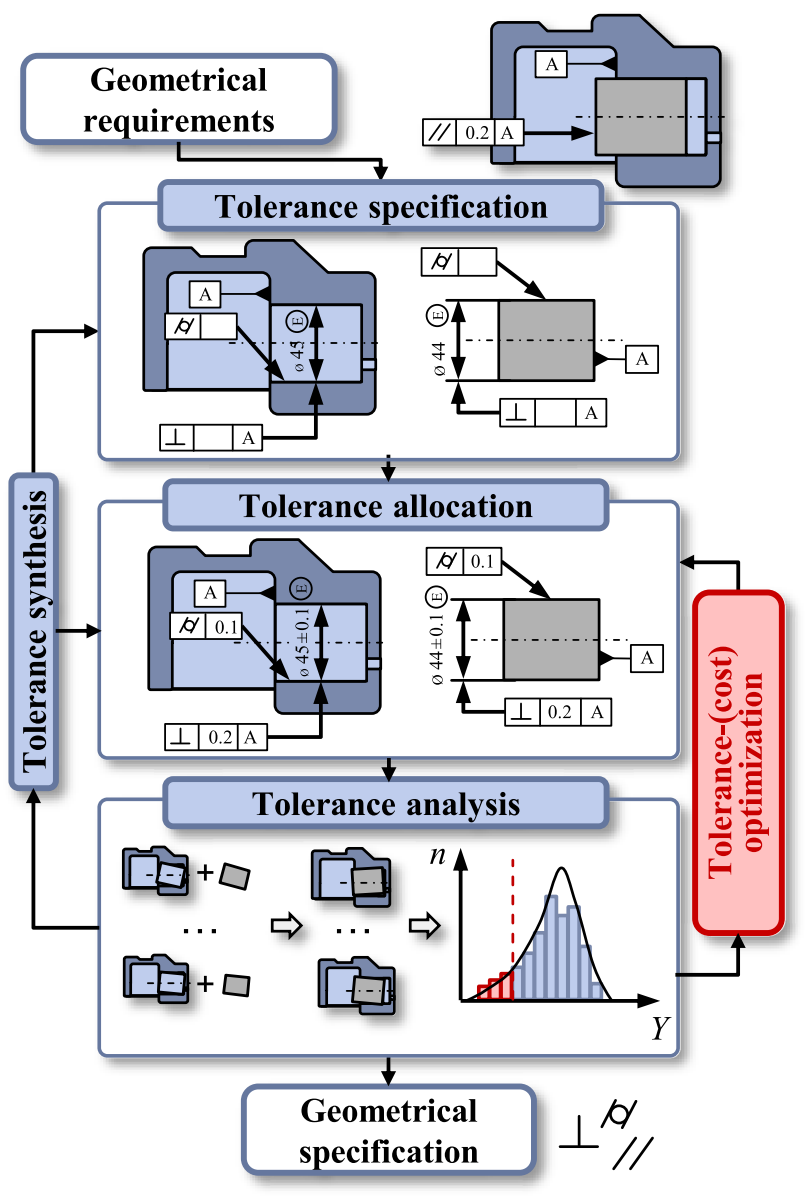

Fig. 4 Classification of tolerance specification, allocation, analysis, synthesis and optimization according to [56] specification, an appropriate value for each tolerance has to be assigned in the subsequent step of tolerance allocation (see Section 2.3). The initially allocated tolerances serve as a basis for the tolerance analysis which helps to study the effects of the part deviations and to check the fulfillment of the predefined quality objectives $[39,60]$.

In contrast to tolerance analysis, tolerance synthesis starts with the requirements of the KCs and identifies suitable tolerance values as well as tolerance types by considering the results of iterative tolerance specification, tolerance allocation and tolerance analysis in a common synthesis step (see Fig. 4) [61].

Driven by the demands of high-quality products, tolerance optimization aims to achieve an optimal tolerance allocation by selecting a set of tolerance values while the tolerance specification is fixed [39]. The usage of optimization techniques helps to identify the best tolerance values in terms of quality [9].

Challenging enough, the tolerance engineer is also responsible for the resultant costs caused by the assigned tolerances. For this purpose, tolerance-cost optimization plays an important role since it covers both quantitative quality and cost information to realize an optimal tolerance allocation [12].

\subsection{Tolerance allocation}

As highlighted, tolerance allocation corresponds to assigning and distributing the tolerance values among the parts of an assembly [59, 62]. In general, tolerances are primarily assigned for functionality mostly based on expertise or empirical data. In doing so, the cost aspect is neglected or only indirectly taken into account [63]. As a consequence, tolerances are typically chosen tighter as necessary to ensure product quality [64]. This leads to high-quality products but also to higher manufacturing costs $[63,65]$. The identification of a valid set of tolerance values creating a balance between quality and cost is a challenging task. In order to solve this conflict (see Fig. 5), three main questions must be answered [66]:

1. "How good does the product have to be?"

2. "What can be done to improve the quality of the product?"

3. "What is the most profitable action to take?"

With the aim to answer these questions, various methods have been developed over the last decades:

\section{Traditional methods}

Numerous approaches of tolerance allocation date back to a time where computer technology was either not available at all or their capability was strongly limited. Besides 


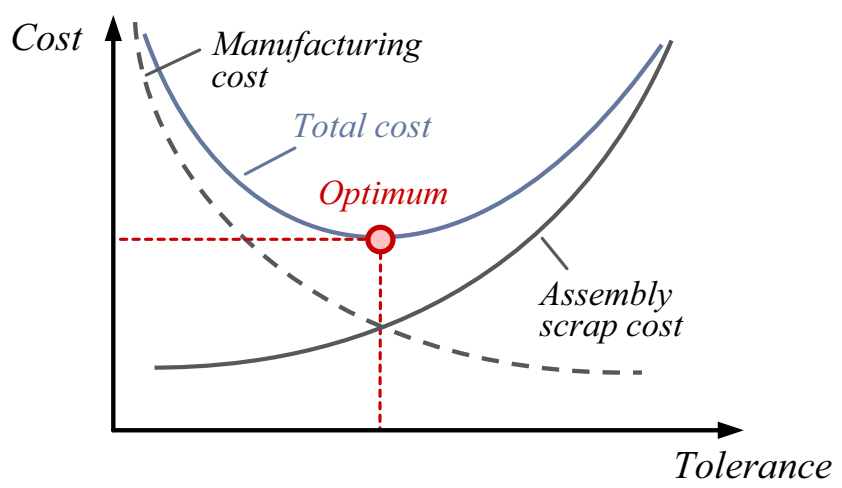

Fig. 5 Quality-cost conflict in tolerance allocation according to [67]

graphical approaches [68, 69], several analytical methods have emerged in those years, e.g. equal scaling by the same tolerance or same influence method or proportional scaling by using different weighting factors [70-73]. However, these methods are often based on rough rules of thumb [72, 74] and do not consider any quantitative cost information [21, 72]. As a consequence, their applicability is strongly limited and they are not sufficient for defining a tolerance design that withstands the quality and cost pressure in modern product development. Consequently, they are mostly used for a preliminary tolerance assignment in early design stages $[21,74]$ serving as a basis for subsequent optimization procedures today.

\section{Manual, iterative application of tolerance analysis}

In contrast, the iterative application of tolerance analysis is more common to check and assign the tolerance values on a trial-and-error basis $[6,8,75]$. Beginning with guessed or purposely assigned tolerances, the designer analyzes the design for the current tolerances and checks if the quality requirements are met. If the current allocation fails, tighter tolerances have to be assigned. Otherwise, wider tolerances leading to reduced manufacturing costs can be chosen [76]. Hence, the additional use of sensitivity analyses helps to identify the relevant tolerances by determining the contribution of each tolerance to the $\mathrm{KC}[77,78]$. Afterwards, the most relevant tolerances are manually adapted. This manual re-allocation step is repeated until the tolerance expert is satisfied with the current solution [78]. Despite its usability, this approach is very time-consuming [75] and leads to non-optimal solutions since there is no quantitative cost information taken into account [78].

\section{Quality engineering methods}

Alternatively, quality engineering and statistical methods are applied to solve the tolerance-cost conflict [18] since they are regarded as practicable for complex mechanical assemblies [39, 79] and they convey process knowledge [80]. Hence, different methods of design of experiments (DOE) in combination with analyses of variance (ANOVA) are used to identify an optimal tolerance design [18, 81-83]. However, these approaches are not universally applicable and do not necessarily lead to optimal results.

\subsection{Tolerance-cost optimization}

To overcome the drawbacks of the previously discussed approaches, the tolerance allocation problem can be formulated as a mathematical optimization problem and solved with the aid of deterministic and stochastic optimization algorithms [9]. In contrast to the open loop structure of the manual, repetitive application of tolerance analysis [84], the tolerance re-allocation is automatically performed within the optimization process considering both quality and cost information quantitatively [12]. Using the example of the brake disk, the tolerance values of the individual components are thus optimally chosen to both assure the braking performance and to achieve a cost-efficient tolerance design by considering the relations between the assigned tolerances and the resultant manufacturing costs.

Not least due to its great potential, the usage of optimization techniques for tolerance allocation has arisen the interest of a great number of research activities over the last years. As a consequence, several terms for tolerance-cost optimization were coined and synonymously used in literature. In addition to the term tolerance(-cost) optimization [12, 85-87], any combination of the terms optimum [38, 88-90], (cost-) optimal [91-95], minimum cost $[64,76,96,97]$ or least-cost [98-102] and a more or less interchangeable term for tolerance allocation [98, 99, 103, 104], such as tolerance assignment [76, 88, 105-107], tolerance selection $[38,63,86,108,109]$, tolerance allotment [91, 110-112], tolerance distribution [62, 72, 113], tolerance synthesis $[89,90,114,115]$ or tolerance design $[6$, $93,110,116,117]$, is used. Since first applications in the 1960s, tolerance-cost optimization has successively evolved and is the preferred approach for (cost-) optimal tolerance allocation today.

\subsubsection{Basic idea}

Since the type of tolerance-cost optimization and its implementation strongly depends on its objective [18], it can be interpreted in different ways. In most cases, however, it aims to minimize the manufacturing costs $C_{\text {sum }}$ (objective) while ensuring the fulfillment of the quality requirements by keeping the lower and/or upper specification limits for the KCs to $Q_{\min }$ (constraint) $[39,98]$. 
Therefore, the optimizer has to identify an optimal combination of tolerances $t=\left[t_{i}, \ldots, t_{I}\right]^{\mathrm{T}}$. The design variables $t_{i}$ define the design space which is constrained by the lower $t_{i, \min }$ and upper boundaries $t_{i, \max }$ in compliance with the manufacturing process limits. Mathematically spoken, least-cost tolerance-cost optimization corresponds in its most simple way to a single-objective optimization $[9,99]$ :

$\begin{array}{llr}\text { Minimize } & C_{\text {sum }}(t) & \text { (objective), } \\ \text { subject to: } & \hat{Q}(t) \geq Q_{\text {min }} & \text { (constraint), } \\ & t_{i, \min } \leq t_{i} \leq t_{i, \max } \forall i=1, \ldots, I .\end{array}$

For the sake of completeness, it must be mentioned that, besides the popular least-cost tolerance-cost optimization, best-quality tolerance cost-optimization by maximizing the quality $\hat{Q}(t)$ without exceeding a predefined cost limit $C_{\max }$ has been reported [118]. Therefore, objective and constraint are reversed leading to an optimization problem of maximize $\hat{Q}(t)$ subject to $C_{\text {sum }}(t) \leq C_{\max }$ and $t_{i, \min } \leq$ $t_{i} \leq t_{i, \max } \forall i=1, \ldots, I$..

For both optimization problem formulations, the detailed optimization procedure for solving the tolerance-cost problem is mostly shaped by the chosen optimization algorithm with its individual settings to handle the relevant design variables, objectives and constraints. Nevertheless, the basic workflow for tolerance-cost optimization can generally be represented by Fig. 6 .

The optimization process starts with a combination of initial tolerances $\boldsymbol{t}_{\text {init }}$ [12]. The costs for the current

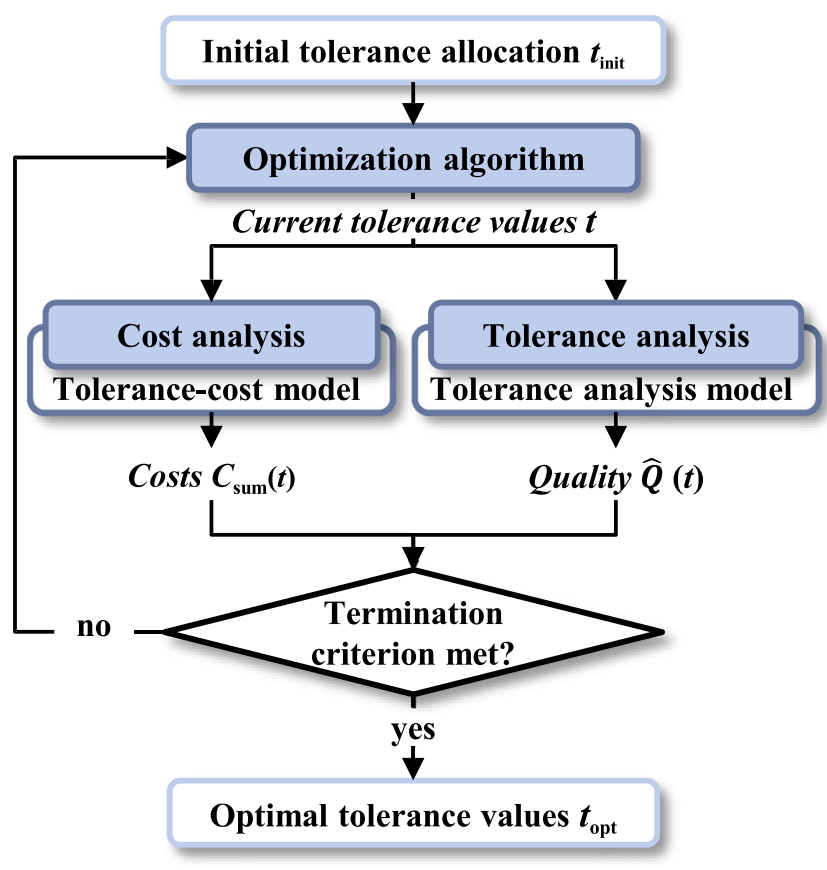

Fig. 6 General workflow of tolerance-cost optimization according to [12] tolerance assignment are estimated via a cost analysis based on a tolerance-cost model which links the allocated tolerances and the resulting manufacturing costs [12]. Hence, the relationships between the costs and each tolerance $t_{i}$ are described by a tolerance-cost function $C_{i}\left(t_{i}\right)$ and together they form the tolerance-cost model $C_{\text {sum }}(t)$ [9]. In addition to the cost analysis, tolerance analysis using worst-case and statistical approaches intends to analyze the system for the currently allocated tolerances [12]. The results verify whether the resultant product quality $\hat{Q}(t)$ meets the requirements and the current tolerance assignment provides a feasible solution [12]. Afterwards, both information of cost and quality are used to evaluate the current solution. Based on this information, a new set of tolerances is selected for the subsequent evaluation in terms of quality and cost by further tolerance and cost analyses [12]. In doing so, the optimization algorithm successively adapts the tolerance values $t_{i}$ in each iteration considering the previous optimization results until a predefined termination criterion is met and the optimal tolerance values $\boldsymbol{t}_{\text {opt }}$ are identified [12].

In summary, tolerance-cost optimization covers all methods that aim to identify an optimal set of tolerances with focus on cost and quality using optimization techniques. This implies that the cost aspect is covered by at least one objective or one constraint.

\section{A comprehensive overview of tolerance-cost optimization}

Based on the fundamentals illustrated in Section 2, the subsequent Sections 3.1-3.4 provide a deeper insight into tolerance-cost optimization. In doing so, an extensive literature review was carried out to obtain a comprehensive overview on the complex and interdisciplinary topic. The literature study has shown that tremendous work has already been done in the past leading to a continuous evolution over the years. However, the different perspectives and the inconsistent terminology make it difficult to identify the main aspects and the interrelations of the various publications.

With the aim to structure the different findings and to create a common, fundamental understanding, the gathered information was categorized into four key elements, viz. the optimization problem, tolerance-cost model, technical system model and tolerance analysis model with its respective categories. As a result, Figs. 7 and 8 present a comprehensive mind map illustrating tolerance-cost optimization at a glance and guiding the reader through the sections without losing track.

This classification additionally intends to assist the tolerance engineer in analyzing and characterizing a given 


\section{Tolerance-cost optimization}

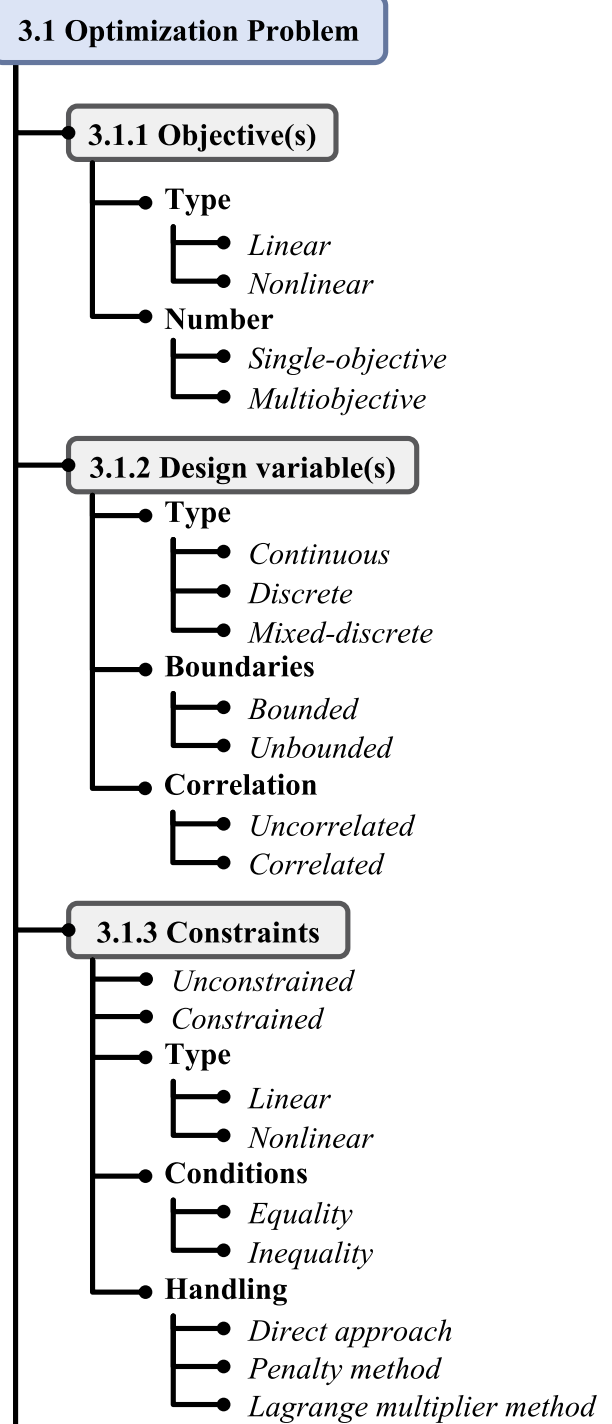

3.1.4 Optimization algorithm

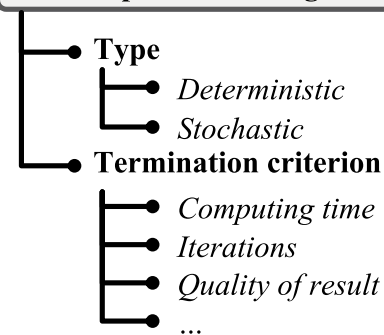

3.2 Tolerance-cost model

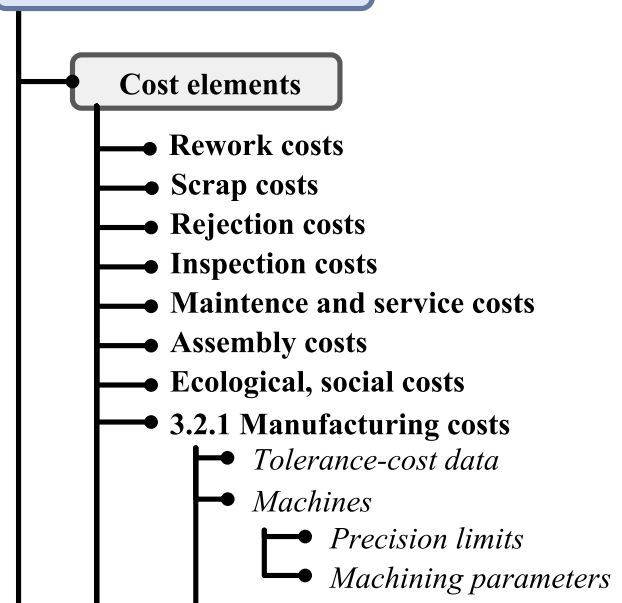

Processes

$\longrightarrow$ Single-stage

Multi-stage

3.2.2 Quality loss

$\longrightarrow$ Symmetrical

$\longrightarrow$ Nominal-the-best

- Asymmetrical

$\longrightarrow$ Larger-the-better

- Smaller-the-better

External supply

...

3.2.1 Tolerance-cost functions

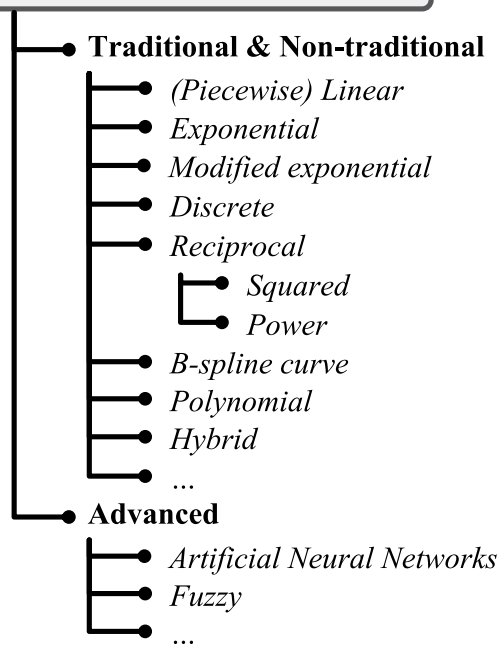

Fig. 7 Holistic overview of tolerance-cost optimization with its key elements and characteristics-part 1 


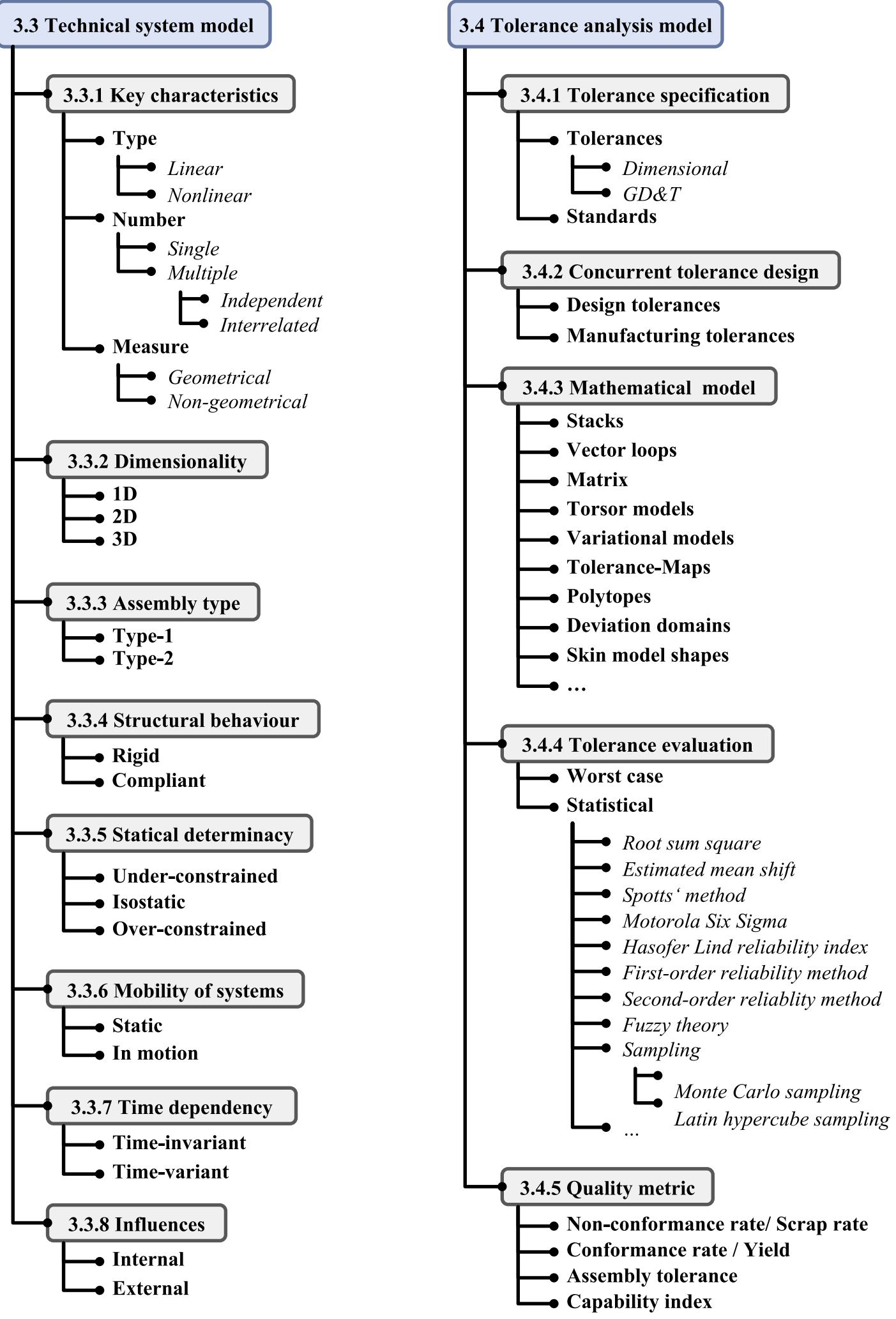

Fig. 8 Holistic overview of tolerance-cost optimization with its key elements and characteristics-part 2 
or newly defined optimization problem. For researchers, the mind map serves as a useful basis to position their work in the overall context of tolerance-cost optimization. Thus, it facilitates to identify current research needs and the novelty of their publications since it is easier to find related work and the interrelations between the different categories.

Even though the proposed classification does not claim to be all-embracing, it takes the most relevant aspects of tolerance-cost optimization of mechanical systems into account. Since the linking of the information is essential to understand the interrelations between the different aspects and terms and to obtain a global understanding of the method, the individual elements are consequently described with respect to the other key elements. Relevant sources are referenced at the respective text passages, however, they are limited to a representative selection for reasons of traceability.

\subsection{Optimization problem}

Optimization generally corresponds to the search of an optimal combination of the design variables $\boldsymbol{X}$ optimizing, i.e. minimizing or maximizing, a given objective function $f(\boldsymbol{X})$. Equality $l_{j}(\boldsymbol{X})$ and inequality conditions $g_{j}(\boldsymbol{X})$ constrain the design space by defining regions of infeasibility (see Fig. 9) [119]:

Find $\boldsymbol{X}=\left[x_{1}, x_{2}, \ldots, x_{I}\right]^{\mathrm{T}}$ which minimizes $f(\boldsymbol{X})$,

subject to

$g_{j}(X) \leq 0, \quad \forall j=1, \ldots, J$,

$l_{k}(\boldsymbol{X})=0, \quad \forall k=1, \ldots, K$.

The design space is further limited by upper and lower boundaries of the design variables [119]:

$x_{i, l b} \leq x_{i} \leq x_{i, u b} \quad \forall i=1, \ldots, I$.

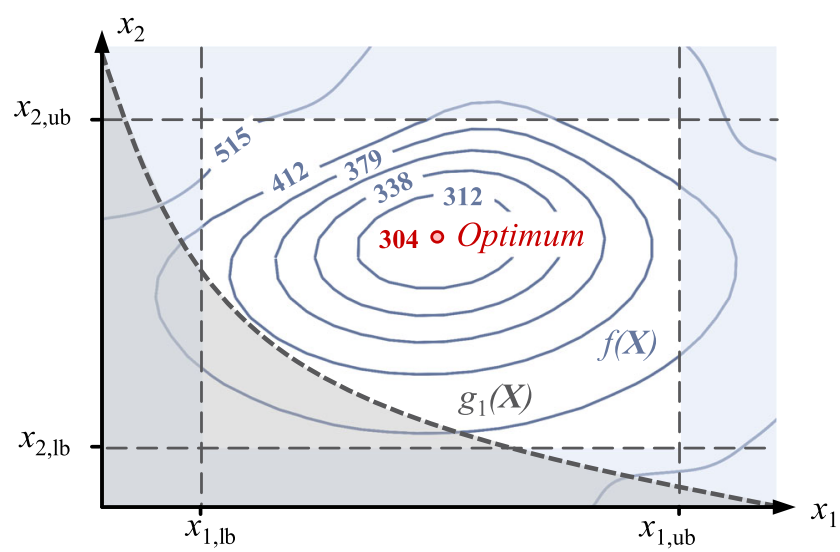

Fig. 9 Two-dimensional design space of function $f(\boldsymbol{X})=f\left(x_{1}, x_{2}\right)$ constrained by the inequality condition $g_{1}(\boldsymbol{X})$
In tolerance-cost optimization it is the most challenging task to adapt the basic formulation of the optimization problem in Eqs. 2-5 to the given tolerance-cost problem. Therefore, the aforementioned aspects have to be interpreted from the perspective of tolerancing.

\subsubsection{Objective(s)}

The objective serves as the criterion to which the design is optimized and is described by a function of the design variables [119]. In tolerance-cost optimization, the choice of the objective function depends on the users global aim and intent [18].

In general, the total costs caused by the allocated tolerances are in focus of tolerance-cost optimization and are thus forming the objective(s) (see Eq. 1). Hence, the costs can either be expressed by the manufacturing costs, by the quality loss, or by both in context of robust tolerance design. In doing so, the tolerance-cost model serves as the objective function. In quality-driven or bestquality tolerance-cost optimization, the objective function predicts the resultant quality by a suitable quality metric, e.g. the manufacturing yield or the process capability (see Section 3.4.5) using the information of the tolerance analysis model.

The type of the objective function significantly influences the choice of the optimization algorithm and its results (see Fig. 7). Linear objective functions are in general easy to solve, but they are insufficient to describe most of real engineering problems. In tolerance-cost optimization, most objective functions are nonlinear (see Section 3.2.1 or Section 3.2.2). By linearization, the initially nonlinear objectives get easier to compute but the results are less accurate due to approximation errors. Instead of simplifying the functions, it is more expedient to apply and enhance powerful algorithms to identify the global optimum of the objectives.

If multiple objectives are concurrently optimized, multiobjective algorithms are required to identify the best combinations of the different conflicting objectives [119]:

$f(\boldsymbol{X})=\left[f_{1}, f_{2}, \ldots, f_{m}\right]^{\mathrm{T}}$.

Alternatively, multiple objectives are frequently reduced to a single-objective problem and optimized by one linear, weighted objective function [119]:

$f(\boldsymbol{X})=w_{1} \cdot f_{1}(\boldsymbol{X})+w_{2} \cdot f_{2}(\boldsymbol{X})+\cdots+w_{m} \cdot f_{m}(\boldsymbol{X})$.

\subsubsection{Design variables}

The main design variables in tolerance-cost optimization are the tolerances $\boldsymbol{t}$. The tolerances are in general 
considered uncorrelated, i.e. independent from each other (see Fig. 7). However, there are also approaches to consider the correlations of the tolerances within the optimization, which is especially relevant in the context of selective assembly [7, 120].

The boundaries for the tolerances are defined by the precision limits of the respective manufacturing machines (see Section 3.2.1). Although the limits do mostly not necessarily have to be set, it makes sense to limit the design space to only technically feasible solutions to minimize the computing time [121]. In addition, the nominal dimensions in combined parameter and tolerance design are considered as design variables [109, 122, 123].

Tolerances are mostly considered as continuous design variables. The restriction to a number of fixed tolerances using discrete tolerance-cost functions necessitates to consider the tolerances as discrete variables in the optimization process. If both discrete and continuous design parameters form the design vector, the problem is called a mixed-discrete problem and makes the optimization more challenging [119].

The complexity further increases with the number of design variables since it leads to a more noisy and multidimensional solution surface [121]. A previous reduction of the number of variables to the relevant parameters influencing cost and quality is useful to shrink the dimensionality of the design space [124].

\subsubsection{Constraints}

In general, the tolerance-cost optimization problem is constrained by at least one inequality condition. It primarily depends on the objective of the optimization if the fulfillment of a quality or a cost limit is expressed by a set of constraints (see Eq. 1). The optimization problem is further extended by additional constraints to consider specific aspects, such as machining and process capacities [125, 126] or stock removal allowance [17].

There are different ways to deal with these constraints within the optimization (see Fig. 7). Using a direct approach, the information of a current solution is only used if all conditions are fulfilled without exception, otherwise it is directly discarded [127]. Thus, this approach leads to slow and inefficient procedures [127]. In contrast, the Lagrange multiplier method transform the constrained in an unconstrained optimization problem using optimality conditions, whereas the penalty method extends the objective function by adding further terms that penalize non-compliance with the conditions [127].

While the penalty and direct approach is independent from the type of the constraints, the mathematical formulation of the Lagrange multipliers can be a challenging task to consider the numerous linear and particularly nonlinear constraints (see Fig. 7) [127]. The realization of these closed-form approaches requires advanced computational and mathematical skills [127].

Not least due to their easier implementation [127], the penalty method in combination with stochastic algorithms is often preferred to the usage of Lagrange multipliers for tolerance-cost optimization.

\subsubsection{Optimization algorithms}

A number of optimization algorithms has evolved over the years and can be classified into deterministic and stochastic algorithms (see Fig. 7) [128]. Traditional optimization algorithms are generally deterministic since they deliver the same results in different optimization runs [128, 129]. Thus, most of these mathematical programming methods are based on the gradients of both objective function and constraints [128].

Numerous researchers proved the suitability of deterministic optimization techniques, e.g. linear programming [50, $72]$, nonlinear programming $[14,105,130,131]$ or integerprogramming $[63,132]$ to solve most basic tolerance allocation problems [9]. However, they reach their limits when tolerance-cost optimization becomes more complex through:

- Sophisticated cost functions [133],

- Sampling techniques in tolerance analysis [12, 91],

- Interrelated key characteristics [134, 135],

- Alternative process selection and stock removal allowance [133, 136, 137],

- Process precision limits and non-overlapping cost curves $[133,135]$ and

- Discrete design variables [135].

As a consequence, more powerful, derivative-free algorithms are required that can problem-independently be applied and do not force the user to oversimplify the optimization problem [39, 138, 139]. Therefore, stochastic algorithms are a suitable alternative to explore the whole, severely constrained design space and to reach the global optimum for multidimensional and -modal problems by the means of trial and error [128, 129, 139]

Despite the randomness of the identified solutions in different runs, most researchers nowadays preferably apply but also enhance both single- and multiobjective, stochastic optimization algorithms for optimal tolerance allocation (see Section 4.1).

Besides well-established algorithms, such as simulated annealing (SA) [3, 66, 134], genetic algorithm (GA) [92, 137, 138, 140], (multiobjective) differential evolution [122, 141, 142], non-dominated sorting genetic algorithm II [143-145], (multiobjective) particle swarm optimization (PSO) [95, 146-148] and ant colony algorithm 
[123], more uncommon algorithms, such as imperial competitive algorithm [149], self-organizing migration algorithm [150], artificial immune algorithm [151], seeker optimization algorithm [152], bat algorithm [153], artificial bee algorithm [154], cuckoo search [155] or teaching-learning based algorithm [156, 157], are used for tolerance-cost optimization. Moreover, hybrid algorithms, a combination of a stochastic and a deterministic or another stochastic optimization algorithm, are studied to improve the optimization results [158-161].

In doing so, numerous publications focus on tolerancecost optimization with the aim to benchmark a newly developed or modified algorithm with other stochastic or deterministic algorithms. Thus, they do not study the different tolerance and cost aspects in detail. However, these studies are often less useful since the results are highly dependent on the algorithm-specific settings which have to be chosen individually. A reasonable choice of one or more termination criteria, such as a maximum number of iterations, total computing time or the achievement of a predefined quality of result, is essential for the identification of the global tolerance-cost optimum (see Fig. 7). Therefore, researchers strive to develop user-friendly algorithms with a small number of required settings to ensure the applicability and reproducibility of the optimization $[156,157]$.

\subsection{Tolerance-cost model}

The main benefit of tolerance-cost optimization compared with other allocation methods lies in the usage of quantitative information about the relation of cost and tolerance (see Section 2.3). For this purpose, a tolerance-cost model is needed to represent the relations between cost and tolerance for several processes and process sequences [72] and thus is a key element in tolerance-cost optimization (see Fig. 7).

Driven by the aim to model these relationships as realistically as possible, tolerance-cost models try to include all relevant cost drivers and their contribution to the resulting manufacturing costs as a function of the assigned tolerances [162].

In addition to their direct impact on the internal manufacturing costs, tolerance allocation further influences numerous internal and external costs incurred in the entire product life cycle [3]. Tolerance-cost models thus cover a wide range of different cost aspects (see Fig. 7), such as costs for assembly and tooling [163, 164], inspection [66, 165], scrap [166], rework [167], rejection [167, 168] maintenance and service [169, 170] or ecological and social costs [171-173]. Their modelling is however complicated by the fact that many costs are not directly measurable [174, 175]. The identification of the costs caused by intangible quality losses, e.g. by decreasing customers' satisfaction or loyalty [174], is challenging, especially since quality loss changes over the product lifetime by product degradation $[175,176]$.

Although the establishment of a practical tolerance-cost model is a tedious and not easy task [14, 177], its efforts are rewarding [43] and seen as a decisive competitive advantage [178] in industrial mass production.

\subsubsection{Manufacturing costs}

The availability of quality empirical tolerance-cost data is an essential prerequisite for the establishment of a reliable tolerance-cost model [107, 178]. Therefore, most studies in literature are based on approximative data from charts and tables published in a small number of textbooks and publications [179-183]. Not least for reasons of industrial confidentiality, the amount of available manufacturing data is strongly limited which is critically recognized in literature [9, 18]. In any case, the general suitability of the tolerance-cost data is restricted since the information is tailored to the manufacturing of specific features by installed and available machines and tools for the different processes [70, 184]. Consequently, the data must fit to the given case to ensure reliable optimization results [178].

The empirical data serves as a basis to identify the correlation between tolerance and cost [177, 178]. In literature, the terms tolerance-cost (or cost-tolerance) curve, function, relationship or relation are synonymously used for the correlation of the cost $C_{i}$ and the tolerance $t_{i}$ or $\delta_{i}$ (see Fig. 10).

The tolerance-cost curve consists of several constant and variable cost elements. The fix costs, e.g. for material, are constant and independent from the chosen tolerance [185]. Nevertheless, they can be of importance in tolerance-cost optimization when selecting the minimum-cost machine from a number of machine alternatives. The machining

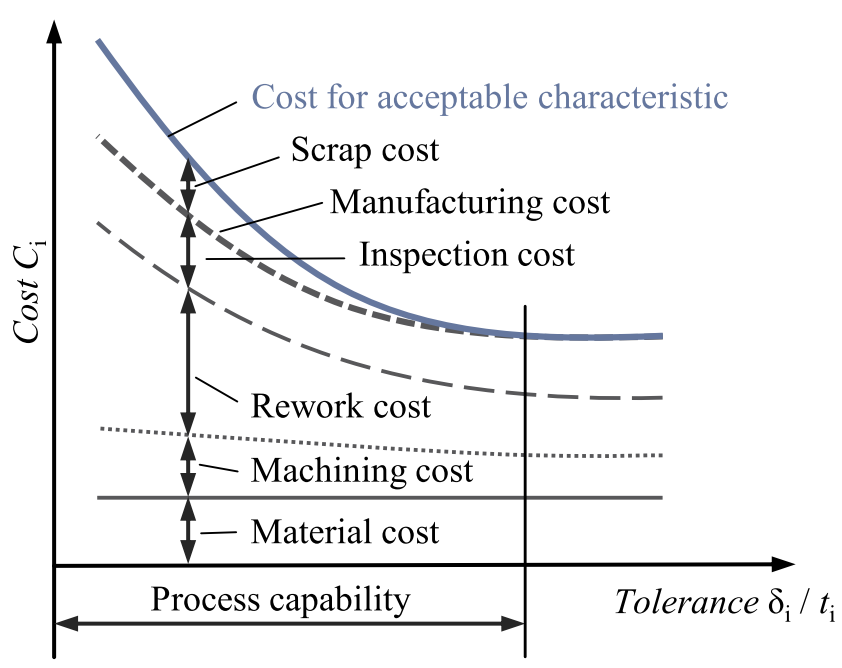

Fig. 10 Tolerance-cost function for a single process based on [185] 
Table 1 Excerpt of common tolerance-cost functions in literature with its coefficients according to Eq. 8 and the resulting function

\begin{tabular}{|c|c|c|c|}
\hline \multirow[t]{2}{*}{ Name } & \multicolumn{2}{|c|}{ Coefficient } & \multirow[t]{2}{*}{ Function } \\
\hline & $m$ & $k$ & \\
\hline Linear & 0 & -1 & $C=a-b \cdot t$ \\
\hline Reciprocal & 0 & 1 & $C=a+b / t$ \\
\hline Reciprocal squared & 0 & 2 & $C=a+b / t^{2}$ \\
\hline Reciprocal power & 0 & $c$ & $C=a+b / t^{c}$ \\
\hline Exponential & 1 & 0 & $C=a+b / e^{t}$ \\
\hline Hybrid & $c_{1}$ & $c_{2}$ & $C=a+\frac{b}{e^{c_{1} \cdot t} \cdot e^{c_{2} \cdot t}}$ \\
\hline
\end{tabular}

For more information and references, see [9, 18, 178]

costs vary with tolerance since the manufacturing of more accurate parts requires more precise tools or additional manufacturing operations, adjustment of the processing parameters, e.g. lower process rate, or particular care of the manufacturer [167, 185]. Furthermore, tighter tolerances increase the number of parts to be reworked, cause higher inspection costs to ensure their measureability and lead to a higher number of scrap parts and costs [185].

Depending on the data, different types of regression functions are suitable to derive continuous tolerance-cost function with acceptable fitting errors [45, 75, 177]. As a consequence, a number of traditional- and non-traditional, linear and nonlinear functions were presented in literature over the years (see Fig. 7) [9, 178]. The most relevant and frequently used functions in literature [178] can suitably be described by a generalized tolerance-cost function according to [144]:

$C_{i}\left(t_{i}\right)=a_{i}+b_{i} \cdot e^{-m \cdot t_{i}} \cdot t_{i}^{-k}$

Thus, a number of linear and non-linear tolerance-cost functions with two up to four parameters can be expressed by the proper determination of the coefficients $m, k$ (see Table 1).

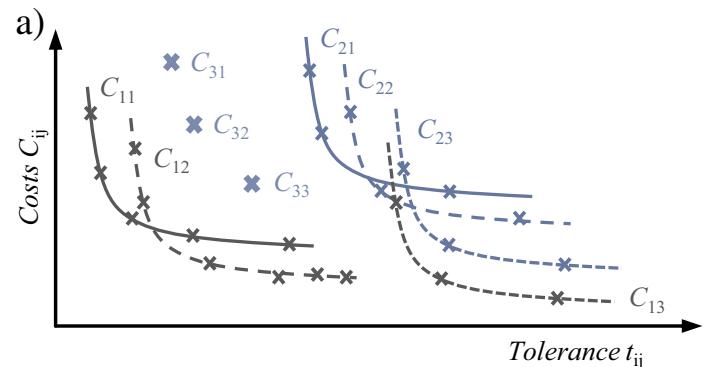

Combinations of these approaches, e.g. the linear and the exponential function

$C=a+b_{1} \cdot t+\frac{b_{2}}{e^{t}}$

or the reciprocal power and the exponential function

$C=a+\frac{b_{1}}{t^{c_{1}}}+\frac{b_{2}}{e^{c_{2} \cdot t}}$,

as well as third- and higher-order polynomial functions

$C=a+b \cdot t+c \cdot t^{2}+d \cdot t^{3}+\ldots$

are occasionally used to reduce model uncertainty [75].

However, a proper application of analytical functions requires a reasonable selection of the model type and determination of the coefficients with respect to the given data $[54,145,186]$. Motivated to overcome this limitation, advanced approaches based on fuzzy and artificial neural networks [141, 145, 162, 177, 187, 188] have been developed to establish tolerance-cost functions without predefining the form of the curve by choosing a specific function [162].

Nevertheless, analytical functions with less coefficients are often preferred because they are easier to optimize, especially if gradient-based optimization algorithms are applied [75, 178, 188]. Exponential and polynomial functions and more sophisticated models, in contrast, approximate the curves with a higher accuracy $[75,189]$ but the objective function becomes more complex to be solved by optimization.

Moreover, discrete data is directly used in tolerancecost optimization to avoid uncertainty from the choice of model type and its coefficients [186]. In addition to manufacturing, discrete tolerance-cost functions are used to address external supply in combination with alternative supplier selection [190, 191] or make-or-buy decisions (see Fig. 11a) [192]. However, besides the great amount of data, optimization algorithms handling discrete variables are required to solve the optimization problem correctly [38].

Traditionally, the tolerance-cost function is a function of dimensional and rarely of geometrical tolerances [193].

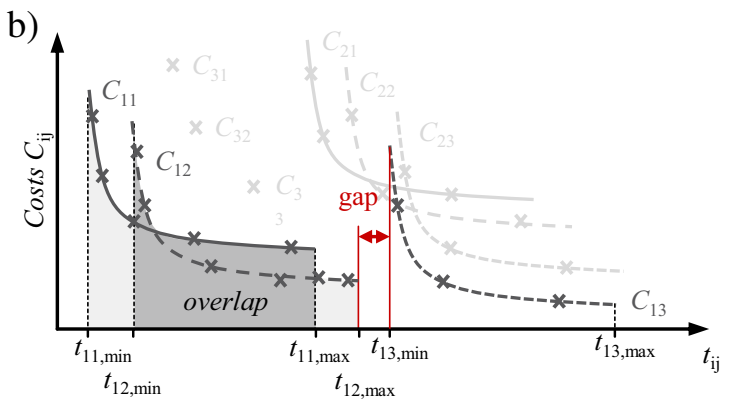

Fig. 11 Tolerance-cost model: a mapping of manufacturing costs using tolerance-cost functions and external supply with discrete tolerance classes, b gaps and overlapping areas 
Alternative approaches substitute the tolerance as an input by the variance [104], process procession [194] or process capability indices $[92,195]$ to enhance the informative value of the tolerance-cost curves. This enables the consideration of further important aspects from serial production, e.g. discontinuous cost functions with a sharp increase in costs through a $100 \%$-inspection if a specified process capability limit is not fulfilled [13].

However, most of the aforementioned aspects are not rigorously considered if the tolerance-cost models are just a means to an end. Thus, tolerance-cost functions and its parameters are often only arbitrarily chosen in literature, neglecting relevant manufacturing issues [178].

Since a number of tolerances is optimally allocated in tolerance-cost optimization, at least one tolerance-cost function is needed for each individual tolerance $t_{i}$ to define the total tolerance-cost model $[64,101]$ :

$C_{\text {sum }}(\boldsymbol{t})=\sum_{i=1}^{I} C_{\mathrm{i}}\left(t_{i}\right)$,

$t_{i, \min } \leq t_{i} \leq t_{i, \max }$.

So far, Eq. 12 is valid if only one machine per tolerance $t_{i}$ is available. However, the selection of a cost-optimal machine realized by the most cost-effective machine alternative $j$ is of particular importance in the industrial manufacturing environment (see Fig. 11a) [196, 197]. Mathematically spoken, the tolerance-cost model considering alternative process selection is defined as:

$C_{\text {sum }}(t)=\sum_{i=1}^{I} \sum_{j=1}^{J_{i}} x_{i j} \cdot C_{i j}\left(t_{\mathrm{i}}\right)$,

$\sum_{j=1}^{J_{i}} x_{i j}=1$ with: $x_{\mathrm{ij}} \in\{0 ; 1\}$,

$t_{i j, \min } \leq t_{i j} \leq t_{i j, \max }$

while the selection parameter $x_{i j}$ is used to choose a production machine/process to realize the tolerance $t_{i}[63$, 109]. Achieving a least-cost design, the minimum-cost machine is selected with the aid of a total minimum-cost curve of all machines with respect to their individual process limits $t_{i j, \min }$ and $t_{i j, \max }[36,100]$ or the usage of mixeddiscrete optimization techniques [117]. Besides the number of tolerances and available process alternatives, tolerancecost optimization is further complicated by regions of nonoverlapping, non-feasible solutions in the total tolerancecost model (see Fig. 11b) [17, 99].
For a single-stage process, the design tolerance $t$ corresponds to the process tolerance $\delta$. In reality, multiple manufacturing steps are generally needed to realize the design tolerance $t_{i}$ and the manufacturing costs for the sequence of multi-stage processes are considered by one tolerance-cost curve [50, 198]. Optimizing both design and manufacturing tolerances simultaneously, the tolerance-cost model of Eq. 13 further extends to:

$C_{\text {sum }}(\delta)=\sum_{i=1}^{I} \sum_{j=1}^{J_{i}} \sum_{k=1}^{K_{i j}} x_{i j k} \cdot C_{i j k}\left(\delta_{\mathrm{ijk}}\right)$,

$\sum_{k=1}^{K_{i j}} x_{i j k}=1$ with: $x_{\mathrm{ijk}} \in\{0 ; 1\}$,

$\delta_{i j k, \min } \leq \delta_{i j k} \leq \delta_{i j k, \max }$

while the machine selection parameter $x_{i j k}$ is used to choose the best production machine $k$ for each process $j$ to realize the tolerance $\delta_{i j}[17]$.

\subsubsection{Quality loss}

Traditionally, it is assumed that as long as deviations from the target value of a $\mathrm{KC}$ are within predefined limits, they do not influence the customers' awareness of quality [16]. In doing so, the quality loss for the customer is neglected since non-optimal products are perceived as products of same quality [16]. Only non-conformance is assumed to be critical and is considered in tolerance-cost optimization in terms of scrap or rework costs (see Fig. 12a). However, TAGUCHI's basic idea of quality loss provoke a paradigm shift in the perception of quality. Any deviation from the optimum target value is noticed by the customer as a loss of quality (see Fig. 12b) [32].

As a consequence, product quality can only be improved by incorporating the customer into optimal tolerance allocation [16, 32]. As a result, the quality loss has successively been integrated in the framework of tolerance-cost optimization over the years-in literature often discussed under the term of robust tolerance design. Hence, quality loss can most easily be described by a symmetrical, quadratic quality loss function:

$L(Y)=k \cdot(Y-m)^{2}$

to estimate the monetary loss $L$ in dependence of the systems response $Y$ and its target value $m$ [16]. The quality loss coefficient $k$ must be assigned with respect
Fig. 12 Customer's perception of quality: a equally good quality vs. b loss of quality based on [16]
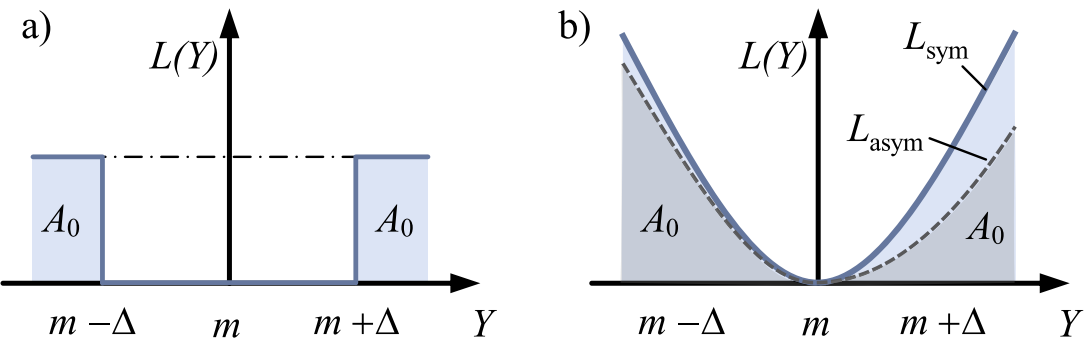
to the given case. However, the identification of suitable quality loss coefficients can be crucial since the quality perception is both customer- and product-specific [16, 32]. Driven by the global aim of a realistic representation of the mostly intangible loss of quality, numerous analytical functions for the symmetrical and asymmetrical nominalthe-best, smaller-the-better larger-the-better case have been developed and integrated in least-cost tolerance-cost optimization (see Fig. 7) [33, 34, 53, 170, 175, 176, 199-208]. The quality loss functions were further adapted to different probability distributions, e.g. to the folded normal [209], trapezoid and triangular [210] or Weibull probability distribution [199] or alternatively expressed by fuzzy modelling [192, 211-213].

However, by additionally incorporating the customers' expectation of quality into the optimization framework, the cost-quality dilemma is further intensified [214] since a balance between the manufacturing costs and quality loss must be struck [32]. Consequently, this leads to the fact that two conflicting objectives are concurrently optimized in least-cost tolerance-cost optimization. Either they are previously weighted and considered in one singleobjective function $[34,126,215]$ or they are optimized by multiobjective optimization algorithms creating a set of non-dominated solutions (see Section 3.1.1) [143]. Multiple, interrelated KCs thus function as dependent objectives and their correlations have to be considered in optimization [15, 216, 217].

\subsection{Technical system model}

Since it is the global aim to optimally allocate the tolerances for a newly or (re-)designed product, the representation of the technical system with its individual components is an important issue in the tolerance-cost optimization process (see Fig. 8). In general, any system under variations, which have a significant influence on the system behaviour and have to be limited by suitable tolerances, can be optimized. The size and complexity of the technical systems range from small assemblies with a manageable number of components and tolerances up to whole assemblies with multiple parts and sub-assemblies. Besides the optimization of mechanical systems, products of other disciplines are also in focus, such as electrical networks [76, 84, 88, 116, 218, 219], optical devices [220, 221] or chemical and pharmaceutical processes [222-225]. Therefore, the relevant key characteristics are often nongeometrical (see Section 3.3.1) and the tolerances are allocated to non-geometrical parameters (see Section 3.3.8). The subsequent discussion is however limited to mechanical systems.

With the aim to analyze the system of interest, it must be represented by a suitable model. By making assumptions, simplifications and neglectibilities the system becomes manageable in tolerance analysis. Therefore, the decision of the right level of detail to model a realistic system behaviour can become a challenging task since it influences the optimization process with respect to computation time and quality of results.

\subsubsection{Key characteristics}

Although technical systems primarily serve to fulfill a function in use, they must meet a number of different quality requirements. Therefore, the requirements are converted into geometrical requirements and expressed by a set of (functional) key characteristics (F)KC as measures of quality (see Section 2.2) [57].

The geometrical (F)KC, also known as assembly response function [60], is mathematically expressed by a geometrical measure. In addition, the effect of geometrical part deviations can directly be mapped on non-geometrical KCs by a function of tolerances but also of additional variables such as nominal dimensions and non-geometrical parameters (see Section 3.3.8). In the case of the car brake, the angle of the brake disk and the brake pads function as a geometrical key characteristic, while the performance of the system could further be described by the brake potential as a function of the brake angle [189].

The quantification of the $\mathrm{KC}$ is generally a complex task $[19,226]$ since it requires a good product expertise [227] or the correlations of part deviations and the resulting quality are simply not directly known (see Section 3.4) [228]. Hence, it is necessary to derive the $\mathrm{KC}$ functions by gathering information from simulations and experiments and transforming them in mathematical functions and surrogate models.

Moreover, it is quite common to further differ between linear and nonlinear $\mathrm{KC}$ functions (see Fig. 8). The type has a significant influence on the choice of the tolerance analysis model with its different aspects (see Section 3.4) and the definition of the optimization problem in combination with the selection of a suitable optimization algorithm (see Section 3.1).

In this context, increasing product complexity leads to the fact that multiple KCs represent the total quality of a product in accordance with the KC-flowdown [57, 229]. Depending on the correlation of the KCs (see Fig. 8), they can either be called simple, since they are independent from each other, or they are interrelated, because they are or connected by mutual elements and can conflict $[9,72,73$, 229]. As exemplarily illustrated in Fig. 13, the gaps between the brake disk and the pads $Y_{1}$ and $Y_{2}$ are interrelated by the distance of the brake disk $X_{4}$ :

$Y_{1}=X_{4}-\left(X_{1}+X_{2}+X_{3}\right)$ 


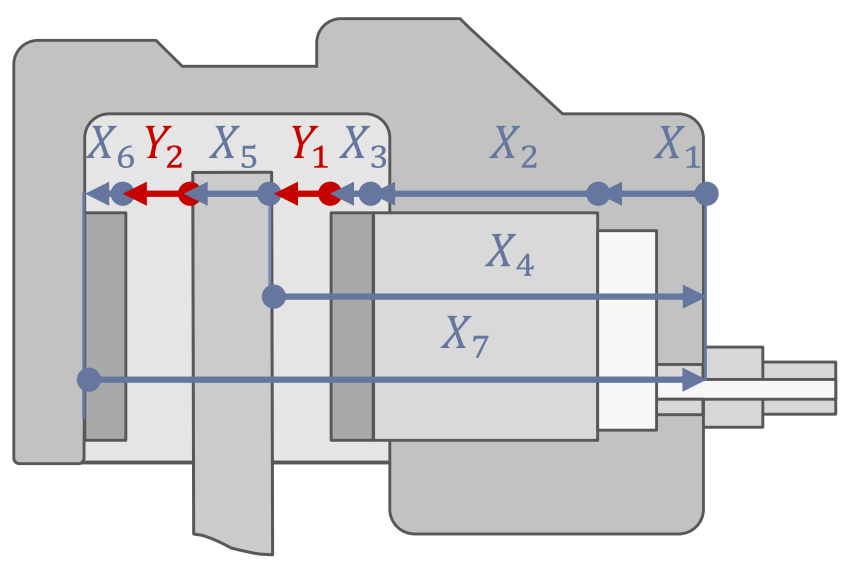

Fig. 13 Car brake system: interrelated key characteristics

$Y_{2}=X_{7}-\left(X_{4}+X_{5}+X_{6}\right)$

Although existing design methods help to create a robust design by de- and uncoupling the KCs [230], they cannot completely be eliminated [229] and have to be considered in tolerance-cost optimization. As a consequence, the number of $\mathrm{KCs}$ and their correlation mainly influence the optimization problem and its solution procedure, especially the handling of multiple constraints in terms of establishing non-iterative, closed-form solutions by Lagrange multipliers $[15,65,99,231-234]$ and their proper consideration in tolerance evaluation and scrap rate estimation [235]. Over the years, various publications addressed the integration of multiple FKCs in the framework of tolerance-cost optimization, e.g. [15, 65, 99, 231-238].

\subsubsection{Dimensionality}

In order to model the technical system, the dimensionality of the system is decisive for a realistic tolerance analysis (see Fig. 8) [39]. If the KC can be described by a linear tolerance chain to consider only dimensional tolerances, it is sufficient to reduce the problem to a $1 D$-problem. The tolerance analysis of nonlinear KCs and geometrical tolerances often require a geometrical $2 D$ - or even $3 D$-model $[39,239]$. As a consequence, the dimensionality influences the tolerance analysis approach with its mathematical model (see Section 3.4.3) and the optimization process. However, it always depends on the effects to be considered and the dimensionality that has to be chosen as a compromise of model accuracy and computational effort.

\subsubsection{Assembly type}

In mechanical engineering, the development of a technical system generally corresponds to the process of designing an assembly consisting of various parts contributing to the overall system functionality. With respect to how the parts are assembled, systems can be classified into two different types [229]. The assembly process of a Type-1-assembly is typically part-driven since the system is exact constraint by the pre-fabricated mates positioning the different parts with respect to the others [229]. Focusing on the car brake from Fig. 1, the disk is put on the wheel hub which locates the disk by its mates [229]. In contrast, the assembly of a Type-2-assembly, e.g. a car door, requires fixtures for firstly defining the positions of the individual parts with the help of locators by temporarily locking the open degrees of freedom [229]. Secondly, the positions of the parts are fixed by joining the parts together by a joining operation such as welding, riveting or clinching [229].

As a consequence, the KC deviation of an Type-1assembly is a direct result of the individual part deviations, whereas the total assembly process with its multiple, additional deviations mainly contributes to the overall deviation of the KC of a Type-2-assembly [229]. Several multi-station assembly steps with different manufacturing processes are required for the process-driven assembly of even small systems. Thus, the in-process deviations flow like a stream of variations over the different assembly stations [240]. Hence, tolerance-cost optimization of Type2-assemblies is strongly related to the optimal selection of process parameters, optimal fixture layout design and the optimization of assembly and joining sequences for the realization of over-constrained systems of numerous compliant parts [18, 144, 164, 169, 241-244].

Accordingly, the focus of tolerance-cost optimization literature strongly depends on the assembly type of interest (see Fig. 8). Thus, an initial classification of the type is helpful to identify the scope and to make clear which aspects are most relevant.

\subsubsection{Structural behaviour}

In general, technical systems are often assumed to be rigid in tolerancing. Even if the compliance influences the KCs, which is especially relevant for Type-2-assemblies consisting of multiple, compliant sheet parts (see Section 3.3.3), this fact is often neglected in tolerance-cost optimization. Although several authors strive to integrate compliance in tolerance-cost optimization, especially in context of process-oriented tolerance-optimization [241, 244-247], mostly just simple cases are considered whose structural behaviour is approximated by simple analytical equation. If the system gets more complex, the use of finite element simulation in combination with meta modelling methods is favoured, primarily for reasons of computing time [246, 248-250]. Thereby, non-geometrical influence parameters play an important role and the tolerance expert has to identify, if their variations influence the compliance and 
thus the functionality of the system or if they can be assumed to be constant (see Section 3.3.8) [250].

\subsubsection{Statical determinacy}

The basic principle of a clear and robust design is to create an isostatic, exact constraint system ensuring a robust and predictable product functionality. Thus, each degree of freedom should exactly be constrained once [251]. Structured procedures based on screw theory [229] or socalled Schlussartenmatrizen [252] prevent the designer to mistakenly break this basic rule [229] prior to the parameter and tolerance design.

In reality, there are different reasons to consciously deviate from an exact constraint design. With the primary goal to increase system rigidity parts are often redundantly constrained several times by multiple fixing thus leading to over-constrained or also called hyperstatic systems [229, 253]. Thus, thermal or mechanical influences lead to stress and non-negligible part deformations significantly influencing the KCs [229]. As a consequence, additional information of finite element analysis is needed for the prediction of the geometrical part variations [229].

Besides, gaps between parts are purposefully added for function or used as clearances to ensure assemblability [229, 254]. In doing so, the system becomes under-constrained since some degrees of freedom are left open and thus the positions and orientations of individual parts in an assembly are not exactly defined [229]. Additional information is thus needed to compensate the uncertainty of part positions and to make the problem evaluable in tolerance analysis. Therefore, the unknown part locations can either be modelled probabilistic or deterministic by considering forces from assembly or gravity or identifying worstcase positions with the aid of additional optimization approaches [254-259].

Studies on tolerance analysis of statically indeterminate assemblies are gaining more importance in the last years, whereas their findings are just rarely transferred to tolerance-cost optimization [260] and mostly neglected. The fact that the status of constraintness can change under variation and over time [229] further complicates the analysis and optimization of these systems.

\subsubsection{Mobility of systems}

Besides static systems, systems in motion have arisen the interest of various research activities (see Fig. 8) [98, $118,122,234,261-265]$. If the total movement behaviour or parts of a defined motion of a kinematic system are relevant for its functionality, such as for the accuracy of motion over a period of time [98], the KCs are optimized as function of time for a whole motion with respect to a discrete time step $i$ (see Section 3.3.7). Thus, the KCs are analyzed for each time step $i$ and the time-variant results are evaluated according to a predefined quality criterion (see Section 3.4.5) within each optimization step (see Fig. 6) [98, 234]. However, depending on the type of the KCs and the system behaviour, the analysis can often be reduced to one discrete point in time. If selected positions of a time-dependent system are of interest, e.g. the initial or the final position of a mechanism, it is sufficient to only consider these points in time in the tolerance analysis to reduce the computation time. Moreover, dynamic aspects such as inertia can be considered by coupling tolerance-cost optimization with multi-body simulations to describe the dynamic system behaviour under motion $[122,266]$.

\subsubsection{Time dependency}

If the status of system changes over time, the time-variant KCs are described by a function of time $\tau$ and are solved for a number of time steps $I$ to ensure the quality fulfillment for a predefined time period [98, 118]:

$\hat{Q}(\tau)=\left[\hat{Q}\left(\tau_{1}\right), \ldots, \hat{Q}\left(\tau_{I}\right)\right]^{\mathrm{T}} \forall Y_{i}$ with $i=1, \ldots I$.

As exemplarily shown in Fig. 14, the angle $\gamma$ between the brake disk and the brake pads influencing the clining pressure of the brake disk is analyzed for a whole rotation to consider the radial run-out and wobbling of the disk discretized by $I$ time steps.

However, the $I$-times evaluation of the KCs in each optimization results in long computation times, especially for the application of sampling-based tolerance analysis and stochastic optimization algorithms (see Sections 3.1.4 and 3.4.4). Thus, the identification of the critical points in time are decisive for the evaluation of the quality of the product. Besides systems in motion (see Section 3.3.6), the consideration of short-time and long-time variant effects, such as wear or part deformations by varying loads, require a time-variant description of the KCs to cover the entire lifetime of a product [98].

\subsubsection{Influences}

In addition to the nominal geometrical parameters and its tolerances, non-geometrical internal and external influences on the KCs can also be in focus (see Fig. 8), such as temperature, forces, torques, gravity, loads or material properties, e.g. density, modulus of elasticity or thermal expansion coefficient $[5,98,267-270]$. Thus, it is a critical task to asses which influence parameters are relevant and have to be considered within the tolerance-cost optimization and to what extent. However, it is always case-specific and depends on the type of technical system and its purpose 
of use. In the case of the car brake system, the material properties for example strongly influences the braking performance in addition to the geometry.

In doing so, these parameters can be considered as constant or variable to be additionally optimized, also under the presence of uncertainty in context of robust tolerance design [98, 268]. Thereby, their effects on the KCs are either described by elementary analytical equations, e.g. the linear thermal expansion law, or derived from the results of experiments and simulations, which are often indirectly integrated in the $\mathrm{KCs}$ by surrogate models to reduce the computational effort [98, 267, 271, 272].

\subsection{Tolerance analysis model}

Tolerance analysis plays an important role in tolerance-cost optimization since it is used to analyze the technical system under variation (see Section 3.3) and to check the fulfillment of the requirements defined by the KCs (see Section 3.3.1). Thus, the efficiency and the results of the optimization strongly depend on the tolerance analysis model with its subsequently discussed aspects (see Fig. 8) [273].

\subsubsection{Tolerance specification}

As shown in Fig. 4, tolerance-cost optimization is based on a predefined tolerance specification [58]. Therefore, structured procedures as well as software tools assist the designer in the correct specification of dimensional and geometrical tolerances according to the current standards of ISO and ASME [58, 274-276]. Even if tolerance specification and analysis frequently address both geometrical and dimensional tolerances (GD\&Ts), tolerance-cost optimization is mostly limited to dimensional tolerances (see Section 4.1).

\subsubsection{Concurrent tolerance design}

The general objective of optimal tolerance allocation differs from its application in design or manufacturing (see Section 2.1). The designer allocates design tolerances to the final part geometry features ensuring product functionality, whereas the manufacturer deals with the issue how to realize the defined design tolerances in manufacturing [4, 46]. Accordingly, each design tolerance has to be transformed in a set of manufacturing tolerances for a sequence of process operations [277]. In doing so, tolerances are sequentially defined for a different reason, for product functionality or for manufacturability [17].

In context of concurrent tolerance-cost optimization, both disciplines are combined and the design tolerance is considered as a sum of individual machine tolerances under the consideration of a sufficient stock removal allowance [17].

In doing so, the basic idea of tolerance balancing is integrated in the tolerance-cost optimization framework and manufacturing tolerances are optimally allocated with respect to product functionality [3].

Besides, the optimization of tolerance values for nongeometrical parameters, e.g. for temperature or loads, is addressed in robust tolerance design (see Section 3.3.8) [277].

\subsubsection{Mathematical model}

The representation of the individual part deviations within their limiting tolerance ranges is a key element in tolerancing since it serves as a basis to predict their influence on the KCs [226, 278]. In general, tolerance-cost optimization is not restricted to a specific mathematical model (see Fig. 8). However, it influences the tolerance analysis procedure and thus indirectly the optimization process in terms of its results and computing times. As a consequence, the tolerance expert should thoroughly choose the mathematical model with respect to the given technical system model and reasonable assumptions.

In most cases, vector loops with comparatively low computing times are sufficient for the optimization of simple, rigid assemblies with few components and dimensional tolerances. If commercial CAT-software is integrated in the optimization framework (see Section 3.4.4), the representation of the geometrical deviations are mostly represented by variational models based on the nominal CAD-model
Fig. 14 Car brake system: time-variant $\mathrm{KC}$ for a system in motion
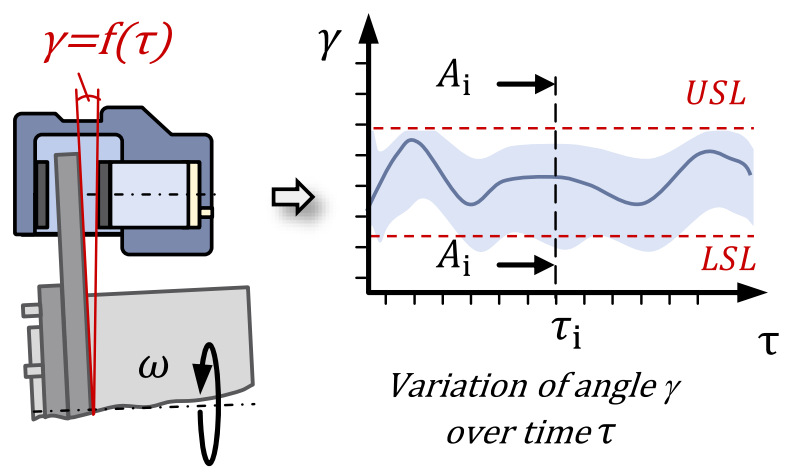
geometry [78, 198, 279, 280]. Besides, the application of polytopes [281] and torsor models [282-284] can occasionally be found in literature.

\subsubsection{Tolerance evaluation}

Tailored to the specific academic and industrial needs, a variety of worst-case and statistical approaches for tolerance evaluation have been developed over the years [ 60 , 226, 285] (see Fig. 8). Especially in the early years of tolerance-cost optimization, worst-case approaches were quite popular to ensure a $100 \%$-fit of the specification limits $[96,101,102,105]$. Despite their unrealistic claim of a full acceptance [64, 71], they are still used since most designers are familiar with the easily applicable approach $[60,82]$. Since the computational effort is similar to the most statistical methods but lead to tighter tolerances and consequently to higher manufacturing costs, they are increasingly losing importance. Rather, they are sensibly used for an initial estimation today [82].

Statistical approaches mitigate this unrealistic claim of a worst-case scenario by accepting a small percentage of nonconformance [286]. In doing so, the probability of each part deviation within their associated tolerances are considered in tolerance analysis [71, 286]. A number of statistical approaches were established for tolerancing and are frequently applied in tolerance-cost optimization, e.g. the root sum square method [32, 99, 137, 287], different variants of estimated mean shift methods [142, 207, 288, 289] and the Hasofer Lind reliability index [38, 85] (see Fig. 8).

Especially in times when deterministic optimization techniques were preferred, numerous authors studied the handling of the constraints by Lagrange multipliers with respect to the different approaches for tolerance analysis [45, 64, 101, 131, 234]. However, in most modern articles, the decision for a specific method is not made consciously but rather randomly in context of tolerance-cost optimization. Their integration in tolerancecost optimization became scientifically less interesting with the emergence of stochastic optimization algorithms.

Besides, the usage of sampling techniques for statistical tolerance analysis is quite popular, especially in industry. Since they do not need to linearize KC functions and can consider any distribution [285], they are problemindependently applicable [290] and reflect a more realistic interpretation of part manufacturing and assembly [18, 194]. Driven by these benefits, sampling-based tolerance analysis software has successively been developed and was consequently integrated in the optimization framework, e.g. Sigmund $^{\circledR}$ [291] eMTolMate ${ }^{\circledR}$ [279], RD\&T [173, 292294], VisVSA ${ }^{\circledR}[30,78]$ and $3 \operatorname{DCS}^{\circledR}[249,295,296]$. However, the principle of randomness leads to a noisy, non-deterministic system response which complicates the application of gradient-based optimization algorithms [297299]. More sophisticated approaches are required to estimate the gradient information [131, 273, 297, 298, 300]. Therefore, stochastic optimization algorithms are preferably applied to overcome this problem since they do not need any gradient information and can properly handle the stochastic inputs (see Section 3.1.4). In this context, the Monte Carlo sampling, e.g. applied in [78, 118, 235, 260, 301] is frequently chosen for tolerance-cost optimization while alternatives, e.g. the Latin hypercube sampling $[12,302]$ or the Hammersley sequence sampling [222], are just rarely addressed. Thereby, the increasing computer powers enable the handling of huge sample sizes $n$ which are necessary to get a reliable prediction of the probabilistic system response [12]. As a consequence, the function for each $\mathrm{KC}$ must be evaluated $n$-times in every iteration (see Fig. 6). Consequently, the usage of the computationally intensive sampling techniques with suitable large sampling sizes in combination with stochastic optimization algorithms require comparatively large time effort for the optimization approach $[62,70,106]$. Thus, optimization with increasing sample sizes over the optimization progress reduces the computational effort while achieving reliable results $[155,260]$.

\subsubsection{Quality metric}

After the application of an tolerance evaluation technique, its results are assessed by a suitable quality metric to check if the assigned tolerances can fulfill the predefined quality requirements (see Fig. 8). The choice of quality metric depends on the chosen evaluation technique in combination with the definition of quality [12].

Using sampling techniques, the system response $Y$ is calculated for all individual samples. As exemplarily shown in Fig. 15, the resultant probability distribution serves as

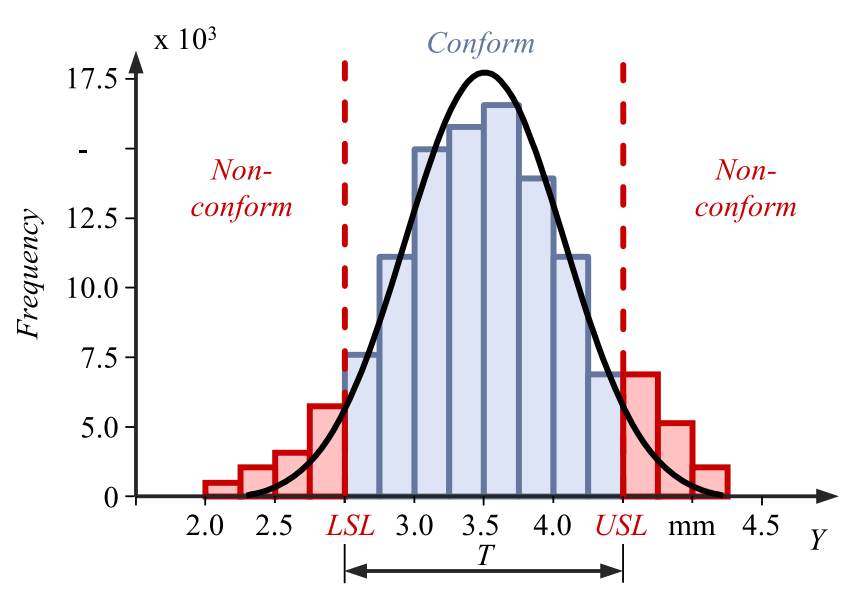

Fig. 15 Conformance and non-conformance defined by the upper and lower specification limits 
the basis to determine the yield as the number of samples, which are in the acceptance range between the lower and upper specification limits $L S L$ and $U S L$ [12]. Thus, the yield is decreased by the non-conform samples failing the specification limits [12]. The non-conformance rate $z$ is thus expressed in parts-per-million in accordance with the philosophy of Six Sigma [303].

Even if the terms non-conformance rate [144, 260], scrap rate [12, 98], defect rate [304, 305] or rejection rate $[88,94]$ are not exactly synonymous, they are often used simultaneously in this context to define the percentage of samples which do not lie within the specification limits. The yield is calculated by the integral over the probability distribution $\varrho$. Subsequently, the non-conformance rate $\hat{z}$ is compared with the specified, maximum conformance rate $z_{\max }$ and functions as a constraint in least-cost tolerancecost optimization $[12,118]$ :

$\hat{z}(t)=1-\int_{L S L}^{U S L} \varrho(Y(t)) d x \leq z_{\max }$.

If the distribution type $\varrho$ is known, the cumulative frequency distribution can be used to calculate or rather predict the resultant (non-)conformance rate $\hat{z}$ [12]. Otherwise, distribution-independent estimation procedures are required [12]. Thus, the choice of a suitable estimation technique in combination with the sample size is decisive to avoid over- as well as underestimations of the (non)conformance rate since they cause the allocation of either unnecessary tight or unacceptable wide tolerances [12].

In contrast to sampling techniques, convolution-based approaches are tailored to an idealized distribution of the resultant KC. The root sum square equation, for instance, assumes that the $\mathrm{KC}$ corresponds to a centred standard normal distribution. Thus, it determines the tolerance range $T_{\mathrm{RSS}}$ for a $99,73 \%$ yield $(\widehat{=} \pm 3 \sigma)[285,303]$. In doing so, the conformance rate is indirectly checked by comparing the evaluated tolerance range $T_{\mathrm{RSS}}$ with the specified acceptable assembly tolerance $T_{\mathrm{RSS}, \max }=U S L-L S L$ [285]:

$T_{\mathrm{RSS}}=\sqrt{\sum_{i=1}^{I}\left(\frac{\partial f}{\partial X_{i}}\right) t_{i}{ }^{2}} \leq T_{\mathrm{RSS}, \max }$.

In accordance with statistical process control for series production, capability indices are also used to measure the quality fulfillment [195, 269, 279]. In context of robust tolerance design, the variance serves as a measure for the sensitivity of the system $[80,306]$.

\subsection{Computer-aided systems for tolerance-cost optimization}

Besides the development of the method, several authors concentrated on the integration of tolerance-cost optimization in the virtual product development environment using the functionalities of CAD-systems for product geometry representation and extending their functional scope [113, 283, 307-310]. In comparison with CAT-software for tolerance analysis, the integration of additional optimization modules and information basis of manufacturing knowledge are essential to assist the designer in the (semi-)automatic process of tolerance-cost optimization [46, 134, 197, 308, 311-314]. Hence, specific expert systems were developed for optimal tolerance allocation with the aim to cope with the complexity and to provide applicable, efficient and user-friendly software tools avoiding simulation code to be written [46, 76, 134, 197, 313, 315]. However, commercial stand-alone software programs for tolerance-cost optimization are not established yet. In most cases, suitable CAT-software modules are combined with optimization tools (see Section 3.4.4).

\section{Tolerance-cost optimization through the ages}

Already in the early years of tolerancing, the impact of tolerances on quality and cost was addressed by optimal tolerance allocation. Traditional approaches were gradually substituted by optimization-based methods from the middle of the twentieth century up to modern days. Thus, the interest in tolerancecost optimization has steadily grown and is reflected in the number of current research activities (see Fig. 16). A review on more than fifty years of research in the field of tolerancecost optimization is presented in the following and serves as a basis to identify current drawbacks and future trends.

\subsection{Historical development}

Driven by the efforts and findings of numerous research activities, the method has constantly evolved over the years.

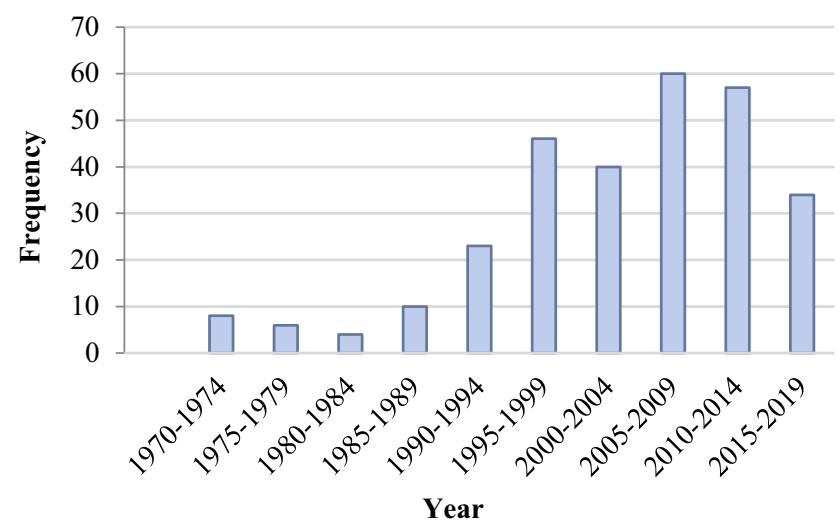

Fig. 16 Tolerance-cost optimization through the ages: number of publications focusing on tolerance-cost optimization from 1970 to 2019 
While at the beginning, its fundamentals were studied, current research activities can make use of them and focus on specific partial aspects of the key elements (see Section 3). As a consequence, the tolerance-cost models are further enhanced, the technical system can be modelled and analyzed in a more realistic way and the optimization procedures are improved in terms of efficiency, accuracy and applicability. With the aim to represent the change and development through the ages, 290 publications were studied and analyzed with respect to the key elements of Figs. 7 and 8. Therefore, the subsequent discussion focuses on a selection of the most relevant categories and their change over the years which is illustrated in Fig. 17. A detailed list of the considered publications can be a) Optimization algorithms

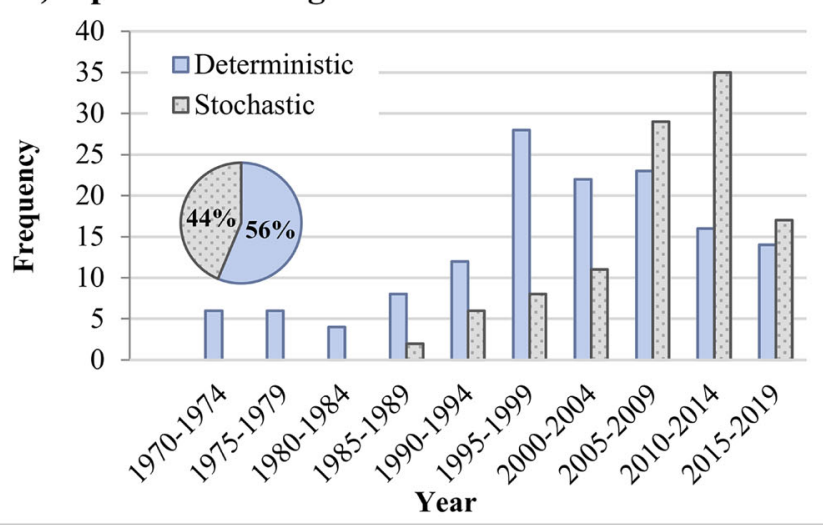

c) Quality Loss

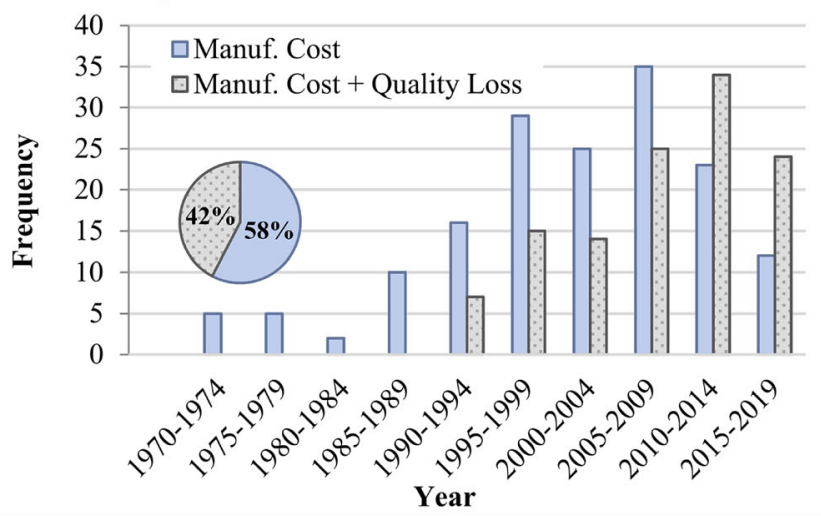

e) Tolerances

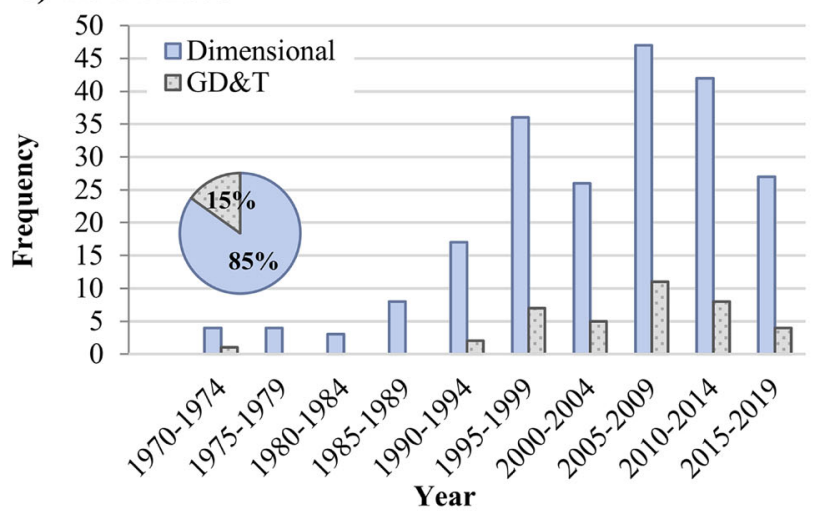

Fig. 17 Tolerance-cost optimization through the ages: a historical review on distinctive aspects from 1970 to 2019: a applied optimization algorithms, b consideration of manufacturing tolerances,

\section{b) Concurrent tolerance design}

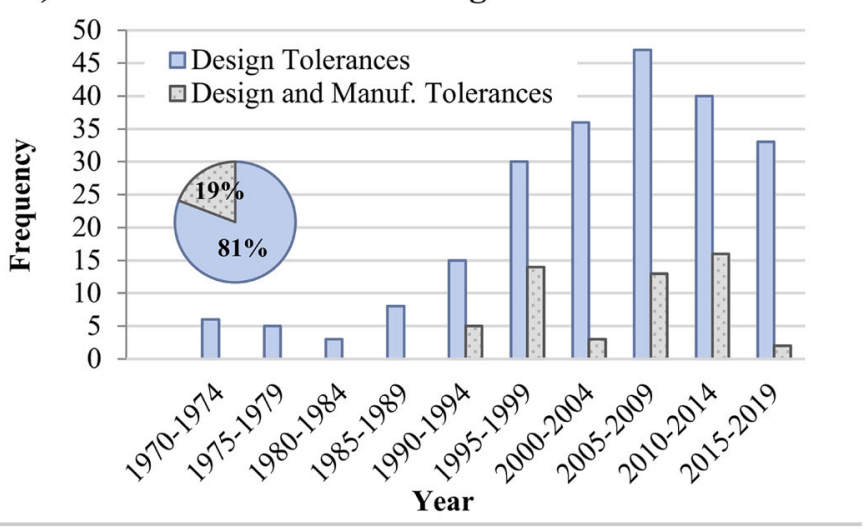

\section{d) Dimensionality}

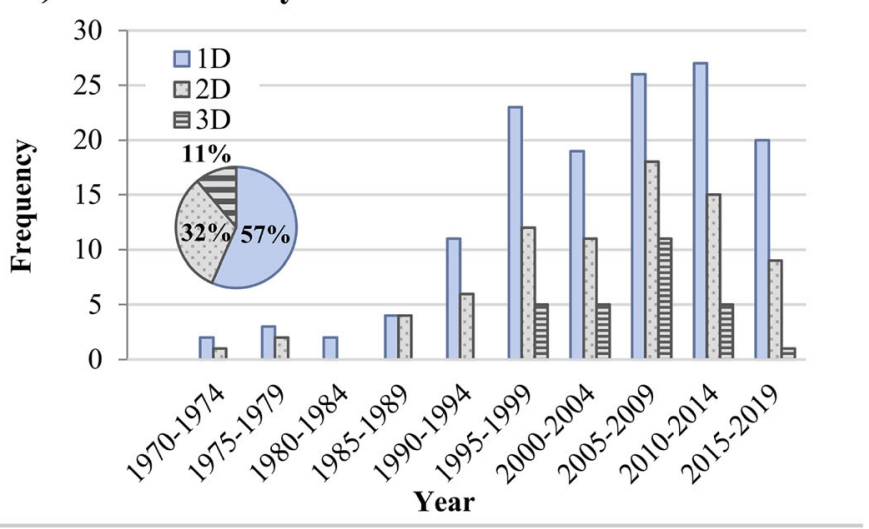

\section{f) Tolerance evaluation}

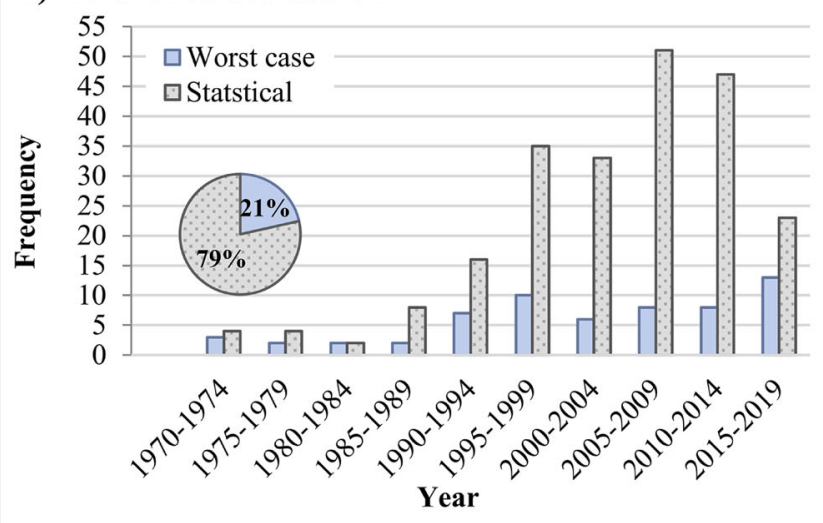

c incorporation of quality loss, $\mathbf{d}$ dimensionality of studied systems, e type of tolerances, $\mathbf{f}$ applied tolerance evaluation methods 
found in the Appendix in Table 2. The assigned keywords emphasizes the main focus of the individual contributions.

Optimization algorithms In early years, the existing optimization techniques forced to oversimplify the optimization problems. Until the end of the twentieth century, mainly deterministic optimization algorithms were used. Mostly they are just valid to a very limited extent since their application require in-depth knowledge of programming and optimization and they neglect important aspects (see Fig. 17a). However, this situation changed with the integration of stochastic optimization algorithms in product development aiming to solve the engineering problems in a more realistic way. Due to their strengths, first successful applications of stochastic optimization techniques in the context of tolerance-cost optimization were not long in coming after their initial introductions, e.g of SA in 1983 [316], GA in 1989 [317] or PSO in 1995 [318] (see Fig 17a). Since then, these methods have become more and more popular and are frequently used to solve the different multiconstrained, single- and multiobjective optimization problems with continuous but also discrete variables (see Fig. 7). The rapid development of computer technology has made a significant contribution to this change [12, 233, 319]. While the limited computer performance severely restricted the applicability of optimization algorithms in the beginning, today's computer technology enables the solving of complex, computing-intensive tolerance-cost optimization problems [53].

Concurrent tolerance design Fostered by the increasing technical possibilities, the method itself has further been improved with respect to the cost and tolerance analysis model. The traditional separation of the individual divisions has changed to a concurrent perception of product development (see Section 2.1). Thus, the increasing merge of manufacturing and design is reflected by the rising concurrent allocation of design and manufacturing tolerances (see Fig. 8). Although the solely consideration of design tolerances still predominates the optimal tolerance allocation, an increasing link of both disciplines in tolerance-cost optimization can be recognized (see Fig. 17b).

Quality Loss Focusing on the tolerance-cost model, it can be seen that TAGUCHI's idea of quality was already recognized in the early $90 \mathrm{~s}$ and integrated into tolerancecost optimization (see Fig. 7). The loss of quality significantly shaped the subsequent research activities and is considered additionally to the manufacturing costs in context of robust tolerance design (see Fig. 17c).

Technical system and tolerance analysis model Although most problems in engineering are 3D problems, they are mostly reduced to $1 \mathrm{D}$ or $2 \mathrm{D}$. Thus, the geometrical KCs are mostly described by linear and simple nonlinear KCs to reduce the complexity of tolerance analysis and thus the computational effort (see Fig. 17d). In comparison with tolerance analysis, optimal tolerance allocation is mainly based on dimensional tolerances [39]. Geometrical tolerances are just rarely allocated and current standards are often neglected (see Fig. 17e). The strengths of statistical tolerancing have already been recognized at the beginnings and have mostly been applied over the years (see Fig. 17f). Worst-case approaches are usually only used if other aspects are mainly in focus and the aspects of tolerance analysis are moved to the background. However, simplified statistical approaches, especially the root sum square approach, are preferred to sampling techniques due to shorter computing times (see Fig. 8).

\subsection{Current drawbacks and future research needs}

Since its first ideas in the middle of the twentieth century, tolerance-cost optimization tremendously evolved to a powerful instrument for optimal tolerance allocation. Nevertheless, several problems are still unsolved and currently an obstacle for its consistent industrial implementation.

Sophisticated tolerance analysis models While industry struggles with high system complexity mostly driven by increasing digitalization and mechatronization, most studies focus on relatively simple applications under more but rather less realistic simplifications and assumptions (see Section 4.1). To ensure the applicability of tolerance-cost optimization to industrial problems, the tolerance analysis model must consequently be tailored to the present and future needs of industry. This will require a further expansion of the methods to consider the various effects on non-geometrical KCs with focus on (robust) tolerance design. Hence, the convenient assumption that problems can easily be reduced to $1 \mathrm{D}$ or at least $2 \mathrm{D}$, is often too optimistic and unrealistic. Rather, tolerance-cost optimization must be enhanced to efficiently consider 3D effects. Therefore, the obsolete idea of a tolerance specification only based on dimensional tolerances must continuously be discarded. New approaches and strategies are essential to properly consider GD\&Ts in alignment with current standards in tolerance-cost optimization. This consequently implies the development of mathematical models to efficiently and properly represent geometrical part deviations. However, especially when sampling techniques are used in combination with stochastic optimization algorithms, current approaches reach the limit of a reasonable computing time, especially for the optimization of time-variant and over- and under-constrained systems. The development of efficient optimization algorithms and procedures will thus 
become even more important in future to cope with the compellingly increasing complexity of tolerance analysis models.

Availability of tolerance-cost data However, all these efforts to improve the tolerance analysis model are in vain if the tolerance-cost data and thus the objective function are too imprecise [88]. Since it beginnings, the lack of suitable and accurate tolerance-cost information has been criticized in literature over and over [9, 18, 81, 88, 97, 177, 178, 320]. However, little progress has been made over the years and reliable, up-to-date tolerance-cost data is still missing [178]. As a consequence, tolerance-cost optimization cannot thoroughly address new manufacturing technologies, e.g. additive manufacturing or the manufacturing of fibre-reinforced plastic parts, since reliable tolerance-cost data has not been published yet. While academic literature mostly deals with randomly chosen or obsolete tolerance-cost data, it is not really known whether and to what extent tolerance-cost data is available in industry and used for tolerance-cost optimization $[9,18]$. Despite the well-known benefits of tolerancecost optimization, the huge effort to gather, to process and to provide appropriate data in sufficient quantities often prevents industry from its application. Information from manufacturing and measurement must consequently flow back to tolerance design to provide up-to-date data taking advantage of the increasing digitalization of product development [321]. Therefore, suitable strategies and methods for the automatic acquisition and conversion of information from measurement and manufacturing into tolerance-cost models have to be developed. In addition, currently missing information from manufacturing, assembly and measurement must also be integrated in the total framework of tolerance-cost optimization. Even though design and manufacturing are more closely linked by concurrent tolerance design today (see Fig. 17b), a further shift from a mere product-related to a process-oriented tolerance allocation is necessary [18].

Applicability Last but not least, the initially discussed complexity of tolerance-cost optimization often dissuades from using it. Therefore, countermeasures, e.g. in the form of expert systems or the development of more easy-applicable optimization algorithms, are important and have to further be investigated to ensure and improve its usability of the steadily enhanced method. In addition, a comprehensible presentation of tolerance-cost optimization in literature is essential to make the method more accessible and transparent for practitioners and researchers.

\section{Conclusion}

Tolerance-cost optimization has been studied for over half a century. In comparison with tolerance analysis, it is more sophisticated and complex since it requires knowledge in optimization, tolerancing, manufacturing, cost modelling and programming. Although its strengths and benefits are well known in research and industry, its potential remains mostly unused since the method with its different, interrelated aspects is often not correctly and fully understood.

With the aim to overcome this drawback, this review article gave a holistic overview of tolerance-cost optimization. The first part of this article illustrated the fundamental idea of tolerance-cost optimization step-by-step and thus is particularly suitable for inexperienced readers. In the second part, a comprehensive mind map covering all relevant aspects of tolerance-cost optimization was presented and discussed in detail. A retrospect on the last fifty years of research studying 290 publications with focus on tolerancecost optimization illustrated its historical development and served as a basis to identify the current drawbacks and future research needs.

Acknowledgements The authors thank the German Research Foundation (DFG) for supporting the research project "Tolerance optimization of statically under- and over-constrained assemblies" under the grant number WA 2913/25-1.

Funding Information Open Access funding provided by Projekt DEAL.

Open Access This article is licensed under a Creative Commons Attribution 4.0 International License, which permits use, sharing, adaptation, distribution and reproduction in any medium or format, as long as you give appropriate credit to the original author(s) and the source, provide a link to the Creative Commons licence, and indicate if changes were made. The images or other third party material in this article are included in the article's Creative Commons licence, unless indicated otherwise in a credit line to the material. If material is not included in the article's Creative Commons licence and your intended use is not permitted by statutory regulation or exceeds the permitted use, you will need to obtain permission directly from the copyright holder. To view a copy of this licence, visit http:// creativecommonshorg/licenses/by/4.0/.

\section{Appendix}

\section{A Summary of literature references}

The references used to outline the development of tolerancecost optimization in Section 4.1 are chronologically summarized in Table 2 including a selection of representative keywords. They were mostly chosen following to Figs. 7 and 8 emphasizing their main focus. 
Table 2 List of references for the historical analysis in Section 4.1

\begin{tabular}{|c|c|c|c|c|}
\hline Year & Author & Title & Keywords & DOI/ISBN \\
\hline 1970 & G. Bennett & LEAST-COST TOLERANCES-I & $\begin{array}{l}\text { Lagrange multiplier } \\
\text { method; Deterministic } \\
\text { optimization algorithm; }\end{array}$ & $10.1080 / 00207547008929830$ \\
\hline 1970 & G. Bennett & LEAST-COST TOLERANCES-II & $\begin{array}{l}\text { Lagrange multiplier } \\
\text { method; Deterministic } \\
\text { optimization algorithm; }\end{array}$ & $10.1080 / 00207547008929838$ \\
\hline 1970 & J. Peters & $\begin{array}{l}\text { Tolerancing the Compo- } \\
\text { nents of an Assembly for } \\
\text { Minimum Cost }\end{array}$ & $\begin{array}{l}\text { Statistical tolerance } \\
\text { evaluation; Graphical } \\
\text { approach; }\end{array}$ & $10.1115 / 1.3427830$ \\
\hline 1972 & J. F. Pinel & $\begin{array}{l}\text { Tolerance Assignment in } \\
\text { Linear Networks Using } \\
\text { Nonlinear Programming }\end{array}$ & $\begin{array}{l}\text { Deterministic optimiza- } \\
\text { tion algorithm; Worst- } \\
\text { case tolerance evalua- } \\
\text { tion; Linear network; }\end{array}$ & 10.1109/ТСТ.1972.1083506 \\
\hline 1972 & F. H. Speckhart & $\begin{array}{l}\text { Calculation of Tolerance } \\
\text { Based on a Minimum } \\
\text { Cost Approach }\end{array}$ & $\begin{array}{l}\text { Lagrange multiplier } \\
\text { method; Deterministic } \\
\text { optimization algorithm; }\end{array}$ & $10.1115 / 1.3428175$ \\
\hline 1973 & M. F. Spotts & $\begin{array}{l}\text { Allocation of Tolerances } \\
\text { to Minimize Cost of } \\
\text { Assembly }\end{array}$ & $\begin{array}{l}\text { Lagrange multiplier } \\
\text { method; Deterministic } \\
\text { optimization algorithm; }\end{array}$ & $10.1115 / 1.3438222$ \\
\hline 1973 & A. R. Thorbjornsen & $\begin{array}{l}\text { Computer-Aided Tol- } \\
\text { erance Assignment for } \\
\text { Linear Circuits with Cor- } \\
\text { related Elements }\end{array}$ & $\begin{array}{l}\text { Deterministic optimiza- } \\
\text { tion algorithm; Correla- } \\
\text { tion; Monte Carlo sam- } \\
\text { pling; Electrical circuit } \\
\text { design; }\end{array}$ & 10.1109/ТCT.1973.1083737 \\
\hline 1974 & J. W. Bandler & $\begin{array}{l}\text { Optimization of design } \\
\text { tolerances using nonlin- } \\
\text { ear programming }\end{array}$ & $\begin{array}{l}\text { Deterministic optimiza- } \\
\text { tion algorithm; Worst- } \\
\text { case tolerance evalua- } \\
\text { tion; }\end{array}$ & 10.1007/BF00933176 \\
\hline 1975 & G. H. Sutherland & $\begin{array}{l}\text { Mechanism Design: } \\
\text { Accounting for Manu- } \\
\text { facturing Tolerances and } \\
\text { Costs in Function Gener- } \\
\text { ating Problems }\end{array}$ & $\begin{array}{l}\text { System in motion; Sta- } \\
\text { tistical tolerance evalua- } \\
\text { tion; Lagrange multiplier } \\
\text { method; }\end{array}$ & $10.1115 / 1.3438551$ \\
\hline 1975 & D. Wilde & $\begin{array}{l}\text { Minimum Exponen- } \\
\text { tial Cost Allocation of } \\
\text { Sure-Fit Tolerances }\end{array}$ & $\begin{array}{l}\text { Closed form solution; } \\
\text { Worst-case tolerance } \\
\text { evaluation; }\end{array}$ & $10.1115 / 1.3438796$ \\
\hline 1977 & P. F. Ostwald & $\begin{array}{l}\text { A Method for Optimal } \\
\text { Tolerance Selection }\end{array}$ & $\begin{array}{l}\text { Alternative process } \\
\text { selection; Discrete opti- } \\
\text { mization; }\end{array}$ & $10.1115 / 1.3439279$ \\
\hline 1979 & Ø. Bjørke & Computer-aided Tolerancing & $\begin{array}{l}\text { Deterministic opti- } \\
\text { mization algorithm; } \\
\text { Tolerance-cost function; } \\
\text { Interrelated KCs; }\end{array}$ & 8251902525 \\
\hline 1979 & S. S. Rao & $\begin{array}{l}\text { Game Theory Approach } \\
\text { in Multicriteria Opti- } \\
\text { mization of Function } \\
\text { Generating Mechanisms }\end{array}$ & $\begin{array}{l}\text { Multiobjective optimiza- } \\
\text { tion ; System in motion; } \\
\text { Game theory approach; }\end{array}$ & $10.1115 / 1.3454072$ \\
\hline 1979 & H. Schjaer-Jacobsen & $\begin{array}{l}\text { Algorithms for Worst- } \\
\text { Case Tolerance } \\
\text { Optimization }\end{array}$ & $\begin{array}{l}\text { Worst-case tolerance } \\
\text { evaluation; Antenna } \\
\text { system; }\end{array}$ & 10.1109/TCS.1979.1084700 \\
\hline 1980 & H. Schjaer-Jacobsen & $\begin{array}{l}\text { Worst-Case Tolerance } \\
\text { Optimization of Antenna } \\
\text { Systems }\end{array}$ & $\begin{array}{l}\text { Worst-case tolerance } \\
\text { evaluation; Antenna } \\
\text { system; }\end{array}$ & 10.1109/TAP.1980.1142296 \\
\hline 1981 & W. Michael & $\begin{array}{l}\text { The Optimization Prob- } \\
\text { lem With Optimal Tol- } \\
\text { erance Assignment and } \\
\text { Full Acceptance }\end{array}$ & $\begin{array}{l}\text { Deterministic optimiza- } \\
\text { tion algorithm; Worst- } \\
\text { case tolerance evalua- } \\
\text { tion; }\end{array}$ & $10.1115 / 1.3254996$ \\
\hline
\end{tabular}


Table 2 (continued)

\begin{tabular}{|c|c|c|c|c|}
\hline Year & Author & Title & Keywords & DOI/ISBN \\
\hline 1982 & W. Michael & $\begin{array}{l}\text { The Optimal Tolerance } \\
\text { Assignment With Less } \\
\text { Than Full Acceptance }\end{array}$ & $\begin{array}{l}\text { Deterministic optimiza- } \\
\text { tion algorithm; Scrap } \\
\text { rate; Statistical tolerance } \\
\text { evaluation; }\end{array}$ & $10.1115 / 1.3256448$ \\
\hline 1983 & V. Kumar & $\begin{array}{l}\text { Optimization of toler- } \\
\text { ance for minimum man- } \\
\text { ufacturing cost of satis- } \\
\text { factory journal bearings }\end{array}$ & $\begin{array}{l}\text { Deterministic optimiza- } \\
\text { tion algorithm; Lagrange } \\
\text { multiplier method; }\end{array}$ & 10.1016/0043-1648(83)90085-6 \\
\hline 1985 & D. B. Parkinson & $\begin{array}{l}\text { Assessment and opti- } \\
\text { mization of dimensional } \\
\text { tolerances }\end{array}$ & $\begin{array}{l}\text { Deterministic optimiza- } \\
\text { tion algorithm; Proba- } \\
\text { bilistic methods; }\end{array}$ & $10.1016 / 0010-4485(85) 90216-7$ \\
\hline 1985 & S. E. Y. Sayed & $\begin{array}{l}\text { An efficient technique } \\
\text { for minimum-cost toler- } \\
\text { ance assignment }\end{array}$ & $\begin{array}{l}\text { Deterministic optimiza- } \\
\text { tion algorithm; Worst-case } \\
\text { tolerance evaluation; Elec- } \\
\text { trical circuit design; }\end{array}$ & $10.1177 / 003754978504400404$ \\
\hline 1986 & R. J. Balling & $\begin{array}{l}\text { Consideration of Worst- } \\
\text { Case Manufacturing Tol- } \\
\text { erances in Design Opti- } \\
\text { mization }\end{array}$ & $\begin{array}{l}\text { Deterministic optimiza- } \\
\text { tion algorithm; Worst- } \\
\text { case tolerance evalua- } \\
\text { tion; }\end{array}$ & $10.1115 / 1.3258751$ \\
\hline 1987 & B. G. Loosli & $\begin{array}{l}\text { Manufacturing Toler- } \\
\text { ance Cost Minimization } \\
\text { Using Discrete Opti- } \\
\text { mization For Alternate } \\
\text { Process Selection }\end{array}$ & $\begin{array}{l}\text { Lagrange multiplier } \\
\text { method; Discrete opti- } \\
\text { mization; Alternative } \\
\text { process selection; }\end{array}$ & - \\
\hline 1988 & K. W. Chase & $\begin{array}{l}\text { Design Issues in } \\
\text { Mechanical Tolerance } \\
\text { Analysis }\end{array}$ & $\begin{array}{l}\text { Lagrange multiplier } \\
\text { method; Deterministic } \\
\text { optimization algorithm; } \\
\text { Alternative process } \\
\text { selection; }\end{array}$ & - \\
\hline 1988 & A. Ilumoka & $\begin{array}{l}\text { Parameter tolerance } \\
\text { design for electrical } \\
\text { circuits }\end{array}$ & $\begin{array}{l}\text { Parameter, tolerance } \\
\text { design; Electrical circuit } \\
\text { design; Monte Carlo } \\
\text { sampling; }\end{array}$ & $10.1002 /$ qre. 4680040203 \\
\hline 1988 & S. H. Kim & $\begin{array}{l}\text { A pseudo-boolean } \\
\text { approach to determining } \\
\text { least cost tolerances }\end{array}$ & $\begin{array}{l}\text { Deterministic optimiza- } \\
\text { tion algorithm; Statisti- } \\
\text { cal tolerance evaluation; }\end{array}$ & $10.1080 / 00207548808947848$ \\
\hline 1988 & J. H. Rhyu & $\begin{array}{l}\text { Optimal Stochastic } \\
\text { Design of Four-Bar } \\
\text { Mechanisms for Toler- } \\
\text { ance and Clearance }\end{array}$ & $\begin{array}{l}\text { Multiobjective optimiza- } \\
\text { tion; System in motion; } \\
\text { Deterministic optimiza- } \\
\text { tion algorithm; }\end{array}$ & $10.1115 / 1.3267455$ \\
\hline 1988 & Z. Wu & $\begin{array}{l}\text { Evaluation of Cost } \\
\text {-Tolerance Algorithms } \\
\text { for Design Tolerance } \\
\text { Analysis and Synthesis }\end{array}$ & $\begin{array}{l}\text { Deterministic optimiza- } \\
\text { tion algorithm; Lagrange } \\
\text { multiplier method; } \\
\text { Tolerance-cost function; }\end{array}$ & 8961611 \\
\hline 1989 & W. Lee & $\begin{array}{l}\text { Optimum Selection } \\
\text { of Discrete Tolerances }\end{array}$ & $\begin{array}{l}\text { Discrete optimization; } \\
\text { Hasofer Lind reliabil- } \\
\text { ity index; Deterministic } \\
\text { optimization algorithm; }\end{array}$ & $10.1115 / 1.3258990$ \\
\hline 1990 & C. Andersen & $\begin{array}{l}\text { General System for } \\
\text { Least Cost Toler-ance } \\
\text { Allocation in Mechani- } \\
\text { cal Assemblies }\end{array}$ & $\begin{array}{l}\text { Deterministic optimiza- } \\
\text { tion algorithm; Lagrange } \\
\text { multiplier method; Sta- } \\
\text { tistical tolerance evalua- } \\
\text { tion; }\end{array}$ & - \\
\hline 1990 & Z. Dong & $\begin{array}{l}\text { Automated Tolerance } \\
\text { Optimization Using } \\
\text { Feature-driven, Produc- } \\
\text { tion Operation-based } \\
\text { Cost Models }\end{array}$ & $\begin{array}{l}\text { Tolerance-cost model; } \\
\text { Automated cost model- } \\
\text { ing; Knowledge-based } \\
\text { engineering; }\end{array}$ & - \\
\hline
\end{tabular}


Table 2 (continued)

\begin{tabular}{|c|c|c|c|c|}
\hline Year & Author & Title & Keywords & DOI/ISBN \\
\hline 1990 & K. C. Kapur & $\begin{array}{l}\text { Methodology for toler- } \\
\text { ance design using quality } \\
\text { loss function }\end{array}$ & $\begin{array}{l}\text { Robust tolerance design; } \\
\text { Quality loss; ; }\end{array}$ & $10.1016 / 0360-8352(90) 90116-4$ \\
\hline 1990 & W. Lee & $\begin{array}{l}\text { Tolerances: Their Analy- } \\
\text { sis and Synthesis }\end{array}$ & $\begin{array}{l}\text { Deterministic optimiza- } \\
\text { tion algorithm; Reliabil- } \\
\text { ity index; Statistical tol- } \\
\text { erance evaluation; }\end{array}$ & $10.1115 / 1.2899553$ \\
\hline 1990 & M. M. Sfantsikopoulos & $\begin{array}{l}\text { A cost-tolerance analyt- } \\
\text { ical approach for design } \\
\text { and manufacturing }\end{array}$ & $\begin{array}{l}\text { Concurrent tolerance } \\
\text { design; Tolerance } \\
\text { transfer; }\end{array}$ & 10.1007/BF02601602 \\
\hline 1991 & J. Cagan & $\begin{array}{l}\text { Optimal design for toler- } \\
\text { ance and manufacturing } \\
\text { allocation }\end{array}$ & $\begin{array}{l}\text { Concurrent tolerance } \\
\text { design; Stochastic } \\
\text { optimization algorithm; }\end{array}$ & 10.1184/R1/6490064.v1 \\
\hline 1992 & H. Vasseur & $\begin{array}{l}\text { Optimal Tolerance Allo- } \\
\text { cation for Improved Pro- } \\
\text { ductivity }\end{array}$ & $\begin{array}{l}\text { Concurrent tolerance } \\
\text { design; Inspection costs; } \\
\text { Quality loss; Alternative } \\
\text { process selection; }\end{array}$ & $10.1016 / \mathrm{s} 1474-6670(17) 54066-5$ \\
\hline 1992 & C. Zhang & $\begin{array}{l}\text { Simultaneous Optimiza- } \\
\text { tion of Design and Man- } \\
\text { ufacturing - Tolerances } \\
\text { with Process (Machine) } \\
\text { Selection }\end{array}$ & $\begin{array}{l}\text { Stochastic optimization } \\
\text { algorithm; Concurrent } \\
\text { tolerance design; Alter- } \\
\text { native process selection; }\end{array}$ & $10.1016 / \mathrm{S} 0007-8506(07) 61270-0$ \\
\hline 1993 & R. J. Gerth & $\begin{array}{l}\text { A minimum cost toler- } \\
\text { ance allocation method } \\
\text { for rocket engines and } \\
\text { robust rocket engine } \\
\text { design }\end{array}$ & $\begin{array}{l}\text { Robust design; Taguchi } \\
\text { methods; ANOVA; Non- } \\
\text { geometrical KC; }\end{array}$ & - \\
\hline 1993 & J. Lee & $\begin{array}{l}\text { Optimal tolerance allot- } \\
\text { ment using a genetic } \\
\text { algorithm and truncated } \\
\text { Monte Carlo simulation }\end{array}$ & $\begin{array}{l}\text { Stochastic optimization } \\
\text { algorithm; Monte Carlo } \\
\text { sampling; }\end{array}$ & $10.1016 / 0010-4485(93) 90075-Y$ \\
\hline 1993 & W. J. Lee & $\begin{array}{l}\text { Tolerance synthesis for } \\
\text { nonlinear systems based } \\
\text { on nonlinear program- } \\
\text { ming }\end{array}$ & $\begin{array}{l}\text { Deterministic optimiza- } \\
\text { tion algorithm; Hasofer } \\
\text { Lind reliability index; } \\
\text { Yield; }\end{array}$ & $10.1080 / 07408179308964265$ \\
\hline 1993 & A. Parkinson & $\begin{array}{l}\text { A General Approach for } \\
\text { Robust Optimal Design }\end{array}$ & $\begin{array}{l}\text { Robust design; Statisti- } \\
\text { cal tolerance evaluation; } \\
\text { Non-geometrical KC; }\end{array}$ & $10.1115 / 1.2919328$ \\
\hline 1993 & R. Söderberg & $\begin{array}{l}\text { Tolerance allocation } \\
\text { considering customer } \\
\text { and manufacturer } \\
\text { objectives }\end{array}$ & $\begin{array}{l}\text { Robust tolerance design; } \\
\text { Quality loss; }\end{array}$ & 791811816 \\
\hline 1993 & C. Zhang & $\begin{array}{l}\text { Integrated tolerance opti- } \\
\text { misation with simulated } \\
\text { annealing }\end{array}$ & $\begin{array}{l}\text { Concurrent tolerance } \\
\text { design; Stochastic } \\
\text { optimization algorithm; }\end{array}$ & 10.1007/BF01749907 \\
\hline 1993 & C. Zhang & $\begin{array}{l}\text { Tolerance analysis and } \\
\text { synthesis for cam mech- } \\
\text { anisms }\end{array}$ & $\begin{array}{l}\text { System in motion; } \\
\text { GD\&T; Deterministic } \\
\text { optimization algorithm; }\end{array}$ & $10.1080 / 00207549308956785$ \\
\hline 1993 & C. Zhang & $\begin{array}{l}\text { The discrete tolerance } \\
\text { optimization problem }\end{array}$ & $\begin{array}{l}\text { Stochastic optimization } \\
\text { algorithm; Discrete opti- } \\
\text { mization; }\end{array}$ & - \\
\hline 1994 & C. Bloebaum & $\begin{array}{l}\text { Multidisciplinary design } \\
\text { with tolerance allocation } \\
\text { for maximum quality }\end{array}$ & $\begin{array}{l}\text { Multidisciplinary optimiza- } \\
\text { tion; Compliant system; } \\
\text { Non-geometrical KC; }\end{array}$ & $10.2514 / 6.1994-1417$ \\
\hline 1994 & Z. Dong & $\begin{array}{l}\text { New Production Cost- } \\
\text { Tolerance Models for } \\
\text { Tolerance Synthesis }\end{array}$ & $\begin{array}{l}\text { Manufacturing costs; } \\
\text { Hybrid tolerance-cost } \\
\text { function; Polyonomial } \\
\text { tolerance-cost function; }\end{array}$ & $10.1115 / 1.2901931$ \\
\hline
\end{tabular}


Table 2 (continued)

\begin{tabular}{|c|c|c|c|c|}
\hline Year & Author & Title & Keywords & DOI/ISBN \\
\hline 1994 & R. J. Gerth & $\begin{array}{l}\text { A spreadsheet approach } \\
\text { to minimum cost toler- } \\
\text { ancing for rocket engines }\end{array}$ & $\begin{array}{l}\text { Manufacturing costs; } \\
\text { Spreadsheet; } \\
\text { Non-geometrical KC; }\end{array}$ & $10.1016 / 0360-8352(94) 90356-5$ \\
\hline 1994 & A. Jeang & $\begin{array}{l}\text { Tolerance design: } \\
\text { Choosing optimal toler- } \\
\text { ance specifications in the } \\
\text { design of machined parts }\end{array}$ & $\begin{array}{l}\text { Quality loss; Machin- } \\
\text { ing costs; Part dimension } \\
\text { distributions; }\end{array}$ & 10.1002/qre.4680100107 \\
\hline 1994 & R. Söderberg & $\begin{array}{l}\text { Tolerance Allocation } \\
\text { in a CAD Environment } \\
\text { Considering Quality and } \\
\text { Manufacturing Cost }\end{array}$ & $\begin{array}{l}\text { Robust tolerance design; } \\
\text { Quality loss; CAD; }\end{array}$ & - \\
\hline 1994 & R. Söderberg & $\begin{array}{l}\text { Robust design by toler- } \\
\text { ance allocation consider- } \\
\text { ing quality and manufac- } \\
\text { turing cost }\end{array}$ & $\begin{array}{l}\text { Robust tolerance design; } \\
\text { Quality loss; }\end{array}$ & - \\
\hline 1994 & K. Yang & $\begin{array}{l}\text { Parameter and tolerance } \\
\text { design in the engineering } \\
\text { modelling stage }\end{array}$ & $\begin{array}{l}\text { Parameter, tolerance } \\
\text { design; Quality loss; } \\
\text { Lagrange multiplier } \\
\text { method; }\end{array}$ & $10.1080 / 00207549408957101$ \\
\hline 1995 & B. Cheng & $\begin{array}{l}\text { Optimization of mechan- } \\
\text { ical assembly tolerances } \\
\text { by incorporating } \\
\text { Taguchi's quality loss } \\
\text { function }\end{array}$ & $\begin{array}{l}\text { Robust tolerance design; } \\
\text { Quality loss; Sensitivity } \\
\text { analysis; }\end{array}$ & 10.1016/0278-6125(95)98879-B \\
\hline 1995 & A. Jeang & $\begin{array}{l}\text { Economic tolerance } \\
\text { design for quality }\end{array}$ & $\begin{array}{l}\text { Robust tolerance design; } \\
\text { Quality loss; }\end{array}$ & 10.1002/qre.4680110207 \\
\hline 1995 & P. Kopardekar & $\begin{array}{l}\text { Tolerance allocation } \\
\text { using neural networks }\end{array}$ & $\begin{array}{l}\text { Artificial Neural } \\
\text { Network; Statistical } \\
\text { tolerance evaluation; }\end{array}$ & 10.1007/BF01186878 \\
\hline 1995 & M. Y. Nagarwala & $\begin{array}{l}\text { A Slope-Based Method } \\
\text { for Least Cost Tolerance } \\
\text { Allocation }\end{array}$ & $\begin{array}{l}\text { Deterministic optimiza- } \\
\text { tion algorithm; Alterna- } \\
\text { tive process selection; } \\
\text { Minimum-cost curve; }\end{array}$ & $10.1177 / 1063293 \times 9500300407$ \\
\hline 1995 & J. R. Rajasekera & $\begin{array}{l}\text { A new approach to toler- } \\
\text { ance allocation in design } \\
\text { cost analysis }\end{array}$ & $\begin{array}{l}\text { Deterministic optimiza- } \\
\text { tion algorithm; Lagrange } \\
\text { multiplier method; }\end{array}$ & $10.1080 / 03052159508941194$ \\
\hline 1996 & M. Chen & $\begin{array}{l}\text { Optimising tolerance } \\
\text { allocation for mechan- } \\
\text { ical components corre- } \\
\text { lated by selective assem- } \\
\text { bly }\end{array}$ & $\begin{array}{l}\text { Correlated variables; } \\
\text { Selective assembly; } \\
\text { Lagrange multiplier } \\
\text { method; }\end{array}$ & 10.1007/BF01179810 \\
\hline 1996 & É. Dupinet & $\begin{array}{l}\text { Tolerance allocation } \\
\text { based on fuzzy logic and } \\
\text { simulated annealing }\end{array}$ & $\begin{array}{l}\text { Fuzzy theory; Stochastic } \\
\text { optimization algorithm; }\end{array}$ & 10.1007/BF00122838 \\
\hline 1996 & M. P. Iannuzzi & $\begin{array}{l}\text { Tolerance Optimization } \\
\text { Using Genetic Algo- } \\
\text { rithms: Benchmarking } \\
\text { with Manual Analysis }\end{array}$ & $\begin{array}{l}\text { Stochastic optimization } \\
\text { algorithm; CAT; Monte } \\
\text { Carlo sampling; GD\&T; }\end{array}$ & 10.1007/978-94-009-1529-9_15 \\
\hline 1996 & A. Jeang & $\begin{array}{l}\text { Optimal tolerance design } \\
\text { for product life cycle }\end{array}$ & $\begin{array}{l}\text { Quality loss; Scrap costs; } \\
\text { Rework costs; }\end{array}$ & $10.1080 / 00207549608905020$ \\
\hline 1996 & S. Kanai & $\begin{array}{l}\text { Optimal Tolerance } \\
\text { Synthesis by Genetic } \\
\text { Algorithm under } \\
\text { the Machining and } \\
\text { Assembling Constraints }\end{array}$ & $\begin{array}{l}\text { Stochastic optimization } \\
\text { algorithm; GD\&T; CAD; }\end{array}$ & 10.1007/978-94-009-1529-9_16 \\
\hline 1996 & A. Kusiak & $\begin{array}{l}\text { Robust Tolerance Design } \\
\text { for Quality }\end{array}$ & $\begin{array}{l}\text { Robust tolerance design; } \\
\text { DOE; Design for Quality; }\end{array}$ & $10.1115 / 1.2803639$ \\
\hline
\end{tabular}


Table 2 (continued)

\begin{tabular}{|c|c|c|c|c|}
\hline Year & Author & Title & Keywords & DOI/ISBN \\
\hline 1996 & V. J. Skowronski & $\begin{array}{l}\text { Estimating gradients for } \\
\text { statistical tolerance syn- } \\
\text { thesis }\end{array}$ & $\begin{array}{l}\text { Deterministic optimiza- } \\
\text { tion algorithm; Statisti- } \\
\text { cal tolerance evaluation; } \\
\text { Monte Carlo sampling; }\end{array}$ & $10.1016 / 0010-4485(96) 00032-2$ \\
\hline 1996 & G. Zhang & $\begin{array}{l}\text { Simultaneous toler- } \\
\text { ancing for design and } \\
\text { manufacturing }\end{array}$ & $\begin{array}{l}\text { Concurrent tolerance } \\
\text { design; Alternative pro- } \\
\text { cess selection; Tolerance } \\
\text { charting; }\end{array}$ & $10.1080 / 00207549608905095$ \\
\hline 1997 & M. D. Al-Ansary & $\begin{array}{l}\text { Concurrent optimization } \\
\text { of design and machin- } \\
\text { ing tolerances using } \\
\text { the genetic algorithms } \\
\text { method }\end{array}$ & $\begin{array}{l}\text { Concurrent tolerance } \\
\text { design; Alternative pro- } \\
\text { cess selection; Stochastic } \\
\text { optimization algorithm; }\end{array}$ & 10.1016/S0890-6955(97)00033-3 \\
\hline 1997 & F. Ciarallo & $\begin{array}{l}\text { Optimization of propa- } \\
\text { gation in interval con- } \\
\text { straint networks for tol- } \\
\text { erance design }\end{array}$ & $\begin{array}{l}\text { Interval constraint net- } \\
\text { work; }\end{array}$ & 10.1109/ICSMC.1997.638348 \\
\hline 1997 & J. J. Dong & $\begin{array}{l}\text { Tolerance Analysis And } \\
\text { Synthesis In Variational } \\
\text { Design }\end{array}$ & $\begin{array}{l}\text { Variational model; } \\
\text { GD\&T; }\end{array}$ & 471145947 \\
\hline 1997 & Z. Dong & $\begin{array}{l}\text { Tolerance synthesis by } \\
\text { manufacturing cost mod- } \\
\text { eling and design opti- } \\
\text { mization }\end{array}$ & $\begin{array}{l}\text { Concurrent tolerance } \\
\text { design; Non-geometrical } \\
\text { KC; Tolerance-cost } \\
\text { function; }\end{array}$ & 978-0471145943 \\
\hline 1997 & C. Feng & $\begin{array}{l}\text { Robust Tolerance Design } \\
\text { With the Integer Pro- } \\
\text { gramming Approach }\end{array}$ & $\begin{array}{l}\text { Robust tolerance design; } \\
\text { Quality loss; Discrete } \\
\text { optimization; Process } \\
\text { capability index; }\end{array}$ & $10.1115 / 1.2831193$ \\
\hline 1997 & A. Jeang & $\begin{array}{l}\text { An approach of toler- } \\
\text { ance design for qual- } \\
\text { ity improvement and cost } \\
\text { reduction }\end{array}$ & Quality loss; & $10.1080 / 002075497195272$ \\
\hline 1997 & S. S. Lin & $\begin{array}{l}\text { Optimal tolerance design } \\
\text { for integrated design, } \\
\text { manufacturing, and } \\
\text { inspection with genetic } \\
\text { algorithms }\end{array}$ & $\begin{array}{l}\text { Concurrent tolerance } \\
\text { design; Stochastic opti- } \\
\text { mization algorithm; } \\
\text { Alternative machine } \\
\text { selection; }\end{array}$ & $978-0471145943$ \\
\hline 1997 & C. Y. Lin & $\begin{array}{l}\text { Study of an assembly tol- } \\
\text { erance allocation model } \\
\text { based on Monte Carlo } \\
\text { simulation }\end{array}$ & $\begin{array}{l}\text { Monte Carlo sampling; } \\
\text { Sensitivity analysis; }\end{array}$ & 10.1016/S0924-0136(97)00034-4 \\
\hline 1997 & A. O. Nassef & $\begin{array}{l}\text { Allocation of Geometric } \\
\text { Tolerances: New Crite- } \\
\text { rion and Methodology }\end{array}$ & $\begin{array}{l}\text { GD\&T; Alternative pro- } \\
\text { cess selection; Stochastic } \\
\text { optimization algorithm; } \\
\text { Tolerance types; }\end{array}$ & $10.1016 / \mathrm{s} 0007-8506(07) 60785-9$ \\
\hline 1997 & B. K. A. Ngoi & $\begin{array}{l}\text { A tolerancing optimisa- } \\
\text { tion method for product } \\
\text { design }\end{array}$ & $\begin{array}{l}\text { Concurrent tolerance } \\
\text { design; Deterministic } \\
\text { optimization algorithm; }\end{array}$ & 10.1007/BF01179611 \\
\hline 1997 & U. Roy & $\begin{array}{l}\text { Optimal tolerance } \\
\text { re-allocation for the gen- } \\
\text { erative process sequence }\end{array}$ & $\begin{array}{l}\text { Process planning; } \\
\text { Lagrange multiplier } \\
\text { method; Deterministic } \\
\text { optimization algorithm; }\end{array}$ & $10.1080 / 07408179708966310$ \\
\hline 1997 & V. J. Skowronski & $\begin{array}{l}\text { Using Monte-Carlo vari- } \\
\text { ance reduction in statisti- } \\
\text { cal tolerance synthesis }\end{array}$ & $\begin{array}{l}\text { Monte Carlo sampling; } \\
\text { Resampling; }\end{array}$ & $10.1016 / \mathrm{S} 0010-4485(96) 00050-4$ \\
\hline 1997 & H. Vasseur & $\begin{array}{l}\text { Use of a quality loss } \\
\text { function to select statisti- } \\
\text { cal tolerances }\end{array}$ & $\begin{array}{l}\text { Quality loss; Alternative } \\
\text { process selection; Pro- } \\
\text { cess capability index; }\end{array}$ & $10.1115 / 1.2831121$ \\
\hline
\end{tabular}


Table 2 (continued)

\begin{tabular}{|c|c|c|c|c|}
\hline Year & Author & Title & Keywords & DOI/ISBN \\
\hline 1997 & C. C. Wei & $\begin{array}{l}\text { Allocating tolerances to } \\
\text { minimize cost of non- } \\
\text { conforming assembly }\end{array}$ & Quality loss; Scrap rate; & $10.1108 / 01445159710191589$ \\
\hline 1998 & A. Ashiagbor & $\begin{array}{l}\text { Tolerance control } \\
\text { and propagation for the } \\
\text { product assembly } \\
\text { modeller }\end{array}$ & $\begin{array}{l}\text { Monte Carlo sampling; } \\
\text { Stochastic optimization } \\
\text { algorithm; GD\&T; CAD; }\end{array}$ & $10.1080 / 002075498193949$ \\
\hline 1998 & F. P. Bernardo & $\begin{array}{l}\text { Robust optimization } \\
\text { framework for process } \\
\text { parameter and tolerance } \\
\text { design }\end{array}$ & $\begin{array}{l}\text { Parameter, tolerance } \\
\text { design; Chemical plant } \\
\text { design; Sampling; }\end{array}$ & 10.1002/aic.690440908 \\
\hline 1998 & J. H. Choi & $\begin{array}{l}\text { Tolerance Optimization } \\
\text { for Mechanisms with } \\
\text { Lubricated Joints }\end{array}$ & $\begin{array}{l}\text { System in motion; Deter } \\
\text { ministic optimization } \\
\text { algorithm; Statistical } \\
\text { tolerance evaluation; }\end{array}$ & 10.1023/A:1009785211763 \\
\hline 1998 & Z. Dong & $\begin{array}{l}\text { Integrated Concurrent } \\
\text { Design of Toler- } \\
\text { ance Using Empirical } \\
\text { Manufacturing Cost } \\
\text { Models }\end{array}$ & $\begin{array}{l}\text { Concurrent tolerance } \\
\text { design; Process selec- } \\
\text { tion; Non-geometrical } \\
\text { KC; }\end{array}$ & - \\
\hline 1998 & Z. Dong & $\begin{array}{l}\text { Automated Cost Mod- } \\
\text { eling for Tolerance } \\
\text { Synthesis Using Manu- } \\
\text { facturing Process Data, } \\
\text { Knowledge Reasoning } \\
\text { and Optimization }\end{array}$ & $\begin{array}{l}\text { Tolerance-cost model; } \\
\text { Automated cost model- } \\
\text { ing; Knowledge-based } \\
\text { engineering; }\end{array}$ & 10.1007/978-1-4615-5797-5_22 \\
\hline 1998 & R. J. Gerth & $\begin{array}{l}\text { Towards A Designed } \\
\text { Experiments Approach } \\
\text { to Tolerance Design }\end{array}$ & $\begin{array}{l}\text { DOE; ANOVA; Taguchi } \\
\text { methods; }\end{array}$ & 10.1007/978-1-4615-5797-5_26 \\
\hline 1998 & C. C. $\mathrm{Li}$ & $\begin{array}{l}\text { Robust tolerance alloca- } \\
\text { tion using stochastic pro- } \\
\text { gramming }\end{array}$ & $\begin{array}{l}\text { Monte Carlo sampling; } \\
\text { Robust tolerance design; } \\
\text { Deterministic optimiza- } \\
\text { tion algorithm; }\end{array}$ & $10.1080 / 03052159808941250$ \\
\hline 1998 & C. C. Wu & $\begin{array}{l}\text { Tolerance design } \\
\text { for products with asym- } \\
\text { metric quality losses }\end{array}$ & $\begin{array}{l}\text { Robust tolerance design; } \\
\text { Quality loss; }\end{array}$ & $10.1080 / 002075498192670$ \\
\hline 1998 & C. C. Wu & $\begin{array}{l}\text { Component tolerance } \\
\text { design for mini- } \\
\text { mum quality loss and } \\
\text { manufacturing cost }\end{array}$ & $\begin{array}{l}\text { Robust tolerance design; } \\
\text { Quality loss; Determin- } \\
\text { istic optimization algo- } \\
\text { rithm; }\end{array}$ & $10.1016 / \mathrm{s} 0166-3615(97) 00087-0$ \\
\hline 1999 & K. W. Chase & $\begin{array}{l}\text { Minimum-Cost } \\
\text { Tolerance Allocation }\end{array}$ & $\begin{array}{l}\text { Lagrange multiplier } \\
\text { method; Deterministic } \\
\text { optimization algorithm; } \\
\text { Alternative process } \\
\text { selection; Tolerance-cost } \\
\text { data; }\end{array}$ & - \\
\hline 1999 & K. W. Chase & $\begin{array}{l}\text { Tolerance allocation } \\
\text { methods for designers }\end{array}$ & $\begin{array}{l}\text { Lagrange multiplier } \\
\text { method; Deterministic } \\
\text { optimization algorithm; } \\
\text { Alternative process } \\
\text { selection; Tolerance-cost } \\
\text { data; }\end{array}$ & - \\
\hline 1999 & R. J. Gerth & $\begin{array}{l}\text { Cost Tolerance Sensitiv- } \\
\text { ity Analysis for Concur- } \\
\text { rent Engineering Design }\end{array}$ & $\begin{array}{l}\text { Sensitivity analysis; } \\
\text { Tolerance-cost function; } \\
\text { GD\&T; }\end{array}$ & 10.1007/978-94-017-1705-2_32 \\
\hline
\end{tabular}


Table 2 (continued)

\begin{tabular}{|c|c|c|c|c|}
\hline Year & Author & Title & Keywords & DOI/ISBN \\
\hline 1999 & A. Jeang & $\begin{array}{l}\text { Optimal tolerance design } \\
\text { by response surface } \\
\text { methodology }\end{array}$ & $\begin{array}{l}\text { Surrogate model; } \\
\text { GD\&T; CAT; }\end{array}$ & $10.1080 / 002075499190284$ \\
\hline 1999 & A. Jeang & $\begin{array}{l}\text { Robust tolerance design } \\
\text { by computer experiment }\end{array}$ & $\begin{array}{l}\text { Robust tolerance design; } \\
\text { Surrogate model; } \\
\text { GD\&T; CAT; }\end{array}$ & $10.1080 / 002075499190851$ \\
\hline 1999 & A. Jeang & $\begin{array}{l}\text { Robust Tolerance Design } \\
\text { by Response Surface } \\
\text { Methodology }\end{array}$ & $\begin{array}{l}\text { Robust tolerance design; } \\
\text { Surrogate model; }\end{array}$ & $10.1007 / \mathrm{s} 001700050082$ \\
\hline 1999 & C. B. Kim & $\begin{array}{l}\text { Least cost tolerance } \\
\text { allocation and bicriteria } \\
\text { extension }\end{array}$ & $\begin{array}{l}\text { Heuristic optimization } \\
\text { algorithm; Alterna- } \\
\text { tive process selection; } \\
\text { Process sequence } \\
\text { selection; }\end{array}$ & $10.1080 / 095119299130155$ \\
\hline 1999 & W. Li & $\begin{array}{l}\text { AN INTEGRATED } \\
\text { METHOD OF PARAM- } \\
\text { ETER DESIGN AND } \\
\text { TOLERANCE DESIGN }\end{array}$ & $\begin{array}{l}\text { Parameter, tolerance } \\
\text { design; Non-geometrical } \\
\text { KC; Orthogonal array; }\end{array}$ & 10.1080/08982119908919258 \\
\hline 1999 & B. K. A. Ngoi & $\begin{array}{l}\text { Optimum tolerance allo- } \\
\text { cation in assembly }\end{array}$ & $\begin{array}{l}\text { Concurrent tolerance } \\
\text { design; Tolerance chart- } \\
\text { ing; }\end{array}$ & $10.1007 / \mathrm{s} 001700050116$ \\
\hline 1999 & C. Zhang & $\begin{array}{l}\text { Statistical tolerance syn- } \\
\text { thesis using distribution } \\
\text { function zones }\end{array}$ & $\begin{array}{l}\text { Distribution function } \\
\text { zones; }\end{array}$ & $10.1080 / 002075499189880$ \\
\hline 2000 & T. C. Chen & $\begin{array}{l}\text { A GA-based search } \\
\text { method for the tolerance } \\
\text { allocation problem }\end{array}$ & $\begin{array}{l}\text { Stochastic optimization } \\
\text { algorithm; Alternative } \\
\text { process selection; }\end{array}$ & $10.1016 / \mathrm{S} 0954-1810(00) 00006-6$ \\
\hline 2000 & B. R. Cho & $\begin{array}{l}\text { An integrated joint opti- } \\
\text { mization procedure for } \\
\text { robust and tolerance } \\
\text { design }\end{array}$ & $\begin{array}{l}\text { Robust tolerance design; } \\
\text { Surrogate model; Qual- } \\
\text { ity loss; }\end{array}$ & $10.1080 / 00207540050028115$ \\
\hline 2000 & H. R. Choi & $\begin{array}{l}\text { Optimal Tolerance Allo- } \\
\text { cation With Loss Func- } \\
\text { tions }\end{array}$ & $\begin{array}{l}\text { Quality loss; Determin- } \\
\text { istic optimization algo- } \\
\text { rithm; }\end{array}$ & $10.1115 / 1.1285918$ \\
\hline 2000 & C. Y. Chou & $\begin{array}{l}\text { Bivariate tolerance } \\
\text { design for lock wheels } \\
\text { by considering quality } \\
\text { loss }\end{array}$ & $\begin{array}{l}\text { Quality loss; Present } \\
\text { worth; Tolerance-cost } \\
\text { function; }\end{array}$ & $\begin{array}{l}" \\
\text { 10.1002/(SICI) 1099-1638 } \\
(200003 / 04) 16: 2 \\
<129:: \text { AID-QRE310>3.0.CO;2-J }\end{array}$ \\
\hline 2000 & C. Feng & $\begin{array}{l}\text { Robust Tolerance Syn- } \\
\text { thesis With the Design of } \\
\text { Experiments Approach }\end{array}$ & $\begin{array}{l}\text { Robust design; DOE; } \\
\text { Monte Carlo sampling; } \\
\text { Process capability index; }\end{array}$ & $10.1115 / 1.1285860$ \\
\hline 2000 & M. H. Gadallah & $\begin{array}{l}\text { Tolerance optimisa- } \\
\text { tion problem using a } \\
\text { near-to-global optimum }\end{array}$ & $\begin{array}{l}\text { Discrete optimization; } \\
\text { Orthogonal array; }\end{array}$ & 10.1504/ijedpo.2011.043567 \\
\hline 2000 & R. J. Gerth & $\begin{array}{l}\text { Minimum cost toleranc- } \\
\text { ing under uncertain cost } \\
\text { estimates }\end{array}$ & $\begin{array}{l}\text { DOE; Sensitivity analy- } \\
\text { sis; GD\&T; }\end{array}$ & 10.1023/A:1007667818580 \\
\hline 2000 & S. Ji & $\begin{array}{l}\text { Tolerance synthesis } \\
\text { using second-order } \\
\text { fuzzy comprehensive } \\
\text { evaluation and genetic } \\
\text { algorithm }\end{array}$ & $\begin{array}{l}\text { Fuzzy theory; Stochastic } \\
\text { optimization algorithm; }\end{array}$ & $10.1080 / 002075400422752$ \\
\hline 2000 & S. Ji & $\begin{array}{l}\text { Optimal tolerance allo- } \\
\text { cation based on fuzzy } \\
\text { comprehensive eval- } \\
\text { uation and genetic } \\
\text { algorithm }\end{array}$ & $\begin{array}{l}\text { Fuzzy theory; Stochastic } \\
\text { optimization algorithm; }\end{array}$ & $10.1007 / \mathrm{s} 001700070053$ \\
\hline
\end{tabular}


Table 2 (continued)

\begin{tabular}{|c|c|c|c|c|}
\hline Year & Author & Title & Keywords & DOI/ISBN \\
\hline 2000 & C. Kao & $\begin{array}{l}\text { Tolerance allocation via } \\
\text { simulation embedded } \\
\text { sequential quadratic } \\
\text { programming }\end{array}$ & $\begin{array}{l}\text { Monte Carlo sampling; } \\
\text { Deterministic optimiza- } \\
\text { tion algorithm; }\end{array}$ & $10.1080 / 00207540050205136$ \\
\hline 2000 & Y. J. Kim & $\begin{array}{l}\text { The Use of Response } \\
\text { Surface Designs in the } \\
\text { Selection of Optimum } \\
\text { Tolerance Allocation }\end{array}$ & $\begin{array}{l}\text { Surrogate model; DOE; } \\
\text { Box-Behnken design; }\end{array}$ & $10.1080 / 08982110108918622$ \\
\hline 2000 & C. L. Lee & $\begin{array}{l}\text { Tolerance design for } \\
\text { products with correlated } \\
\text { characteristics }\end{array}$ & $\begin{array}{l}\text { Quality loss; Interrelated } \\
\text { KCs; }\end{array}$ & $10.1016 / \mathrm{S} 0094-114 \mathrm{X}(00) 00022-7$ \\
\hline 2000 & C. C. Yang & $\begin{array}{l}\text { Interval constraint net- } \\
\text { works for tolerance anal- } \\
\text { ysis and synthesis }\end{array}$ & $\begin{array}{l}\text { Interval constraint net- } \\
\text { work; Worst-case toler- } \\
\text { ance evaluation; }\end{array}$ & $10.1017 / \mathrm{S} 0890060400144014$ \\
\hline 2001 & Z. Zhou & $\begin{array}{l}\text { Sequential Algorithm } \\
\text { Based on Number Theo- } \\
\text { retic Method for Statis- } \\
\text { tical Tolerance Analysis } \\
\text { and Synthesis }\end{array}$ & $\begin{array}{l}\text { Deterministic optimiza- } \\
\text { tion algorithm; Number } \\
\text { theoretic method; Monte } \\
\text { Carlo sampling; }\end{array}$ & $10.1115 / 1.1378795$ \\
\hline 2001 & M. C. Chen & $\begin{array}{l}\text { Tolerance synthesis by } \\
\text { neural learning and non- } \\
\text { linear programming }\end{array}$ & $\begin{array}{l}\text { Neural network; } \\
\text { Tolerance-cost function; } \\
\text { Deterministic optimiza- } \\
\text { tion algorithm; }\end{array}$ & $10.1016 / \mathrm{S} 0925-5273(00) 00044-\mathrm{X}$ \\
\hline 2001 & C. Chou & $\begin{array}{l}\text { Minimum-Loss Assem- } \\
\text { bly Tolerance Allocation } \\
\text { by Considering Product } \\
\text { Degradation and Time } \\
\text { Value of Money }\end{array}$ & $\begin{array}{l}\text { Quality loss; Tolerance- } \\
\text { cost function; Present } \\
\text { worth; }\end{array}$ & $10.1007 / \mathrm{s} 001700170202$ \\
\hline 2001 & C. X. Feng & $\begin{array}{l}\text { An optimization model } \\
\text { for concurrent selection } \\
\text { of tolerances and suppli- } \\
\text { ers }\end{array}$ & $\begin{array}{l}\text { External supply; Qual- } \\
\text { ity loss; Yield; Process } \\
\text { capability index; }\end{array}$ & $10.1016 / \mathrm{S} 0360-8352(00) 00047-4$ \\
\hline 2001 & A. Jeang & $\begin{array}{l}\text { Computer-aided tol- } \\
\text { erance synthesis with } \\
\text { statistical method and } \\
\text { optimization techniques }\end{array}$ & $\begin{array}{l}\text { Surrogate model; } \\
\text { GD\&T; CAT; }\end{array}$ & $10.1002 /$ qre .387 \\
\hline 2001 & T. R. Jefferson & $\begin{array}{l}\text { Quality Tolerancing and } \\
\text { Conjugate Duality }\end{array}$ & $\begin{array}{l}\text { Tolerance-cost functions; } \\
\text { Quality loss; }\end{array}$ & 10.1023/A:1013309716875 \\
\hline 2001 & R. N. Youngworth & $\begin{array}{l}\text { Elements of Cost-Based } \\
\text { Tolerancing }\end{array}$ & $\begin{array}{l}\text { Non-geometrical KC; } \\
\text { Monte Carlo sampling; } \\
\text { Optical system; }\end{array}$ & $10.1007 / \mathrm{s} 10043-001-0276-1$ \\
\hline 2002 & H. Y. Cheng & $\begin{array}{l}\text { Optimum Tolerances } \\
\text { Synthesis for Globoidal } \\
\text { Cam Mechanisms. }\end{array}$ & $\begin{array}{l}\text { System in motion; } \\
\text { Lagrange multiplier } \\
\text { method; Transmission } \\
\text { error; }\end{array}$ & 10.1299/jsmec. 45.519 \\
\hline 2002 & J. Deng & $\begin{array}{l}\text { The adaptive branch and } \\
\text { bound method of toler- } \\
\text { ance synthesis based on } \\
\text { the reliability index }\end{array}$ & $\begin{array}{l}\text { Stochastic optimization } \\
\text { algorithm; Reliability } \\
\text { index; Yield; }\end{array}$ & $10.1007 / \mathrm{s} 001700200142$ \\
\hline 2002 & B. Forouraghi & $\begin{array}{l}\text { Worst-case tolerance } \\
\text { design and quality assur- } \\
\text { ance via genetic algo- } \\
\text { rithms }\end{array}$ & $\begin{array}{l}\text { Stochastic optimization } \\
\text { algorithm; Worst-case } \\
\text { tolerance evaluation; }\end{array}$ & 10.1023/A:1014826824323 \\
\hline 2002 & A. Jeang & $\begin{array}{l}\text { A Statistical Dimension } \\
\text { and Tolerance Design for } \\
\text { Mechanical Assembly } \\
\text { Under Thermal Impact }\end{array}$ & $\begin{array}{l}\text { Robust tolerance design; } \\
\text { Parameter, tolerance } \\
\text { design; Surrogate model; } \\
\text { Thermal impact; }\end{array}$ & $10.1007 / \mathrm{s} 001700200214$ \\
\hline
\end{tabular}


Table 2 (continued)

\begin{tabular}{|c|c|c|c|c|}
\hline Year & Author & Title & Keywords & DOI/ISBN \\
\hline 2002 & A. Jeang & $\begin{array}{l}\text { Combined robust param- } \\
\text { eter and tolerance design } \\
\text { using orthogonal arrays }\end{array}$ & $\begin{array}{l}\text { Robust tolerance design; } \\
\text { Parameter, tolerance } \\
\text { design; Orthogonal } \\
\text { array; ANOVA; }\end{array}$ & $10.1007 / \mathrm{s} 001700200046$ \\
\hline 2002 & A. Jeang & $\begin{array}{l}\text { Concurrent optimisation } \\
\text { of parameter and toler- } \\
\text { ance design via com- } \\
\text { puter simulation and sta- } \\
\text { tistical method }\end{array}$ & $\begin{array}{l}\text { Robust tolerance design; } \\
\text { Parameter, tolerance } \\
\text { design; Surrogate model; }\end{array}$ & $10.1007 / \mathrm{s} 001700200045$ \\
\hline 2002 & J. P. Jordaan & $\begin{array}{l}\text { Optimization of design } \\
\text { tolerances through } \\
\text { response surface approx- } \\
\text { imations }\end{array}$ & $\begin{array}{l}\text { Yield; Monte Carlo sam- } \\
\text { pling; Surrogate model; }\end{array}$ & $10.1115 / 1.1381400$ \\
\hline 2002 & J. Teeravaraprug & $\begin{array}{l}\text { Deterministic Tolerance } \\
\text { Svnthesis of Nominal } \\
\text { Values a Consideration }\end{array}$ & $\begin{array}{l}\text { Deterministic optimiza- } \\
\text { tion algorithm; Param- } \\
\text { eter, tolerance design; } \\
\text { Quality loss; }\end{array}$ & - \\
\hline 2003 & A. Shan & $\begin{array}{l}\text { Genetic Algorithms in } \\
\text { Statistical Tolerancing }\end{array}$ & $\begin{array}{l}\text { Stochastic optimization } \\
\text { algorithm; Monte Carlo } \\
\text { sampling; }\end{array}$ & 10.1016/S0895-7177(03)90146-4 \\
\hline 2003 & B. W. Shiu & $\begin{array}{l}\text { Tolerance allocation for } \\
\text { compliant beam struc- } \\
\text { ture assemblies }\end{array}$ & $\begin{array}{l}\text { Compliant system; } \\
\text { Type-2-Assembly; } \\
\text { Process-oriented } \\
\text { tolerancing; }\end{array}$ & $10.1080 / 07408170304376$ \\
\hline 2003 & P. K. Singh & $\begin{array}{l}\text { Simultaneous optimal } \\
\text { selection of design and } \\
\text { manufacturing toler- } \\
\text { ances with different } \\
\text { stack-up conditions } \\
\text { using genetic algorithms }\end{array}$ & $\begin{array}{l}\text { Concurrent tolerance } \\
\text { design; Stochastic opti- } \\
\text { mization algorithm; }\end{array}$ & $10.1080 / 0020754031000087328$ \\
\hline 2003 & P. Di Stefano & $\begin{array}{l}\text { Tolerance analysis and } \\
\text { synthesis using the mean } \\
\text { shift model }\end{array}$ & $\begin{array}{l}\text { Statistical tolerance eval- } \\
\text { uation; Estimated mean } \\
\text { shift; }\end{array}$ & $10.1243 / 095440603762826477$ \\
\hline 2003 & C. C. Yang & $\begin{array}{l}\text { Optimum tolerance } \\
\text { design using constraint } \\
\text { networks and rela- } \\
\text { tive sensitivity ratio } \\
\text { algorithm }\end{array}$ & $\begin{array}{l}\text { Interval constraint net- } \\
\text { work; Worst-case toler- } \\
\text { ance evaluation; }\end{array}$ & $10.1080 / 713827209$ \\
\hline 2003 & C. C. Yang & $\begin{array}{l}\text { Optimum tolerance } \\
\text { design for complex } \\
\text { assemblies using hierar- } \\
\text { chical interval constraint } \\
\text { networks }\end{array}$ & $\begin{array}{l}\text { Interval constraint net- } \\
\text { work; Relative sensitiv- } \\
\text { ity algorithm; }\end{array}$ & $10.1016 / \mathrm{S} 0360-8352(03) 00072-\mathrm{X}$ \\
\hline 2003 & B. Ye & $\begin{array}{l}\text { Simultaneous tolerance } \\
\text { synthesis for manufac- } \\
\text { turing and quality }\end{array}$ & $\begin{array}{l}\text { Tolerance design for } \\
\text { quality; Sensitivity anal- } \\
\text { ysis; }\end{array}$ & $10.1007 / \mathrm{s} 00163-003-0029-1$ \\
\hline 2004 & Z. Li & $\begin{array}{l}\text { Product Tolerance Allo- } \\
\text { cation in Compliant } \\
\text { Multistation Assembly } \\
\text { Through Variation Prop- } \\
\text { agation and Analytical } \\
\text { Target Cascading }\end{array}$ & $\begin{array}{l}\text { Type-2-assembly; Multi- } \\
\text { station manufacturing; } \\
\text { Process-oriented toler- } \\
\text { ancing; Analytical target } \\
\text { cascading; }\end{array}$ & 10.1115/imece2004-60521 \\
\hline 2004 & G. Prabhaharan & $\begin{array}{l}\text { Genetic-algorithm-based } \\
\text { optimal tolerance allo- } \\
\text { cation using a least-cost }\end{array}$ & $\begin{array}{l}\text { Stochastic optimization } \\
\text { algorithm; Monte carlo } \\
\text { sampling; }\end{array}$ & $10.1007 / \mathrm{s} 00170-003-1606-1$ \\
\hline
\end{tabular}


Table 2 (continued)

\begin{tabular}{|c|c|c|c|c|}
\hline Year & Author & Title & Keywords & DOI/ISBN \\
\hline 2004 & N. Robles & $\begin{array}{l}\text { Optimal tolerance } \\
\text { allocation and process- } \\
\text { sequence selection } \\
\text { incorporating manufac- } \\
\text { turing capacities and } \\
\text { quality issues }\end{array}$ & $\begin{array}{l}\text { Quality loss; Process } \\
\text { capability index; Process } \\
\text { sequence selection; }\end{array}$ & $10.1016 / \mathrm{S} 0278-6125(05) 00002-6$ \\
\hline 2004 & P. K. Singh & $\begin{array}{l}\text { A genetic algorithm } \\
\text { based solution to opti- } \\
\text { mum tolerance synthe- } \\
\text { sis of mechanical assem- } \\
\text { blies with alternate } \\
\text { manufacturing pro- } \\
\text { cesses - Benchmark- } \\
\text { ing with the exhaustive } \\
\text { search method using the } \\
\text { Lagrange multiplier }\end{array}$ & $\begin{array}{l}\text { Stochastic optimization } \\
\text { algorithm; Alterna- } \\
\text { tive process selection; } \\
\text { Lagrange multiplier } \\
\text { method; }\end{array}$ & $10.1177 / 095440540421800709$ \\
\hline 2004 & P. K. Singh & $\begin{array}{l}\text { A genetic algorithm- } \\
\text { based solution to optimal } \\
\text { tolerance synthesis of } \\
\text { mechanical assemblies } \\
\text { with alternative man- } \\
\text { ufacturing processes: } \\
\text { Focus on complex } \\
\text { tolerancing problems }\end{array}$ & $\begin{array}{l}\text { Stochastic optimization } \\
\text { algorithm; Alterna- } \\
\text { tive process selection; } \\
\text { Interrelated KCs; }\end{array}$ & $10.1080 / 00207540410001733931$ \\
\hline 2005 & Y. Ding & $\begin{array}{l}\text { Process-oriented toler- } \\
\text { ancing for multi-station } \\
\text { assembly systems }\end{array}$ & $\begin{array}{l}\text { Type-2-assembly; } \\
\text { Multi-station manufac- } \\
\text { turing; Process-oriented } \\
\text { tolerancing; }\end{array}$ & $10.1080 / 07408170490507774$ \\
\hline 2005 & A. N. Haq & $\begin{array}{l}\text { Tolerance design opti- } \\
\text { mization of machine } \\
\text { elements using genetic } \\
\text { algorithm }\end{array}$ & $\begin{array}{l}\text { Stochastic optimization } \\
\text { algorithm; }\end{array}$ & $10.1007 / \mathrm{s} 00170-003-1855-\mathrm{z}$ \\
\hline 2005 & J. Hu & $\begin{array}{l}\text { Concurrent design of a } \\
\text { geometric parameter and } \\
\text { tolerance for assembly } \\
\text { and cost }\end{array}$ & $\begin{array}{l}\text { Multiobjective optimiza- } \\
\text { tion; GD\&T; Parameter, } \\
\text { tolerance design; Varia- } \\
\text { tion constraints; }\end{array}$ & $10.1080 / 00207540412331282051$ \\
\hline 2005 & J. Hu & $\begin{array}{l}\text { Dimensional and geo- } \\
\text { metric tolerance design } \\
\text { based on constraints }\end{array}$ & $\begin{array}{l}\text { GD\&T; Parameter, tol- } \\
\text { erance design; Variation } \\
\text { constraints; }\end{array}$ & $10.1007 / \mathrm{s} 00170-004-2086-7$ \\
\hline 2005 & M. F. Huang & $\begin{array}{l}\text { Concurrent process tol- } \\
\text { erance design based on } \\
\text { minimum product manu- } \\
\text { facturing cost and qual- } \\
\text { ity loss }\end{array}$ & $\begin{array}{l}\text { Concurrent tolerance } \\
\text { design; Quality loss; }\end{array}$ & $10.1007 / \mathrm{s} 00170-003-1911-8$ \\
\hline 2005 & G. Prabhaharan & $\begin{array}{l}\text { Sensitivity-based con- } \\
\text { ceptual design and toler- } \\
\text { ance allocation using the } \\
\text { continuous ants colony } \\
\text { algorithm (CACO) }\end{array}$ & $\begin{array}{l}\text { Stochastic optimization } \\
\text { algorithm; Sensitivity } \\
\text { analysis; Parameter, } \\
\text { tolerance design; }\end{array}$ & $10.1007 / \mathrm{s} 00170-003-1846-0$ \\
\hline 2005 & N. Pramanik & $\begin{array}{l}\text { A generic deviation- } \\
\text { based approach for syn- } \\
\text { thesis of tolerances }\end{array}$ & $\begin{array}{l}\text { Torsor model; Determin- } \\
\text { istic optimization algo- } \\
\text { rithm; }\end{array}$ & 10.1109/TASE.2005.853584 \\
\hline 2005 & S. S. Rao & $\begin{array}{l}\text { Optimum tolerance allo- } \\
\text { cation in mechanical } \\
\text { assemblies using an }\end{array}$ & $\begin{array}{l}\text { Deterministic opti- } \\
\text { mization algorithm; } \\
\text { Tolerance-cost function; }\end{array}$ & $10.1080 / 0305215512331328240$ \\
\hline
\end{tabular}


Table 2 (continued)

\begin{tabular}{|c|c|c|c|c|}
\hline Year & Author & Title & Keywords & DOI/ISBN \\
\hline 2005 & P. K. Singh & $\begin{array}{l}\text { Advanced optimal } \\
\text { tolerance design of } \\
\text { mechanical assemblies } \\
\text { with interrelated dimen- } \\
\text { sion chains and process } \\
\text { precision limits }\end{array}$ & $\begin{array}{l}\text { Stochastic optimization } \\
\text { algorithm; Interrelated } \\
\text { KCs; Alternative process } \\
\text { selection; }\end{array}$ & 10.1016/j.compind.2004.06.008 \\
\hline 2005 & P. K. Singh & $\begin{array}{l}\text { Comparative study of } \\
\text { genetic algorithm and } \\
\text { simulated annealing for } \\
\text { optimal tolerance design } \\
\text { formulated with discrete } \\
\text { and continuous variables }\end{array}$ & $\begin{array}{l}\text { Stochastic optimization } \\
\text { algorithm; Concur- } \\
\text { rent tolerance design; } \\
\text { Discrete optimization; } \\
\text { Alternative machine } \\
\text { selection; }\end{array}$ & $10.1243 / 095440505 \times 32643$ \\
\hline 2005 & P. Wang & $\begin{array}{l}\text { An integrated approach } \\
\text { to tolerance synthesis, } \\
\text { process selection and } \\
\text { machining parameter } \\
\text { optimization problems }\end{array}$ & $\begin{array}{l}\text { Concurrent tolerance } \\
\text { design; Machinig param- } \\
\text { eter selection; Alterna- } \\
\text { tive process selection; }\end{array}$ & $10.1080 / 00207540500050063$ \\
\hline 2005 & L. Xu & $\begin{array}{l}\text { Tolerance synthesis by } \\
\text { a new method for system } \\
\text { reliability-based } \\
\text { optimization }\end{array}$ & $\begin{array}{l}\text { First-order reliability } \\
\text { method; Deterministic } \\
\text { optimization algorithm; }\end{array}$ & $10.1080 / 03052150500229467$ \\
\hline 2006 & Y. L. Cao & $\begin{array}{l}\text { A robust tolerance } \\
\text { design method based on } \\
\text { fuzzy quality loss }\end{array}$ & $\begin{array}{l}\text { Robust tolerance design; } \\
\text { Fuzzy theory; Quality } \\
\text { loss; }\end{array}$ & $10.1007 / \mathrm{s} 11465-005-0010-\mathrm{y}$ \\
\hline 2006 & T. C. Chen & $\begin{array}{l}\text { An Immune Algorithm } \\
\text { for Least Cost Advanced } \\
\text { Tolerance Design Prob- } \\
\text { lem }\end{array}$ & $\begin{array}{l}\text { Stochastic optimization } \\
\text { algorithm; }\end{array}$ & $\begin{array}{l}\text { 10.4028/www.scientific.net/ } \\
\text { MSF.505-507.511 }\end{array}$ \\
\hline 2006 & L. Gao & $\begin{array}{l}\text { Particle Swarm Optimi- } \\
\text { zation for Simultaneous } \\
\text { Optimization of } \\
\text { Design and Machining } \\
\text { Tolerances }\end{array}$ & $\begin{array}{l}\text { Stochastic optimization } \\
\text { algorithm; Concurrent } \\
\text { tolerance design; }\end{array}$ & $10.5772 / 5110$ \\
\hline 2006 & A. N. Haq & $\begin{array}{l}\text { Particle swarm optimiza- } \\
\text { tion (PSO) algorithm for } \\
\text { optimal machining allo- } \\
\text { cation of clutch assem- } \\
\text { bly }\end{array}$ & $\begin{array}{l}\text { Stochastic optimization } \\
\text { algorithm; }\end{array}$ & $10.1007 / \mathrm{s} 00170-004-2274-5$ \\
\hline 2006 & K. L. Hsieh & $\begin{array}{l}\text { The study of cost- } \\
\text { tolerance model by } \\
\text { incorporating process } \\
\text { capability index into } \\
\text { product lifecycle cost }\end{array}$ & $\begin{array}{l}\text { Process capability index; } \\
\text { Quality loss; }\end{array}$ & $10.1007 / \mathrm{s} 00170-004-2385-\mathrm{z}$ \\
\hline 2005 & M. F. Huang & $\begin{array}{l}\text { Concurrent process tol- } \\
\text { erance design based on } \\
\text { minimum product manu- } \\
\text { facturing cost and qual- } \\
\text { ity loss }\end{array}$ & $\begin{array}{l}\text { Concurrent tolerance } \\
\text { design; Quality loss; } \\
\text { Interrelated KCs; Pro- } \\
\text { cess planning; }\end{array}$ & $10.1007 / \mathrm{s} 00170-003-1911-8$ \\
\hline 2006 & A. G. Krishna & $\begin{array}{l}\text { Simultaneous optimal } \\
\text { selection of design and } \\
\text { manufacturing toler- } \\
\text { ances with different } \\
\text { stack-up conditions } \\
\text { using scatter search }\end{array}$ & $\begin{array}{l}\text { Concurrent tolerance } \\
\text { design; Stochastic opti- } \\
\text { mization algorithm; ; }\end{array}$ & $10.1007 / \mathrm{s} 00170-005-0059-0$ \\
\hline 2008 & N. Lyu & $\begin{array}{l}\text { Optimal Tolerance Allo- } \\
\text { cation of Automotive } \\
\text { Pneumatic Control } \\
\text { Valves Based on Product }\end{array}$ & $\begin{array}{l}\text { Multiobjective optimiza- } \\
\text { tion; Monte Carlo sam- } \\
\text { pling; Surrogate model; } \\
\text { Non-geometrical KC; }\end{array}$ & 10.1115/detc2006-99592 \\
\hline
\end{tabular}


Table 2 (continued)

\begin{tabular}{|c|c|c|c|c|}
\hline Year & Author & Title & Keywords & DOI/ISBN \\
\hline 2006 & G. J. Savage & $\begin{array}{l}\text { Optimal mean and tol- } \\
\text { erance allocation using } \\
\text { conformance-based } \\
\text { design }\end{array}$ & $\begin{array}{l}\text { Conformance probabil- } \\
\text { ity; Quality loss; Non- } \\
\text { geometrical KC; }\end{array}$ & 10.1002/qre. 721 \\
\hline 2006 & P. K. Singh & $\begin{array}{l}\text { Concurrent optimal } \\
\text { adjustment of nominal } \\
\text { dimensions and selection } \\
\text { of tolerances considering } \\
\text { alternative machines }\end{array}$ & $\begin{array}{l}\text { Stochastic optimization } \\
\text { algorithm; Concur- } \\
\text { rent tolerance design; } \\
\text { Nominal dimensions; } \\
\text { Alternative machine } \\
\text { selection; }\end{array}$ & 10.1016/j.cad.2006.05.006 \\
\hline 2007 & J. Bruyere & $\begin{array}{l}\text { Optimization of Gear } \\
\text { Tolerances by Statisti- } \\
\text { cal Analysis and Genetic } \\
\text { Algorithm }\end{array}$ & $\begin{array}{l}\text { Stochastic optimization } \\
\text { algorithm; Monte Carlo } \\
\text { sampling; Gear design; }\end{array}$ & 10.1007/978-1-4020-6761-7_27 \\
\hline 2007 & S. C. Dimitrellou & $\begin{array}{l}\text { A Systematic Approach } \\
\text { for Cost Optimal Toler- } \\
\text { ance Design }\end{array}$ & $\begin{array}{l}\text { Expert system; CAD; } \\
\text { Tolerance elements; }\end{array}$ & - \\
\hline 2007 & J. Hu & $\begin{array}{l}\text { Tolerance modelling and } \\
\text { robust design for concur- } \\
\text { rent engineering }\end{array}$ & $\begin{array}{l}\text { Concurrent tolerance } \\
\text { design; Mathemati- } \\
\text { cal model; GD\&T; } \\
\text { Stochastic optimization } \\
\text { algorithm; }\end{array}$ & 10.1243/0954406JMES438 \\
\hline 2007 & M. N. Islam & $\begin{array}{l}\text { A practical approach to } \\
\text { tolerance allocation }\end{array}$ & $\begin{array}{l}\text { Decision matrix; Process } \\
\text { capability; }\end{array}$ & - \\
\hline 2007 & J. Lööf & $\begin{array}{l}\text { An Efficient Solution to } \\
\text { the Discrete Least-Cost } \\
\text { Tolerance Allocation } \\
\text { Problem with General } \\
\text { Loss Functions }\end{array}$ & $\begin{array}{l}\text { Quality loss; Discrete } \\
\text { optimization; }\end{array}$ & 10.1007/1-4020-5438-6_13 \\
\hline 2007 & G. Prabhaharan & $\begin{array}{l}\text { Concurrent optimization } \\
\text { of assembly tolerances } \\
\text { for quality with posi- } \\
\text { tion control using scatter } \\
\text { search approach }\end{array}$ & $\begin{array}{lr}\text { Stochastic } & \text { optimization } \\
\text { algorithm; } & \text { Concurrent } \\
\text { tolerance design; GD\&T; }\end{array}$ & $10.1080 / 00207540600596866$ \\
\hline 2007 & M. Siva Kumar & $\begin{array}{l}\text { Construction of closed- } \\
\text { form equations and } \\
\text { graphical representation } \\
\text { for optimal tolerance } \\
\text { allocation }\end{array}$ & $\begin{array}{l}\text { Lagrange multiplier } \\
\text { method; Graphical repre- } \\
\text { sention; }\end{array}$ & $10.1080 / 00207540600547422$ \\
\hline 2007 & J. Teeravaraprug & $\begin{array}{l}\text { A Comparative Study of } \\
\text { Probabilistic and Worst- } \\
\text { case Tolerance Synthe- } \\
\text { sis. }\end{array}$ & $\begin{array}{l}\text { Statistical tolerance eval- } \\
\text { uation; Worst-case toler- } \\
\text { ance evaluation; }\end{array}$ & - \\
\hline 2007 & Y. Wang & $\begin{array}{l}\text { Study on the tolerance } \\
\text { allocation optimiza- } \\
\text { tion by fuzzy-set weight- } \\
\text { center evaluation method }\end{array}$ & $\begin{array}{l}\text { Fuzzy theory; Manufac- } \\
\text { turing conditions; }\end{array}$ & $10.1007 / \mathrm{s} 00170-006-0471-0$ \\
\hline 2007 & Y. Wang & $\begin{array}{l}\text { Objective function of } \\
\text { cost in optimal tolerance } \\
\text { allocation }\end{array}$ & $\begin{array}{l}\text { Fuzzy theory; Manufac- } \\
\text { turing conditions; }\end{array}$ & - \\
\hline 2007 & B. Yang & $\begin{array}{l}\text { Functional tolerance } \\
\text { theory in incremental } \\
\text { growth design }\end{array}$ & $\begin{array}{l}\text { Functional tolerance the- } \\
\text { ory; Fuzzy theory; Qual- } \\
\text { ity loss; }\end{array}$ & $10.1007 / \mathrm{s} 11465-007-0059-\mathrm{x}$ \\
\hline 2007 & H. Ying & $\begin{array}{l}\text { The genetic polygon } \\
\text { algorithm and its appli- } \\
\text { cation in concurrent }\end{array}$ & $\begin{array}{l}\text { Stochastic optimization } \\
\text { algorithm; Concurrent } \\
\text { tolerance design; }\end{array}$ & 10.1049/cp:20060821 \\
\hline
\end{tabular}
design

Conformance probability; Quality loss; Non-

Stochastic optimization algorithm; Concur-

ve machine

Stochastic optimization algorithm; Monte Carlo

Expert system; CAD;

Concurrent tolerance

design; Mathemati-

model; GD\&

algorithm;

Quality loss; Discrete the Discrete Least-Cost

Tolerance Allocation Loss Functions search approach graphical representation for optimal tolerance llocation case Tolerance Synthe-

Study on the tolerance allocation optimization by fuzzy-set weightcost in optimal tolerance allocation growth design algorithm and its applitolerance optimization algorithm; Concurrent tolerance design; GD\&T;

$$
\text { method; Graphical repre- }
$$

Statistical tolerance evaluation; Worst-case toler-

Fuzzy theory; Manufacturing conditions;

Fuzzy theory; Manufacturing conditions;

Functional tolerance theity loss; tolerance design; 
Table 2 (continued)

\begin{tabular}{|c|c|c|c|c|}
\hline Year & Author & Title & Keywords & DOI/ISBN \\
\hline 2008 & S. K. Cao & $\begin{array}{l}\text { Tolerance Optimal } \\
\text { Design System Devel- } \\
\text { opment and Application } \\
\text { Based on UG Quick } \\
\text { Stack Module }\end{array}$ & $\begin{array}{l}\text { Stochastic optimization } \\
\text { algorithm; CAD; }\end{array}$ & 10.4028/www.scientific.net/AMM.10-12.801 \\
\hline 2008 & H. Chun & $\begin{array}{l}\text { Multibody approach for } \\
\text { tolerance analysis and } \\
\text { optimization of mechan- } \\
\text { ical systems }\end{array}$ & $\begin{array}{l}\text { System in motion; Sen- } \\
\text { sitivity analysis; Multi- } \\
\text { body simulation; }\end{array}$ & $10.1007 / \mathrm{s} 12206-007-1024-7$ \\
\hline 2008 & J. Y. Dantan & $\begin{array}{l}\text { Vectorial tolerance allo- } \\
\text { cation of bevel gear by } \\
\text { discrete optimization }\end{array}$ & $\begin{array}{l}\text { Monte Carlo sampling; } \\
\text { Stochastic optimization } \\
\text { algorithm; System in } \\
\text { motion; Gear design; }\end{array}$ & 10.1016/j.mechmachtheory. 2007.11 .002 \\
\hline 2008 & A. Etienne & $\begin{array}{l}\text { Variation management } \\
\text { by functional tolerance } \\
\text { allocation and manufac- } \\
\text { turing process selection }\end{array}$ & $\begin{array}{l}\text { Activity-based tolerance } \\
\text { allocation; Alternative } \\
\text { process selection; }\end{array}$ & $10.1007 / \mathrm{s} 12008-008-0055-3$ \\
\hline 2008 & Z. Li & $\begin{array}{l}\text { Product and Process } \\
\text { Tolerance Allocation in } \\
\text { Multistation Compliant } \\
\text { Assembly Using Analyt- } \\
\text { ical Target Cascading }\end{array}$ & $\begin{array}{l}\text { Multi-station assembly; } \\
\text { Type-2-Assembly; Ana- } \\
\text { lytical target cascading; }\end{array}$ & $10.1115 / 1.2943296$ \\
\hline 2008 & H. P. Peng & $\begin{array}{l}\text { Concurrent optimal } \\
\text { allocation of design } \\
\text { and process tolerances } \\
\text { for mechanical assem- } \\
\text { blies with interrelated } \\
\text { dimension chains }\end{array}$ & $\begin{array}{l}\text { Concurrent tolerance } \\
\text { design; Interrelated KCs; } \\
\text { Deterministic optimiza- } \\
\text { tion algorithm; }\end{array}$ & $10.1080 / 00207540701427037$ \\
\hline 2008 & H. P. Peng & $\begin{array}{l}\text { Optimal tolerance design } \\
\text { for products with corre- } \\
\text { lated characteristics by } \\
\text { considering the present } \\
\text { worth of quality loss }\end{array}$ & $\begin{array}{l}\text { Interrelated KCs; Qual- } \\
\text { ity loss; Present worth; }\end{array}$ & $10.1007 / \mathrm{s} 00170-007-1205-7$ \\
\hline 2008 & A. K. Şehirlioğlu & $\begin{array}{l}\text { The use of mixture } \\
\text { experiments in tolerance } \\
\text { allocation problems }\end{array}$ & $\begin{array}{l}\text { DOE; Mixture-amount } \\
\text { experiment; }\end{array}$ & $10.1007 / \mathrm{s} 00170-006-0754-5$ \\
\hline 2008 & P. K. Singh & $\begin{array}{l}\text { Optimal tolerance design } \\
\text { of mechanical assem- } \\
\text { blies for economical } \\
\text { manufacturing in the } \\
\text { presence of alternative } \\
\text { machines - A genetic } \\
\text { algorithm-based hybrid } \\
\text { methodology }\end{array}$ & $\begin{array}{l}\text { Stochastic optimization } \\
\text { algorithm; Concur- } \\
\text { rent tolerance design; } \\
\text { Alternative machine } \\
\text { selection; }\end{array}$ & 10.1243/09544054JEM967 \\
\hline 2009 & R. A. Bowman & $\begin{array}{l}\text { Efficient Gradient-Based } \\
\text { Tolerance Optimization } \\
\text { Using Monte Carlo Sim- } \\
\text { ulation }\end{array}$ & $\begin{array}{l}\text { Deterministic optimiza- } \\
\text { tion algorithm; Monte } \\
\text { Carlo sampling; Sensi- } \\
\text { tivity; }\end{array}$ & $10.1115 / 1.3123328$ \\
\hline 2009 & Y. Cao & $\begin{array}{l}\text { A robust tolerance opti- } \\
\text { mization method based } \\
\text { on fuzzy quality loss }\end{array}$ & $\begin{array}{l}\text { Robust tolerance design; } \\
\text { Fuzzy theory; Quality } \\
\text { loss; }\end{array}$ & 10.1243/09544062JMES1451 \\
\hline 2009 & L. dos Santos Coelho & $\begin{array}{l}\text { Self-organizing migra- } \\
\text { tion algorithm applied to }\end{array}$ & $\begin{array}{l}\text { Stochastic optimization } \\
\text { algorithm; }\end{array}$ & 10.1016/j.matcom.2009.08.003 \\
\hline
\end{tabular}
machining allocation of clutch assembly 
Table 2 (continued)

\begin{tabular}{|c|c|c|c|c|}
\hline Year & Author & Title & Keywords & DOI/ISBN \\
\hline 2009 & B. Forouraghi & $\begin{array}{l}\text { Optimal tolerance allo- } \\
\text { cation using a multi- } \\
\text { objective particle swarm } \\
\text { optimizer }\end{array}$ & $\begin{array}{l}\text { Multiobjective opti- } \\
\text { mization; Stochastic } \\
\text { optimization algorithm; } \\
\text { Sensitivity analysis; }\end{array}$ & $10.1007 / \mathrm{s} 00170-008-1892-8$ \\
\hline 2009 & Y. M. Huang & $\begin{array}{l}\text { An optimal tolerance } \\
\text { allocation model for } \\
\text { assemblies with consid- } \\
\text { eration of manufactur- } \\
\text { ing cost, quality loss and } \\
\text { reliability index }\end{array}$ & $\begin{array}{l}\text { Quality loss; Reliability } \\
\text { index; }\end{array}$ & $10.1108 / 01445150910972903$ \\
\hline 2009 & J. Mao & $\begin{array}{l}\text { Manufacturing } \\
\text { environment-oriented } \\
\text { robust tolerance } \\
\text { optimization method }\end{array}$ & $\begin{array}{l}\text { Robust tolerance design; } \\
\text { Stochastic optimization } \\
\text { algorithm; Alterna- } \\
\text { tive process selection; } \\
\text { Process capability index; }\end{array}$ & $10.1007 / \mathrm{s} 00170-008-1460-2$ \\
\hline 2009 & P. Muthu & $\begin{array}{l}\text { Optimal tolerance design } \\
\text { of assembly for mini- } \\
\text { mum quality loss and } \\
\text { manufacturing cost using } \\
\text { metaheuristic algorithms }\end{array}$ & $\begin{array}{l}\text { Stochastic optimization } \\
\text { algorithm; Quality loss; }\end{array}$ & $10.1007 / \mathrm{s} 00170-009-1930-1$ \\
\hline 2009 & R. Sampath Kumar & $\begin{array}{l}\text { Simultaneous optimiza- } \\
\text { tion of design tolerance } \\
\text { and total cost for a piston } \\
\text { and cylinder assembly }\end{array}$ & $\begin{array}{l}\text { Concurrent tolerance } \\
\text { design; Stochastic opti- } \\
\text { mization algorithm; } \\
\text { Quality loss; }\end{array}$ & 10.1109/ARTCom.2009.179 \\
\hline 2009 & R. Sampath Kumar & $\begin{array}{l}\text { Optimization of design } \\
\text { tolerance and asymmet- } \\
\text { ric quality loss cost using } \\
\text { pattern search algorithm }\end{array}$ & $\begin{array}{l}\text { Stochastic optimization } \\
\text { algorithm; Asymmetric } \\
\text { quality loss; Concurrent } \\
\text { tolerance design; }\end{array}$ & - \\
\hline 2009 & M. Siva Kumar & $\begin{array}{l}\text { Optimum Tolerance } \\
\text { Synthesis for Complex } \\
\text { Assembly with Alterna- } \\
\text { tive Process Selection } \\
\text { Using Bottom Curve } \\
\text { Follower Approach }\end{array}$ & $\begin{array}{l}\text { Lagrange multiplier } \\
\text { method; Alternative pro- } \\
\text { cess selection; }\end{array}$ & - \\
\hline 2009 & M. Siva Kumar & $\begin{array}{l}\text { A new algorithm for } \\
\text { optimum tolerance } \\
\text { allocation of complex } \\
\text { assemblies with alterna- } \\
\text { tive processes selection }\end{array}$ & $\begin{array}{l}\text { Alternative process } \\
\text { selection; Stochastic } \\
\text { optimization algorithm; }\end{array}$ & $10.1007 / \mathrm{s} 00170-008-1389-5$ \\
\hline 2009 & M. Siva Kumar & $\begin{array}{l}\text { Optimum tolerance } \\
\text { synthesis for com- } \\
\text { plex assembly with alter- } \\
\text { native process selection } \\
\text { using Lagrange multi- } \\
\text { plier method }\end{array}$ & $\begin{array}{l}\text { Lagrange multiplier } \\
\text { method; Alternative pro- } \\
\text { cess selection; }\end{array}$ & $10.1007 / \mathrm{s} 00170-008-1866-\mathrm{x}$ \\
\hline 2009 & K. Sivakumar & $\begin{array}{l}\text { Optimal concurrent } \\
\text { dimensional and geo- } \\
\text { metrical tolerancing } \\
\text { based on evolutionary } \\
\text { algorithms }\end{array}$ & $\begin{array}{l}\text { Stochastic optimization } \\
\text { algorithm; Alterna- } \\
\text { tive process selection; } \\
\text { GD\&T; }\end{array}$ & 10.1109/NABIC.2009.5393725 \\
\hline 2009 & F. Wu & $\begin{array}{l}\text { Improved algorithm } \\
\text { for tolerance allocation } \\
\text { based on Monte Carlo } \\
\text { simulation and discrete } \\
\text { optimization }\end{array}$ & $\begin{array}{l}\text { Monte Carlo sam- } \\
\text { pling; Stochastic opti- } \\
\text { mization algorithm; } \\
\text { Over-constrained } \\
\text { system; }\end{array}$ & 10.1016/j.cie.2008.09.005 \\
\hline
\end{tabular}


Table 2 (continued)

\begin{tabular}{|c|c|c|c|c|}
\hline Year & Author & Title & Keywords & DOI/ISBN \\
\hline 2009 & K. T. Yu & $\begin{array}{l}\text { Combining tolerance } \\
\text { design and monitoring } \\
\text { process capability in a } \\
\text { design-manufacturing } \\
\text { integration procedure }\end{array}$ & $\begin{array}{l}\text { Process capability index; } \\
\text { Monitoring; }\end{array}$ & 10.1243/09544054JEM1497 \\
\hline 2009 & E. Zahara & $\begin{array}{l}\text { A hybridized approach } \\
\text { to optimal tolerance syn- } \\
\text { thesis of clutch assembly }\end{array}$ & $\begin{array}{l}\text { Stochastic optimization } \\
\text { algorithm; Hybrid opti- } \\
\text { mization algorithm; }\end{array}$ & $10.1007 / \mathrm{s} 00170-008-1418-4$ \\
\hline 2010 & A. Cui & $\begin{array}{l}\text { Tolerance Allocation } \\
\text { and Maintenance Opti- } \\
\text { mal Design for Fixture } \\
\text { in Multi-Station Panel } \\
\text { Assembly Process }\end{array}$ & $\begin{array}{l}\text { Multi-station assembly; } \\
\text { Type-2-assembly; Varia- } \\
\text { tion propagation; }\end{array}$ & 10.4028/www.scientific.net/amm.34-35.1039 \\
\hline 2010 & V. Janakiraman & $\begin{array}{l}\text { Concurrent optimization } \\
\text { of machining process } \\
\text { parameters and tolerance } \\
\text { allocation }\end{array}$ & $\begin{array}{l}\text { Machining parameters; } \\
\text { DOE; Stochastic opti- } \\
\text { mization algorithm; } \\
\text { Quality loss; }\end{array}$ & $10.1007 / \mathrm{s} 00170-010-2602-\mathrm{x}$ \\
\hline 2010 & G. Jayaprakash & $\begin{array}{l}\text { Parametric Tolerance Anal- } \\
\text { ysis of Mechanical Assem- } \\
\text { bly by Developing Direct } \\
\text { Constraint Model in CAD } \\
\text { and Cost Competent Toler- } \\
\text { ance Synthesis }\end{array}$ & $\begin{array}{l}\text { Surrogate model; } \\
\text { Stochastic optimization } \\
\text { algorithm; Compliant } \\
\text { system; CAD; GD\&T; }\end{array}$ & 10.4236/ica.2010.11001 \\
\hline 2010 & G. Jayaprakash & $\begin{array}{l}\text { Parametric Tolerance } \\
\text { Analysis of Mechanical } \\
\text { Assembly Using FEA } \\
\text { and Cost Competent Tol- } \\
\text { erance Synthesis Using } \\
\text { Neural Network }\end{array}$ & $\begin{array}{l}\text { Surrogate model; } \\
\text { Stochastic optimization } \\
\text { algorithm; Compliant } \\
\text { system; CAD; GD\&T; }\end{array}$ & 10.4236/jsea.2010.312134 \\
\hline 2010 & M. I. Mustajib & $\begin{array}{l}\text { An Integrated Model for } \\
\text { Process Selection and } \\
\text { Quality Improvement in } \\
\text { Multi-Stage Processes }\end{array}$ & $\begin{array}{l}\text { Alternative process } \\
\text { selection; Multi-stage } \\
\text { manufacturing; Quality } \\
\text { loss; }\end{array}$ & $10.1142 / \mathrm{s} 0219686710001788$ \\
\hline 2010 & B. K. Rout & $\begin{array}{l}\text { Simultaneous selection } \\
\text { of optimal parameters } \\
\text { and tolerance of manip- } \\
\text { ulator using evolutionary } \\
\text { optimization technique }\end{array}$ & $\begin{array}{l}\text { Stochastic optimiza- } \\
\text { tion algorithm; Sys- } \\
\text { tem in motion; Process } \\
\text { parameters; Parameter, } \\
\text { tolerance design; }\end{array}$ & $10.1007 / \mathrm{s} 00158-009-0368-2$ \\
\hline 2010 & R. Sampath Kumar & $\begin{array}{l}\text { Calculation of Total } \\
\text { Cost, Tolerance Based } \\
\text { on Taguchi's, Asymmet- } \\
\text { ric Quality Loss Func- } \\
\text { tion Approach }\end{array}$ & $\begin{array}{l}\text { Stochastic optimization } \\
\text { algorithm; Concur- } \\
\text { rent tolerance design; } \\
\text { Asymmetric quality loss; }\end{array}$ & 10.3844/ajeassp.2009.628.634 \\
\hline 2010 & R. Sampath Kumar & $\begin{array}{l}\text { Integrated optimization } \\
\text { of machining tolerance } \\
\text { and Asymmetric quality } \\
\text { loss cost for Rotor key } \\
\text { base assembly }\end{array}$ & $\begin{array}{l}\text { Stochastic optimization } \\
\text { algorithm; Concur- } \\
\text { rent tolerance design; } \\
\text { Asymmetric quality loss; }\end{array}$ & 413264300 \\
\hline 2010 & R. Sampath Kumar & $\begin{array}{l}\text { Integrated total cost and } \\
\text { tolerance optimization } \\
\text { with genetic algorithm }\end{array}$ & $\begin{array}{l}\text { Stochastic optimization } \\
\text { algorithm; Concur- } \\
\text { rent tolerance design; } \\
\text { Asymmetric quality loss; }\end{array}$ & $10.1080 / 18756891.2010 .9727703$ \\
\hline 2010 & K. Sivakumar & $\begin{array}{l}\text { Evolutionary sensitivity- } \\
\text { based conceptual design } \\
\text { and tolerance allocation } \\
\text { for mechanical assem- } \\
\text { blies }\end{array}$ & $\begin{array}{l}\text { Multiobjective opti- } \\
\text { mization; Stochastic } \\
\text { optimization algorithm; } \\
\text { Alternative process } \\
\text { selection; Parameter, tol- } \\
\text { erance design; }\end{array}$ & $10.1007 / \mathrm{s} 00170-009-2256-8$ \\
\hline
\end{tabular}


Table 2 (continued)

\begin{tabular}{|c|c|c|c|c|}
\hline Year & Author & Title & Keywords & DOI/ISBN \\
\hline 2010 & Z. Zhijie & $\begin{array}{l}\text { Optimal assembly tol- } \\
\text { erance design based } \\
\text { on fuzzy information } \\
\text { entropy and seeker opti- } \\
\text { mization algorithm }\end{array}$ & $\begin{array}{l}\text { Stochastic optimization } \\
\text { algorithm; Fuzzy theory; } \\
\text { Quality loss; }\end{array}$ & 10.1109/ICACTE.2010.5579339 \\
\hline 2011 & G. Campatelli & $\begin{array}{l}\text { Tolerance Synthesis } \\
\text { Using Axiomatic Design }\end{array}$ & $\begin{array}{l}\text { Axiomatic Design; Sta- } \\
\text { tistical tolerance evalua- } \\
\text { tion; }\end{array}$ & - \\
\hline 2011 & K. M. Cheng & $\begin{array}{l}\text { Optimal Statistical Tol- } \\
\text { erance Allocation of } \\
\text { Assemblies for Min- } \\
\text { imum Manufacturing } \\
\text { Cost }\end{array}$ & $\begin{array}{l}\text { Lagrange multiplier } \\
\text { method; Statistical toler- } \\
\text { ance evaluation; }\end{array}$ & 10.4028/www.scientific.net/.52-54.1818 \\
\hline 2011 & K. M. Cheng & $\begin{array}{l}\text { A Closed-Form } \\
\text { Approach for Optimum } \\
\text { Tolerance Allocation of } \\
\text { Assemblies with General } \\
\text { Tolerance-Cost Function }\end{array}$ & $\begin{array}{l}\text { Lagrange multiplier } \\
\text { method; Statistical toler- } \\
\text { ance evaluation; }\end{array}$ & 10.4028/www.scientific.net/amr.201-203.1272 \\
\hline 2011 & G. Jayaprakash & $\begin{array}{l}\text { Integration of thermo } \\
\text { mechanical strains into } \\
\text { optimal tolerance design } \\
\text { of mechanical assembly } \\
\text { using NSGA II and FE } \\
\text { simulations }\end{array}$ & $\begin{array}{l}\text { Surrogate model; } \\
\text { Stochastic optimization } \\
\text { algorithm; Compliant } \\
\text { system; Thermal impact; } \\
\text { CAD; }\end{array}$ & - \\
\hline 2011 & S. Jung & $\begin{array}{l}\text { Tolerance optimiza- } \\
\text { tion of a mobile phone } \\
\text { camera lens system }\end{array}$ & $\begin{array}{l}\text { Non-geometrical KC; } \\
\text { Latin hypercube sam- } \\
\text { pling; Optical } \\
\text { system; }\end{array}$ & 10.1364/ao.50.004688 \\
\hline 2011 & A. Kumar & $\begin{array}{l}\text { Tolerance allocation of } \\
\text { assemblies using fuzzy } \\
\text { comprehensive evalua- } \\
\text { tion and decision support } \\
\text { process }\end{array}$ & $\begin{array}{l}\text { Fuzzy theory; Decision } \\
\text { support process; }\end{array}$ & $10.1007 / \mathrm{s} 00170-010-3047-y$ \\
\hline 2011 & F. Z. Li & $\begin{array}{l}\text { A Robust Approach } \\
\text { for Concurrent Tol- } \\
\text { erances Allocation Using } \\
\text { Immune Genetic Algo- } \\
\text { rithm }\end{array}$ & $\begin{array}{l}\text { Stochastic optimization } \\
\text { algorithm; }\end{array}$ & 10.4028/www.scientific.net/ amr.308-310.776 \\
\hline 2011 & H. B. Qiu & $\begin{array}{l}\text { Tolerance Optimization } \\
\text { Design Based on Physi- } \\
\text { cal Programming Meth- } \\
\text { ods and PSO Algorithm }\end{array}$ & $\begin{array}{l}\text { Stochastic optimization } \\
\text { algorithm; Physical pro- } \\
\text { gramming; }\end{array}$ & 10.4028/www.scientific.net/ amr.346.584 \\
\hline 2011 & Y. S. Rao & $\begin{array}{l}\text { Simultaneous Tolerance } \\
\text { Synthesis for Manufac- } \\
\text { turing and Quality using } \\
\text { Evolutionary Algorithms }\end{array}$ & $\begin{array}{l}\text { Stochastic optimization } \\
\text { algorithm; Concurrent } \\
\text { tolerance design; }\end{array}$ & $10.4018 /$ jaec.2011040101 \\
\hline 2011 & A. Sanz Lobera & $\begin{array}{l}\text { Comparative Analysis of } \\
\text { Tolerances Allocation in } \\
\text { Mechanical Assemblies based } \\
\text { on Cost-tolerance Curves }\end{array}$ & $\begin{array}{l}\text { Lagrange multiplier } \\
\text { method; Deterministic } \\
\text { optimization algorithm; }\end{array}$ & $10.1063 / 1.4707566$ \\
\hline 2011 & K. Sivakumar & $\begin{array}{l}\text { Concurrent multi-objective } \\
\text { tolerance allocation of } \\
\text { mechanical assemblies consid- } \\
\text { ering alternative manufactur- } \\
\text { ing process selection }\end{array}$ & $\begin{array}{l}\text { Stochastic optimization } \\
\text { algorithm; Multiob- } \\
\text { jective optimization; } \\
\text { Alternative process } \\
\text { selection; }\end{array}$ & $10.1007 / \mathrm{s} 00170-010-2871-4$ \\
\hline
\end{tabular}


Table 2 (continued)

\begin{tabular}{|c|c|c|c|c|}
\hline Year & Author & Title & Keywords & DOI/ISBN \\
\hline 2011 & K. Sivakumar & $\begin{array}{l}\text { Evolutionary Advanced } \\
\text { Multi Objective Concur- } \\
\text { rent Tolerance Design of } \\
\text { Mechanical Assemblies }\end{array}$ & $\begin{array}{l}\text { Stochastic optimization } \\
\text { algorithm; Multiob- } \\
\text { jective optimization; } \\
\text { Concurrent tolerance } \\
\text { design; GD\&T; }\end{array}$ & - \\
\hline 2011 & K. Sivakumar & $\begin{array}{l}\text { Simultaneous optimal } \\
\text { selection of design and } \\
\text { manufacturing toler- } \\
\text { ances with alternative } \\
\text { manufacturing process } \\
\text { selection }\end{array}$ & $\begin{array}{l}\text { Concurrent tolerance } \\
\text { design; Stochastic } \\
\text { optimization algorithm; } \\
\text { Multiobjective optimiza- } \\
\text { tion; }\end{array}$ & 10.1016/j.cad.2010.10.001 \\
\hline 2011 & B. Zhong & $\begin{array}{l}\text { Fuzzy-Robust Design } \\
\text { Optimization of Dimen- } \\
\text { sion Tolerance Using the } \\
\text { Improved Genetic Algo- } \\
\text { rithm }\end{array}$ & $\begin{array}{l}\text { Fuzzy theory; Stochastic } \\
\text { optimization algorithm; } \\
\text { Robust design; }\end{array}$ & 10.4028/www.scientific.net/amm.55-57.1502 \\
\hline 2012 & L. Governi & $\begin{array}{l}\text { A genetic algorithms- } \\
\text { based procedure for } \\
\text { automatic tolerance allo- } \\
\text { cation integrated in a } \\
\text { commercial variation } \\
\text { analysis software }\end{array}$ & $\begin{array}{l}\text { Stochastic optimization } \\
\text { algorithm; Monte Carlo } \\
\text { sampling; CAT; }\end{array}$ & 10.3923/jai.2012.99.112 \\
\hline 2012 & G. Jayaprakash & $\begin{array}{l}\text { A numerical study on } \\
\text { effect of temperature } \\
\text { and inertia on tolerance } \\
\text { design of mechanical } \\
\text { assembly }\end{array}$ & $\begin{array}{l}\text { Compliant system; } \\
\text { Stochastic optimiza- } \\
\text { tion algorithm; External } \\
\text { influences; }\end{array}$ & $10.1108 / 02644401211257236$ \\
\hline 2012 & C. W. Lin & $\begin{array}{l}\text { Simultaneous optimal } \\
\text { design of parameters } \\
\text { and tolerance of bearing } \\
\text { locations for high-speed } \\
\text { machine tools using a } \\
\text { genetic algorithm and } \\
\text { Monte Carlo simulation } \\
\text { method }\end{array}$ & $\begin{array}{l}\text { Stochastic optimization } \\
\text { algorithm; Monte Carlo } \\
\text { sampling; Quality loss; }\end{array}$ & $10.1007 / \mathrm{s} 12541-012-0261-6$ \\
\hline 2011 & J. Lööf & $\begin{array}{l}\text { Discrete tolerance allo- } \\
\text { cation for product fami- } \\
\text { lies }\end{array}$ & $\begin{array}{l}\text { Discrete optimization; } \\
\text { Product families; CAT; }\end{array}$ & 10.1080/0305215X.2011.569545 \\
\hline 2012 & C. Lu & $\begin{array}{l}\text { Concurrent tolerance } \\
\text { design for manufacture } \\
\text { and assembly with a } \\
\text { game theoretic approach }\end{array}$ & $\begin{array}{l}\text { Concurrent tolerance } \\
\text { design; Stochastic opti- } \\
\text { mization algorithm; } \\
\text { GD\&T; Game theory; }\end{array}$ & $10.1007 / \mathrm{s} 00170-011-3783-7$ \\
\hline 2012 & M. I. Mustajib & $\begin{array}{l}\text { Concurrent Engineering } \\
\text { of Tolerance Synthesis } \\
\text { and Process Selection for } \\
\text { Products With Mul- } \\
\text { tiple Quality Character- } \\
\text { istcs Considering Pro- } \\
\text { cess Capability }\end{array}$ & $\begin{array}{l}\text { Concurrent tolerance } \\
\text { design; Quality loss; } \\
\text { Interrelated KCs; }\end{array}$ & 10.7454/mst.v16i1.1040 \\
\hline 2012 & H. Peng & $\begin{array}{l}\text { Concurrent tolerancing } \\
\text { for design and manu- } \\
\text { facturing based on the } \\
\text { present worth of quality } \\
\text { loss }\end{array}$ & $\begin{array}{l}\text { Concurrent tolerance } \\
\text { design; Quality loss; } \\
\text { Process capability index; }\end{array}$ & $10.1007 / \mathrm{s} 00170-011-3542-9$ \\
\hline 2012 & L. Shen & $\begin{array}{l}\text { Simultaneous optimiza- } \\
\text { tion of robust parame- } \\
\text { ter and tolerance design } \\
\text { based on generalized lin- } \\
\text { ear models }\end{array}$ & $\begin{array}{l}\text { Quality loss; Robust tol- } \\
\text { erance design; Stochastic } \\
\text { optimization algorithm; } \\
\text { Parameter, tolerance } \\
\text { design; }\end{array}$ & 10.1002/qre. 1462 \\
\hline
\end{tabular}


Table 2 (continued)

\begin{tabular}{|c|c|c|c|c|}
\hline Year & Author & Title & Keywords & DOI/ISBN \\
\hline 2012 & K. Sivakumar & $\begin{array}{l}\text { Evolutionary multi- } \\
\text { objective concurrent } \\
\text { maximisation of process } \\
\text { tolerances }\end{array}$ & $\begin{array}{l}\text { Multiobjective opti- } \\
\text { mization; Stochastic } \\
\text { optimization algorithm; } \\
\text { GD\&T; Concurrent tol- } \\
\text { erance design; }\end{array}$ & $10.1080 / 00207543.2010 .550637$ \\
\hline 2012 & Y. T. Ai & $\begin{array}{l}\text { Study on Technique of } \\
\text { Tolerance Optimal Allo- } \\
\text { cation Based on Adap- } \\
\text { tive Genetic Algorithm }\end{array}$ & $\begin{array}{l}\text { Stochastic optimization } \\
\text { algorithm; }\end{array}$ & 10.4028/www.scientific.net/amr.490-495.1436 \\
\hline 2015 & W. Chattinnawat & $\begin{array}{l}\text { Statistical tolerance } \\
\text { design to minimize } \\
\text { dual-responses of APFA } \\
\text { height deviations with } \\
\text { tolerance cost-quality } \\
\text { loss model }\end{array}$ & $\begin{array}{l}\text { Concurrent tolerance } \\
\text { design; Quality loss; } \\
\text { GD\&T; }\end{array}$ & 10.1108/IJQRM-06-2013-0096 \\
\hline 2013 & K. M. Cheng & $\begin{array}{l}\text { Optimal statistical toler- } \\
\text { ance allocation for recip- } \\
\text { rocal exponential cost- } \\
\text { tolerance function }\end{array}$ & $\begin{array}{l}\text { Lagrange multiplier } \\
\text { method; Statistical toler- } \\
\text { ance evaluation; }\end{array}$ & $10.1177 / 0954405412473720$ \\
\hline 2013 & K. Geetha & $\begin{array}{l}\text { Multi-objective opti- } \\
\text { mization for optimum } \\
\text { tolerance synthesis with } \\
\text { process and machine } \\
\text { selection using a genetic } \\
\text { algorithm }\end{array}$ & $\begin{array}{l}\text { Multiobjective opti- } \\
\text { mization; Stochastic } \\
\text { optimization algo- } \\
\text { rithm; Concurrent toler- } \\
\text { ance design; Alternative } \\
\text { process/ machine selec- } \\
\text { tion; }\end{array}$ & $10.1007 / \mathrm{s} 00170-012-4662-6$ \\
\hline 2013 & H. X. Guo & $\begin{array}{l}\text { Design Optimization } \\
\text { for the Robustness of } \\
\text { Dimensional Tolerance } \\
\text { by Using Evidence } \\
\text { Theory }\end{array}$ & $\begin{array}{l}\text { Evidence theory; Robust } \\
\text { tolerance design; }\end{array}$ & 10.4028/www.scientific.net/ amm.483.434 \\
\hline 2013 & T. C. Hung & $\begin{array}{l}\text { Multi-objective design } \\
\text { and tolerance allocation } \\
\text { for single- and multi- } \\
\text { level systems }\end{array}$ & $\begin{array}{l}\text { Multiobjective optimiza- } \\
\text { tion; Robust Tolerance } \\
\text { design; Analytical target } \\
\text { cascading; }\end{array}$ & $10.1007 / \mathrm{s} 10845-011-0608-3$ \\
\hline 2013 & S. G. Liu & $\begin{array}{l}\text { Analytical method for } \\
\text { optimal component tol- } \\
\text { erances based on manu- } \\
\text { facturing cost and qual- } \\
\text { ity loss }\end{array}$ & $\begin{array}{l}\text { Lagrange multiplier } \\
\text { method; Quality loss; }\end{array}$ & $10.1177 / 0954405413488769$ \\
\hline 2013 & S. G. Liu & $\begin{array}{l}\text { Closed-Form Optimal } \\
\text { Tolerance for Minimum } \\
\text { Manufacturing Cost and } \\
\text { Quality Loss Cost }\end{array}$ & $\begin{array}{l}\text { Lagrange multiplier } \\
\text { method; Quality loss; }\end{array}$ & 10.4028/www.scientific.net/amr.655-657.2084 \\
\hline 2013 & G. F. Piepel & $\begin{array}{l}\text { Optimum toler- } \\
\text { ance design using } \\
\text { component-amount and } \\
\text { mixture-amount experi- } \\
\text { ments }\end{array}$ & $\begin{array}{l}\text { DOE; Mixture- } \\
\text { amount experiment; } \\
\text { Component-amount } \\
\text { experiment; }\end{array}$ & $10.1007 / \mathrm{s} 00170-013-4844-\mathrm{x}$ \\
\hline 2013 & R. V. Rao & $\begin{array}{l}\text { Simultaneous Optimal } \\
\text { Selection of Design and } \\
\text { Manufacturing Toler- } \\
\text { ances with Different } \\
\text { Stack- up Conditions } \\
\text { using TLBO Algorithm }\end{array}$ & $\begin{array}{l}\text { Stochastic optimization } \\
\text { algorithm; Concurrent } \\
\text { tolerance design; }\end{array}$ & - \\
\hline
\end{tabular}


Table 2 (continued)

\begin{tabular}{|c|c|c|c|c|}
\hline Year & Author & Title & Keywords & DOI/ISBN \\
\hline 2013 & D. Shringi & $\begin{array}{l}\text { Simultaneous Optimiza- } \\
\text { tion of Tolerances for } \\
\text { Prismatic Part Assembly } \\
\text { in Different Stack up } \\
\text { Conditions }\end{array}$ & $\begin{array}{l}\text { Concurrent tolerance } \\
\text { design; Stochastic } \\
\text { optimization algorithm; }\end{array}$ & - \\
\hline 2013 & H. Towsyfyan & $\begin{array}{l}\text { The Comparison of } \\
\text { Imperialist Competitive } \\
\text { Algorithm Applied and } \\
\text { Genetic Algorithm for } \\
\text { Machining Allocation of } \\
\text { Clutch Assembly }\end{array}$ & $\begin{array}{l}\text { Stochastic optimization } \\
\text { algorithm; }\end{array}$ & - \\
\hline 2013 & M. S. J. Walter & $\begin{array}{l}\text { Statistical Tolerance- } \\
\text { Cost-Optimization of } \\
\text { Systems in Motion Tak- } \\
\text { ing into Account Differ- } \\
\text { ent Kinds of Deviations }\end{array}$ & $\begin{array}{l}\text { System in motion; } \\
\text { Monte Carlo sampling; } \\
\text { Time-variant system; }\end{array}$ & 10.1007/978-3-642-30817-8_69 \\
\hline 2014 & L. Andolfatto & $\begin{array}{l}\text { Quality- and cost-driven } \\
\text { assembly technique } \\
\text { selection and geometri- } \\
\text { cal tolerance allocation } \\
\text { for mechanical structure } \\
\text { assembly }\end{array}$ & $\begin{array}{l}\text { Multiobjective opti- } \\
\text { mization; Assembly pro- } \\
\text { cess planning; Type-2- } \\
\text { Assembly; }\end{array}$ & 10.1016/j.jmsy.2013.03.003 \\
\hline 2014 & S. Hoffenson & $\begin{array}{l}\text { Tolerance optimisation } \\
\text { considering economic } \\
\text { and environmental } \\
\text { sustainability }\end{array}$ & $\begin{array}{l}\text { Environmental, social } \\
\text { costs; Multiobjective } \\
\text { optimization; Variation } \\
\text { propagation; }\end{array}$ & $10.1080 / 09544828.2014 .994481$ \\
\hline 2014 & G. Jayaprakash & $\begin{array}{l}\text { Optimal tolerance design } \\
\text { for mechanical assem- } \\
\text { bly considering thermal } \\
\text { impact }\end{array}$ & $\begin{array}{l}\text { External influences; } \\
\text { GD\&T; Compliant sys- } \\
\text { tem; Surrogate model; } \\
\text { Thermal impact; }\end{array}$ & $10.1007 / \mathrm{s} 00170-014-5845-0$ \\
\hline 2014 & S. G. Liu & $\begin{array}{l}\text { Closed-form solutions } \\
\text { for multi-objective toler- } \\
\text { ance optimization }\end{array}$ & $\begin{array}{l}\text { Multiobjective optimiza- } \\
\text { tion; Lagrange multiplier } \\
\text { method; }\end{array}$ & $10.1007 / \mathrm{s} 00170-013-5437-4$ \\
\hline 2014 & M. Mazur & $\begin{array}{l}\text { A case study of effi- } \\
\text { cient tolerance synthe- } \\
\text { sis in product assemblies } \\
\text { under loading }\end{array}$ & $\begin{array}{l}\text { Monte Carlo sam- } \\
\text { pling; Polynomial chaos } \\
\text { expansion; External } \\
\text { influences; Process capa- } \\
\text { bility index; }\end{array}$ & $9,7819 \mathrm{E}+12$ \\
\hline 2014 & A. Otsuka & $\begin{array}{l}\text { Optimal allocation of } \\
\text { statistical tolerance } \\
\text { indices by genetic } \\
\text { algorithms }\end{array}$ & $\begin{array}{l}\text { GD\&T; Stochastic opti- } \\
\text { mization algorithm; Pro- } \\
\text { cess capability index; }\end{array}$ & $10.1007 / \mathrm{s} 10015-014-0157-\mathrm{x}$ \\
\hline 2014 & R. V. Rao & $\begin{array}{l}\text { Advanced optimal toler- } \\
\text { ance design of machine } \\
\text { elements using teaching- } \\
\text { learning-based optimiza- } \\
\text { tion algorithm }\end{array}$ & $\begin{array}{l}\text { Stochastic optimization } \\
\text { algorithm; Multiob- } \\
\text { jective optimization; } \\
\text { Concurrent tolerance } \\
\text { design; }\end{array}$ & $10.1080 / 21693277.2014 .892845$ \\
\hline 2014 & C. N. Rosyidi & $\begin{array}{l}\text { Make or Buy Analysis } \\
\text { Model Based on Toler- } \\
\text { ance Design to Minimize } \\
\text { Manufacturing Cost and } \\
\text { Quality Loss }\end{array}$ & $\begin{array}{l}\text { External supply; Quality } \\
\text { loss; Decision process; }\end{array}$ & 10.7454/mst.v18i2.2947 \\
\hline 2014 & A. Sahani & $\begin{array}{l}\text { Design Verification } \\
\text { through Tolerance Stack }\end{array}$ & $\begin{array}{l}\text { GD\&T; Statistical toler- } \\
\text { ance evaluation; }\end{array}$ & 10.1016/j.mspro.2014.07.036 \\
\hline
\end{tabular}
up Analysis of Mechanical Assembly and Least Cost Tolerance Allocation 
Table 2 (continued)

\begin{tabular}{|c|c|c|c|c|}
\hline Year & Author & Title & Keywords & DOI/ISBN \\
\hline 2014 & A. Saravanan & $\begin{array}{l}\text { Optimal geometric } \\
\text { tolerance design frame- } \\
\text { work for rigid parts } \\
\text { with assembly function } \\
\text { requirements using evo- } \\
\text { lutionary algorithms }\end{array}$ & $\begin{array}{l}\text { GD\&T; Stochastic } \\
\text { optimization algorithm; } \\
\text { Multiobjective optimiza- } \\
\text { tion; }\end{array}$ & $10.1007 / \mathrm{s} 00170-014-5908-2$ \\
\hline 2014 & Y. M. Zhao & $\begin{array}{l}\text { Optimization design } \\
\text { method of product gen- } \\
\text { eral tolerance system }\end{array}$ & $\begin{array}{l}\text { Non-geometrical KC; } \\
\text { Surrogate model; } \\
\text { GD\&T; }\end{array}$ & $10.1007 / \mathrm{s} 00170-013-5193-5$ \\
\hline 2015 & B. R. Barbero & $\begin{array}{l}\text { A tolerance analy- } \\
\text { sis and optimization } \\
\text { methodology. The com- } \\
\text { bined use of 3D CAT, } \\
\text { a dimensional hierar- } \\
\text { chization matrix and an } \\
\text { optimization algorithm }\end{array}$ & $\begin{array}{l}\text { GD\&T; Monte Carlo } \\
\text { sampling; CAT; Dimen- } \\
\text { sional hierarchization } \\
\text { matrix; }\end{array}$ & $10.1007 / \mathrm{s} 00170-015-7068-4$ \\
\hline 2015 & K. Geetha & $\begin{array}{l}\text { Concurrent toler- } \\
\text { ance allocation and } \\
\text { scheduling for complex } \\
\text { assemblies }\end{array}$ & $\begin{array}{l}\text { Concurrent tolerance } \\
\text { design; Stochastic opti- } \\
\text { mization algorithm; Pro- } \\
\text { cess scheduling; }\end{array}$ & 10.1016/j.rcim.2015.03.001 \\
\hline 2015 & Q. Jin & $\begin{array}{l}\text { Optimal tolerance design } \\
\text { for products with non- } \\
\text { normal distribution } \\
\text { based on asymmetric } \\
\text { quadratic quality loss }\end{array}$ & $\begin{array}{l}\text { Asymmetric quality loss; } \\
\text { Concurrent tolerance } \\
\text { design; }\end{array}$ & 10.1007/s00170-014-6681-y \\
\hline 2015 & L. Ramesh Kumar & Optimal Manufacturing & Worst-case tolerance & $.4028 /$ www.scientific.net/amm.766-767.1097 \\
\hline
\end{tabular}

evaluation; Alterna-

tive process selection;

Quality loss;

Compliant system; Polynomial chaos expansion; Monte Carlo sampling; External influences; Synthesis in Compliant Assemblies Subject to Loading

2015 M. S. J. Walter

$2015 \quad$ Y. Zong

2016 M. Han
Tolerance optimization design based on the manufacturing-costs of assembly quality

Integrated parameter and tolerance design with computer experiments

A Novel Approach to Simultaneous Robust Design of Product Parameters and Tolerances Using Quality Loss and Multivariate ANOVA Concepts
System in motion;

Time-variant system;

Monte Carlo sampling; Stochastic optimization algorithm; External influences;

Interrelated KCs; Quality loss;

Parameter, tolerance design; Surrogate model; Multiobjective optimization;

Multiobjective optimization; Robust tolerance design; Quality loss; ANOVA; Parameter, tolerance design; 10.1016/j.procir.2015.04.035

10.1016/j.procir.2015.04.087

10.1080/0740817X.2016.1167289

10.1002/qre. 1991 
Table 2 (continued)

\begin{tabular}{|c|c|c|c|c|}
\hline Year & Author & Title & Keywords & DOI/ISBN \\
\hline 2016 & B. Heling & $\begin{array}{l}\text { On Connected Tol- } \\
\text { erances in Statistical } \\
\text { Tolerance-Cost- } \\
\text { Optimization of } \\
\text { Assemblies with Interre- } \\
\text { lated Dimension } \\
\text { Chains }\end{array}$ & $\begin{array}{l}\text { Interrelated KCs; } \\
\text { Monte Carlo sampling; } \\
\text { Stochastic optimization } \\
\text { algorithm; }\end{array}$ & 10.1016/j.procir.2016.02.031 \\
\hline 2016 & Y. Ledoux & $\begin{array}{l}\text { Global optimisation of } \\
\text { functional requirements } \\
\text { and tolerance allocations } \\
\text { based on designer prefer- } \\
\text { ence modelling }\end{array}$ & $\begin{array}{l}\text { Stochastic optimization } \\
\text { algorithm; Ontological } \\
\text { model; }\end{array}$ & $10.1080 / 09544828.2016 .1191625$ \\
\hline 2016 & L. Ramesh Kumar & $\begin{array}{l}\text { Design and optimization } \\
\text { of concurrent toler- } \\
\text { ance in mechanical } \\
\text { assemblies using bat } \\
\text { algorithm }\end{array}$ & $\begin{array}{l}\text { Concurrent tolerance } \\
\text { design; Stochastic opti- } \\
\text { mization algorithm; } \\
\text { Quality loss; Concurrent } \\
\text { tolerance design; }\end{array}$ & 10.1007/s12206-016-0521-y \\
\hline 2016 & L. Ramesh Kumar & $\begin{array}{l}\text { Least cost-tolerance } \\
\text { allocation based on } \\
\text { Lagrange multiplier }\end{array}$ & $\begin{array}{l}\text { Lagrange multiplier } \\
\text { method; Multiobjective } \\
\text { optimization; Quality } \\
\text { loss; Alternative process } \\
\text { selection; }\end{array}$ & $10.1177 / 1063293 X 15625722$ \\
\hline 2016 & L. Ramesh Kumar & $\begin{array}{l}\text { Optimal tolerance } \\
\text { allocation in a complex } \\
\text { assembly using evolu- } \\
\text { tionary algorithms }\end{array}$ & $\begin{array}{l}\text { Stochastic optimization } \\
\text { algorithm; Quality loss; }\end{array}$ & 10.2507/IJSIMM15(1)10.331 \\
\hline 2016 & A. Sanz-Lobera & $\begin{array}{l}\text { A proposal of cost- } \\
\text { tolerance models directly } \\
\text { collected from the manu- } \\
\text { facturing process }\end{array}$ & $\begin{array}{l}\text { Tolerance-cost func- } \\
\text { tions; Manufacturing } \\
\text { process; Part dimension } \\
\text { distributions; }\end{array}$ & $10.1080 / 00207543.2015 .1086036$ \\
\hline 2016 & D. Vignesh Kumar & $\begin{array}{l}\text { Optimum tolerance } \\
\text { synthesis of simple } \\
\text { assemblies with nomi- } \\
\text { nal dimension selection } \\
\text { using genetic algorithm }\end{array}$ & $\begin{array}{l}\text { Stochastic optimization } \\
\text { algorithm; Parame- } \\
\text { ter, tolerance design; } \\
\text { Alternative process } \\
\text { selection; }\end{array}$ & $10.1177 / 0954406215613366$ \\
\hline 2016 & M. L. Wang & $\begin{array}{l}\text { Research on assembly } \\
\text { tolerance allocation and } \\
\text { quality control based on } \\
\text { fuzzy reliability }\end{array}$ & $\begin{array}{l}\text { Quality loss; Fuzzy the- } \\
\text { ory; Orthogonal array; }\end{array}$ & $10.1177 / 0954406215615909$ \\
\hline 2016 & Y. M. Zhao & $\begin{array}{l}\text { Optimal tolerance design } \\
\text { of product based on ser- } \\
\text { vice quality loss }\end{array}$ & $\begin{array}{l}\text { Quality loss; Service } \\
\text { costs; Present worth; }\end{array}$ & $10.1007 / \mathrm{s} 00170-015-7480-9$ \\
\hline 2017 & C. Balamurugan & $\begin{array}{l}\text { Concurrent optimal allo- } \\
\text { cation of geometric and } \\
\text { process tolerances based } \\
\text { on the present worth of } \\
\text { quality loss using evolu- } \\
\text { tionary optimisation } \\
\text { techniques }\end{array}$ & $\begin{array}{l}\text { Concurrent toler- } \\
\text { ance design; GD\&T; } \\
\text { Stochastic optimization } \\
\text { algorithm; Quality loss; } \\
\text { Present worth; }\end{array}$ & $10.1007 / \mathrm{s} 00163-016-0230-7$ \\
\hline 2017 & M. Ghali & $\begin{array}{l}\text { A CAD method for tol- } \\
\text { erance allocation consid- } \\
\text { ering manufacturing dif- } \\
\text { ficulty based on FMECA } \\
\text { tool }\end{array}$ & $\begin{array}{l}\text { Lagrange multiplier } \\
\text { method; CAD; FMECA; }\end{array}$ & 10.1007/s00170-016-9961-x \\
\hline 2017 & M. Ghali & $\begin{array}{l}\text { An approach to unique } \\
\text { transfer and allocation }\end{array}$ & $\begin{array}{l}\text { Lagrange multiplier } \\
\text { method; CAD; FMECA; }\end{array}$ & - \\
\hline
\end{tabular}


Table 2 (continued)

\begin{tabular}{|c|c|c|c|c|}
\hline Year & Author & Title & Keywords & DOI/ISBN \\
\hline 2017 & N. Jawahar & $\begin{array}{l}\text { Optimal Pareto front for } \\
\text { manufacturing tolerance } \\
\text { allocation model }\end{array}$ & $\begin{array}{l}\text { Multiobjective optimiza- } \\
\text { tion; Assembly costs; }\end{array}$ & $10.1177 / 0954405415586548$ \\
\hline 2017 & G. Kaisarlis & $\begin{array}{l}\text { A novel tolerance design } \\
\text { approach to manufactur- } \\
\text { ing and quality loss cost } \\
\text { optimization in mechani- } \\
\text { cal assemblies }\end{array}$ & $\begin{array}{l}\text { Optimization algorithm; } \\
\text { Quality loss; }\end{array}$ & 10.15866/ireme.v11i9.11794 \\
\hline 2017 & C. N. Rosyidi & $\begin{array}{l}\text { A concurrent optimiza- } \\
\text { tion model for supplier } \\
\text { selection with fuzzy } \\
\text { quality loss }\end{array}$ & $\begin{array}{l}\text { External supply; Quality } \\
\text { loss; Fuzzy theory; }\end{array}$ & 10.3926/jiem.800 \\
\hline 2017 & D. S. L. Shoukr & $\begin{array}{l}\text { The Reduced Tolerance } \\
\text { Allocation Problem }\end{array}$ & $\begin{array}{l}\text { Stochastic optimiza- } \\
\text { tion algorithm; DOE; } \\
\text { Orthogonal array; }\end{array}$ & 10.1115/imece2016-65848 \\
\hline 2017 & S. Xu & $\begin{array}{l}\text { Multi-objective opti- } \\
\text { mization based } \\
\text { on improved non- } \\
\text { dominated sorting } \\
\text { genetic algorithm II for } \\
\text { tolerance allocation of } \\
\text { auto-body parts }\end{array}$ & $\begin{array}{l}\text { Multiobjective optimiza- } \\
\text { tion; Type-2-Assembly; } \\
\text { Compliant system; }\end{array}$ & $10.1177 / 1687814017718123$ \\
\hline 2017 & W. Zeng & $\begin{array}{l}\text { An effective strategy for } \\
\text { improving the precision } \\
\text { and computational effi- } \\
\text { ciency of statistical toler- } \\
\text { ance optimization }\end{array}$ & $\begin{array}{l}\text { Monte Carlo sampling; } \\
\text { Stochastic optimization } \\
\text { algorithm; }\end{array}$ & $10.1007 / \mathrm{s} 00170-017-0256-7$ \\
\hline 2018 & M. Ghali & $\begin{array}{l}\text { Optimal tolerance } \\
\text { allocation based on } \\
\text { Difficulty matrix using } \\
\text { FMECA tool }\end{array}$ & $\begin{array}{l}\text { Lagrange multiplier } \\
\text { method; CAD; FMECA; }\end{array}$ & 10.1016/j.procir.2018.03.005 \\
\hline 2018 & M. Hallmann & $\begin{array}{l}\text { Comparison of dif- } \\
\text { ferent methods for } \\
\text { scrap rate estimation } \\
\text { in sampling-based } \\
\text { tolerance-cost- } \\
\text { optimization }\end{array}$ & $\begin{array}{l}\text { Latin hypercube sam- } \\
\text { pling; Non-conformance } \\
\text { rate; Stochastic } \\
\text { optimization algorithm; }\end{array}$ & 10.1016/j.procir.2018.01.005 \\
\hline 2018 & S. Khodaygan & $\begin{array}{l}\text { Meta-model based multi- } \\
\text { objective optimisation } \\
\text { method for computer- } \\
\text { aided tolerance design of } \\
\text { compliant assemblies }\end{array}$ & $\begin{array}{l}\text { Multiobjective optimiza- } \\
\text { tion; Compliant system; } \\
\text { Surrogate model; }\end{array}$ & 10.1080/0951192X.2018.1543953 \\
\hline 2018 & B. Ma & $\begin{array}{l}\text { Robust Tolerance Design } \\
\text { Optimization of a PM } \\
\text { Claw Pole Motor With } \\
\text { Soft Magnetic Compos- } \\
\text { ite Cores }\end{array}$ & $\begin{array}{l}\text { Robust tolerance design; } \\
\text { Non-geometrical KC; }\end{array}$ & 10.1109/tmag.2017.2756262 \\
\hline 2018 & J. Natarajan & $\begin{array}{l}\text { Bi-objective opti- } \\
\text { mization for tol- } \\
\text { erance allocation in an } \\
\text { interchangeable assem- } \\
\text { bly under diverse manu- } \\
\text { facturing environment }\end{array}$ & $\begin{array}{l}\text { Multiobjective optimiza- } \\
\text { tion; GD\&T; Quality } \\
\text { loss; }\end{array}$ & $10.1007 / \mathrm{s} 00170-017-1232-\mathrm{y}$ \\
\hline 2019 & M. Tlija & $\begin{array}{l}\text { Integrated CAD tol- } \\
\text { erancing model based } \\
\text { on difficulty coefficient } \\
\text { evaluation and Lagrange } \\
\text { multiplier }\end{array}$ & $\begin{array}{l}\text { Lagrange multiplier } \\
\text { method; CAD; FMECA; }\end{array}$ & $10.1007 / \mathrm{s} 00170-018-3140-1$ \\
\hline
\end{tabular}


Table 2 (continued)

\begin{tabular}{|c|c|c|c|c|}
\hline Year & Author & Title & Keywords & DOI/ISBN \\
\hline 2018 & D. Vignesh Kumar & $\begin{array}{l}\text { Tolerance allocation } \\
\text { of complex assembly } \\
\text { with nominal dimension } \\
\text { selection using Artificial } \\
\text { Bee Colony algorithm }\end{array}$ & $\begin{array}{l}\text { Stochastic optimization } \\
\text { algorithm; Parameter, } \\
\text { tolerance design; }\end{array}$ & $10.1177 / 0954406218756439$ \\
\hline 2019 & J. Benzaken & $\begin{array}{l}\text { Physics-Informed Tol- } \\
\text { erance Allocation: A } \\
\text { Surrogate-Based Frame- } \\
\text { work for the Control of } \\
\text { Geometric Variation on } \\
\text { System Performance }\end{array}$ & $\begin{array}{l}\text { Optimization algorithm; } \\
\text { Compliant system; }\end{array}$ & - \\
\hline 2019 & Y. Wang & $\begin{array}{l}\text { Allocation of assembly } \\
\text { tolerances to minimize } \\
\text { costs }\end{array}$ & $\begin{array}{l}\text { Scrap cost; Quality loss; } \\
\text { Monte Carlo sampling; } \\
\text { Process capability index; }\end{array}$ & 10.1016/j.cirp.2019.04.027 \\
\hline
\end{tabular}

\section{References}

1. Srinivasan V (2007) Computational metrology for the design and manufacture of product geometry: a classification and synthesis. J Comput Inf Sci Eng 7(1):3-9. https://doi.org/10.1115/1. 2424246

2. Wartzack S, Meerkamm H, Stockinger A, Stoll T, Stuppy J, Voß R, Walter M, Wittmann S (2011) Lifecycle-oriented tolerance simulation. Konstruktion 2011(6):63-67+74

3. Zhang C, Wang HPB (1993) Integrated tolerance optimisation with simulated annealing. Int J Adv Manuf Technol 8(3):167174. https://doi.org/10.1007/BF01749907

4. Sfantsikopoulos MM (1990) A cost-tolerance analytical approach for design and manufacturing. Int $\mathrm{J}$ Adv Manuf Technol 5(2):126-134. https://doi.org/10.1007/BF02601602

5. Dong Z (1997) Tolerance synthesis by manufacturing cost modeling and design optimization. In: Zhang HC (ed) Advanced tolerancing techniques. Wiley-Interscience, New York, pp 233260

6. Haq AN, Sivakumar K, Saravanan R, Muthiah V (2005) Tolerance design optimization of machine elements using genetic algorithm. Int J Adv Manuf Technol 25(3-4):385-391. https://doi.org/10.1007/s00170-003-1855-Z

7. Chen MS (1996) Optimising tolerance allocation for mechanical components correlated by selective assembly. Int J Adv Manuf Technol 12(5):349-355. https://doi.org/10.1007/BF01179810

8. Patel AM (1980) Computer-aided assignment of manufacturing tolerances. In: DAC ' 80 Proceedings of the 17th Design Automation Conference, pp 129-133. https://doi.org/10.1145/800139. 804521

9. Singh PK, Jain PK, Jain SC (2009) Important issues in tolerance design of mechanical assemblies. Part 2: Tolerance synthesis. Proc Inst Mech Eng Part B J Eng Manuf 223(10):1249-1287. https://doi.org/10.1243/09544054JEM1304B

10. Chou CY, Chang CL (2000) Bivariate tolerance design for lock wheels by considering quality loss. Qual Reliab Eng Int 16(2):129-138. https://doi.org/10.1002/(SICI)1099-1638 (200003/04)16:2<129::AID-QRE310>3.0.CO;2-J

11. Schmitt R, Behrens C (2007) A statistical method for analyses of cost- and risk- optimal tolerance allocations based on assured input data. In: Weckenmann A (ed) Book of abstracts - 10th CIRP conference on computer aided tolerancing, specification and verification for assemblies. Shaker Verlag $\mathrm{GmbH}$, Aachen
12. Hallmann M, Schleich B, Heling B, Aschenbrenner A, Wartzack $S$ (2018) Comparison of different methods for scrap rate estimation in sampling-based tolerance-cost-optimization. Procedia CIRP 75:51-56. https://doi.org/10.1016/j.procir.2018.01. 005

13. Brückner K, Storch M, Hallmann M, Heling B, Schleich B, Wartzack S (2019) A novel approach to the identification of tolerance-cost-relationships in serial production. Konstruktion 11-12:84-90

14. Zhang G (1996) Simultaneous tolerancing for design and manufacturing. Int J Prod Res 34(12):3361-3382. https://doi.org/10. 1080/00207549608905095

15. Peng HP, Jiang XQ, Liu XJ (2008) Concurrent optimal allocation of design and process tolerances for mechanical assemblies with interrelated dimension chains. Int J Prod Res 46(24):6963-6979. https://doi.org/10.1080/00207540701427037

16. Creveling CM (1997) Tolerance design: a handbook for developing optimal specifications. Prentice Hall, New Jersey

17. Zhang C, Wang HP, Li JK (1992) Simultaneous optimization of design and manufacturing - tolerances with process (machine) selection. CIRP Ann - Manuf Technol 41(1):569-572. https://doi.org/10.1016/S0007-8506(07)61270-0

18. Karmakar S, Maiti J (2012) A review on dimensional tolerance synthesis: paradigm shift from product to process. Assem Autom 32(4):373-388. https://doi.org/10.1108/01445151211262438

19. Roy U, Liu C, Woo $T$ (1991) Review of dimensioning and tolerancing: representation and processing. Comput Des 23(7):466-483. https://doi.org/10.1016/0010-4485(91)90045-X

20. Purohit K, Sharma CS (1999) Recent developments in tolerancing techniques. Def Sci J 49(4):291-298. https://doi.org/10. 14429/dsj.49.3841

21. Sampath Kumar R, Soundararajan V, Alagumurthi N (2011) Review of Tolerance Analysis, Allocation and Constraints in Manufacturing. J Manuf Sci Prod 10(1):1-16. https://doi.org/10.1515/ijmsp.2009.10.1.1

22. Hallmann M, Goetz S, Schleich B (2019) Mapping of GD\&t information and PMI between 3D product models in the STEP and STL format. CAD Comput Aided Des 115:293-306. https://doi.org/10.1016/j.cad.2019.06.006

23. Ulrich KT, Eppinger SD (2011) Product design and development. McGraw-Hill, New York

24. Kackar RN (1985) Off-Line Quality control, parameter design, and the Taguchi method. J Qual Technol 17(4):176-188. https://doi.org/10.1080/00224065.1985.11978964 
25. Taguchi G, Chowdhury S, Wu Y (2005) Taguchi's quality engineering handbook. Wiley, New Jersey

26. Goetz S, Hartung J, Schleich B, Wartzack S (2019) Robustness evaluation of product concepts based on function structures. Proc Des Soc Int Conf Eng Des 1(1):3521-3530. https://doi.org/10.1017/dsi.2019.359

27. Eifler T, Ebro M, Howard TJ (2013) A classification of the industrial relevance of robust design methods. In: International Conference on Engineering Design, ICED13, Seoul, pp 427436

28. Tsui KL (1992) An overview of Taguchi method and newly developed statistical methods for robust design. IIE 24(5):44-57. https://doi.org/10.1080/07408179208964244

29. Kusiak A, Feng CX (1996) Robust tolerance design for quality. J Eng Ind 118(1):166-169. https://doi.org/10.1115/1.2803639

30. Jeang A (2001) Computer-aided tolerance synthesis with statistical method and optimization techniques. Qual Reliab Eng Int 17(2):131-139. https://doi.org/10.1002/qre.387

31. Hu J, Peng Y (2007) Tolerance modelling and robust design for concurrent engineering. Proc Inst Mech Eng Part C J Mech Eng Sci 221(4):455-465. https://doi.org/10.1243/0954406JMES438

32. Soderberg R (1993) Tolerance allocation considering customer and manufacturer objectives. In: Gilmore BJ (ed) Advances in design automation, vol 65-2. ASME, Albuquerque, pp 149157

33. Jeang A (1994) Tolerance design: choosing optimal tolerance specifications in the design of machined parts. Qual Reliab Eng Int 10(1):27-35. https://doi.org/10.1002/qre.4680100107

34. Cheng BW, Maghsoodloo S (1995) Optimization of mechanical assembly tolerances by incorporating Taguchi's quality loss function. J Manuf Syst 14(4):264-276. https://doi.org/10.1016/ 0278-6125(95)98879-B

35. Weill R (1988) Integrating dimensioning and tolerancing in computer-aided process planning. Robot Comput Integr Manuf 4(1-2):41-48. https://doi.org/10.1016/0736-5845(88)90058-0

36. Cagan J, Kurfess TR (1991) Optimal design for tolerance and manufacturing allocation. https://doi.org/10.1184/R1/6490064. v1

37. Dong Z, Wang GG (1998) Integrated concurrent design of tolerance using empirical manufacturing cost models, pp 1-18

38. Lee WJ, Woo TC (1989) Optimum selection of discrete tolerances. J Mech Transm Autom Des 111(2):243-251. https://doi.org/10.1115/1.3258990

39. Hong YS, Chang TC (2002) A comprehensive review of tolerancing research. Int J Prod Res 40(11):2425-2459. https://doi.org/10.1080/00207540210128242

40. Irani SA, Mittal RO, Lehtihet EA (1989) Tolerance chart optimization. Int J Prod Res 27(9):1531-1552. https://doi.org/10.1080/00207548908942638

41. Whybrew K, Britton GA, Robinson DF, Sermsutianuwat Y (1990) A graph-theoretic approach to tolerance charting. Int J Adv Manuf Technol 5(2):175-183. https://doi.org/10.1007/ BF02601605

42. Wade OR (1967) Tolerance control in design and manufacturing. Industrial Press Inc, New York

43. Bryan NKA, Michael SMS (1996) Tolerance synthesis adopting a nonlinear programming approach. Int J Adv Manuf Technol 11(6):387-393. https://doi.org/10.1007/BF01178964

44. Ngoi BKA (1992) Applying linear programming to tolerance chart balancing. Int J Adv Manuf Technol 7(4):187-192. https://doi.org/10.1007/BF02601622

45. Wu Z, ElMaraghy WH, ElMaraghy HA (1988) Evaluation of Cost-Tolerance algorithms for design tolerance analysis and synthesis. Manuf Rev ASME 1(3):168-179
46. Dong Z, Wang GG (1990) Automated tolerance optimization using feature-driven, production operation-based cost models

47. Ahluwalia RS, Karolin AV (1984) CATC-a computer aided tolerance control system. J Manuf Syst 3(2):153-160. https://doi.org/10.1016/0278-6125(84)90006-2

48. Ngoi BK, Fang SL (1994) Computer-aided tolerance charting. Int J Prod Res 32(8):1939-1954. https://doi.org/10.1080/ 00207549408957051

49. Li W, Bai G, Zhang C, Wang B (2000) Optimization of machining datum selection and machining tolerance allocation with genetic algorithms. Int J Prod Res 38(6):1407-1424. https://doi.org/10.1080/002075400188924

50. Ngoi BKA, Teck OC (1997) A tolerancing optimisation method for product design. Int J Adv Manuf Technol 13(4):290-299. https://doi.org/10.1007/BF01179611

51. Huang M, Zhong Y (2008) Dimensional and geometrical tolerance balancing in concurrent design. Int $\mathbf{J}$ Adv Manuf Technol 35(7-8):723-735. https://doi.org/10.1007/s00170-006-0749-2

52. Geetha K, Ravindran D, Siva Kumar M, Islam MN (2015) Concurrent tolerance allocation and scheduling for complex assemblies. Robot Comput Integr Manuf 35:84-95. https://doi.org/10.1016/j.rcim.2015.03.001

53. Balamurugan C, Saravanan A, Dinesh Babu P, Jagan P, Ranga S, Narasimman S (2017) Concurrent optimal allocation of geometric and process tolerances based on the present worth of quality loss using evolutionary optimisation techniques. Res Eng Des 28(2):185-202. https://doi.org/10.1007/s00163-016-0230-7

54. Dupinet É, Balazinski M, Czogala E (1996) Tolerance allocation based on fuzzy logic and simulated annealing. J Intell Manuf 7(6):487-497. https://doi.org/10.1007/BF00122838

55. Diplaris SC, Sfantsikopoulos MM (2000) Cost-tolerance function. a new approach for cost optimum machining accuracy. Int J Adv Manuf Technol 16(1):32-38. https://doi.org/10.1007/ PL00013129

56. Schleich B (2017) Skin model shapes: a new paradigm for the tolerance analysis and the geometrical variations modelling in mechanical engineering. VDI Verlag, Dússeldorf

57. Thornton AC (1999) A mathematical framework for the key characteristic process. Res Eng Des 11(3):145-157. https://doi.org/ 10.1007/s001630050011

58. Armillotta A (2013) A method for computer-aided specification of geometric tolerances. CAD Comput Aided Des 45(12):16041616. https://doi.org/10.1016/j.cad.2013.08.007

59. Morse E, Dantan JY, Anwer N, Sóderberg R, Moroni G, Qureshi A, Jiang X, Mathieu L (2018) Tolerancing: managing uncertainty from conceptual design to final product. CIRP Ann 67(2):695717. https://doi.org/10.1016/j.cirp.2018.05.009

60. Singh PK, Jain PK, Jain SC (2009) Important issues in tolerance design of mechanical assemblies. Part 1: Tolerance analysis. Proc Inst Mech Eng Part B J Eng Manuf 223(10):1225-1247. https://doi.org/10.1243/09544054JEM1304A

61. Schleich B, Anwer N, Mathieu L, Wartzack S (2017) Shaping the digital twin for design and production engineering. CIRP Ann - Manuf Technol 66(1):141-144. https://doi.org/10.1016/j. cirp.2017.04.040

62. Lee WJ, Woo TC (1990) Tolerances: their analysis and synthesis. J Eng Ind 112(2):113. https://doi.org/10.1115/1.2899553

63. Ostwald PF, Huang J (1977) A method for optimal tolerance selection. J Eng Ind 99(3):558-565. https://doi.org/10.1115/1. 3439279

64. Speckhart FH (1972) Calculation of tolerance based on a minimum cost approach. J Eng Ind 94(2):447-453. https://doi.org/10.1115/1.3428175

65. Singh PK, Jain SC, Jain PK (2004) A genetic algorithm based solution to optimum tolerance synthesis of mechanical 
assemblies with alternate manufacturing processes - benchmarking with the exhaustive search method using the Lagrange multiplier. Proc Inst Mech Eng Part B J Eng Manuf 218(7):765778. https://doi.org/10.1177/095440540421800709

66. Vasseur H, Kurfess T, Cagan J (1992) Optimal tolerance allocation for improved productivity. IFAC Proc 25(8):211-218. https://doi.org/10.1016/s1474-6670(17)54066-5

67. Cheikh A, McGoldrick PF (1988) The influence of cost, function and process capability on tolerance. Int J Qual Reliab Manag 5(3):15-28. https://doi.org/10.1108/eb002904

68. Peters J (1970) Tolerancing the components of an assembly for minimum cost. J Eng Ind 92(3):677-682. https://doi.org/10. $1115 / 1.3427830$

69. Latta LW (1963) Least-cost tolerancing. Prod Eng 16:111-113

70. Chase KW (1988) Design issues in mechanical tolerance analysis. Manuf Rev ASME 1(1):50-59

71. Mansoor EM (1963) The application of probability to tolerances used in engineering designs. Proc Inst Mech Eng 178(1):29-39. https://doi.org/10.1177/002034836317800104

72. Bjørke Ø (1979) Computer-aided tolerancing. Tapir, Trondheim

73. Fortini ET (1967) Dimensioning for interchangeable manufacture. Inustrial Press Inc, New York

74. Ji S, Li X, Ma Y, Cai H (2000) Optimal tolerance allocation based on fuzzy comprehensive evaluation and genetic algorithm. Int J Adv Manuf Technol 16(7):461-468. https://doi.org/10.1007/s001700070053

75. Dong Z, Hu W, Xue D (1994) New production cost-tolerance models for tolerance synthesis. J Eng Ind 116(2):199-206. https://doi.org/10.1115/1.2901931

76. Sayed SEY, Kheir NA (1985) An efficient technique for minimum-cost tolerance assignment. Simulation 44(4):189-195. https://doi.org/10.1177/003754978504400404

77. Schleich B, Anwer N, Zhu Z, Qiao L, Mathieu L, Wartzack S (2014) A comparative study on tolerance analysis approaches. 1st Int Symp Robust Des ISoRD14 pp 29-39

78. Iannuzzi MP, Sandgren E (1996) Tolerance optimization using genetic algorithms: benchmarking with manual analysis. In: Kimura F (ed) Computer-aided tolerancing. Chapman \& Hall, London, pp 219-234. https://doi.org/10.1007/978-94-009-15299_15

79. Lin CY, Huang WH, Jeng MC, Doong JL (1997) Study of an assembly tolerance allocation model based on Monte Carlo simulation. J Mater Process Technol 70(1-3):9-16. https://doi.org/10.1016/S0924-0136(97)00034-4

80. Feng CX, Kusiak A (2000) Robust tolerance synthesis with the design of experiments approach. J Manuf Sci Eng 122(3):520 528. https://doi.org/10.1115/1.1285860

81. Gerth RJ, Klonaris P, Pfeiffer T (1999) Cost tolerance sensitivity analysis for concurrent engineering design support. In: van Houten F, Kals $\mathrm{H}$ (eds) Global consistency of tolerances. Springer, Dordrecht, pp 313-324. https://doi.org/10.1007/97894-017-1705-2_32

82. Kusiak A, Feng CX (1995) Deterministic tolerance synthesis: a comparative study. Comput Des 27(10):759-768. https://doi.org/10.1016/0010-4485(94)00028-C

83. Şehirlioğlu AK, Ozler C (2008) The use of mixture experiments in tolerance allocation problems. Int $\mathrm{J}$ Adv Manuf Technol 35(7-8):769-777. https://doi.org/10.1007/s00170-0060754-5

84. Karafin BJ (1971) Statistical circuit design: the optimum assignment of component tolerances for electrical networks. Bell Syst Tech J 50(4):1225-1242. https://doi.org/10.1002/j.1538-7305. 1971.tb02552.x

85. Parkinson DB (1985) Assessment and optimization of dimensional tolerances. Comput Des 17(4):191-199. https://doi.org/10. 1016/0010-4485(85)90216-7
86. Gadallah MH, ElMaraghy HA (1994) A new algorithm for discrete tolerance optimization. In:Proceedings of the Fourth International Conference on Computer Integrated Manufacturing and Automation Technology, Troy, pp 292-297. https://doi.org/10.1109/cimat.1994.389058

87. Ngoi BKA, Ong CT (1998) Product and process dimensioning and tolerancing techniques. a state-of-the-art review. Int $\mathbf{J}$ Adv Manuf Technol 14(12):910-917. https://doi.org/10.1007/ BF01179081

88. Evans DH (1958) Optimum tolerance assignment to yield minimum manufacturing cost. Bell Syst Tech J 37(2):461-484. https://doi.org/10.1002/j.1538-7305.1958.tb01529.x

89. Siva Kumar M, Stalin B (2009) Optimum tolerance synthesis for complex assembly with alternative process selection using Lagrange multiplier method. Int J Adv Manuf Technol 44(34):405-411. https://doi.org/10.1007/s00170-008-1866-x

90. Geetha K, Ravindran D, Siva Kumar M, Islam MN (2013) Multi-objective optimization for optimum tolerance synthesis with process and machine selection using a genetic algorithm. Int J Adv Manuf Technol 67(9-12):2439-2457. https://doi.org/10.1007/s00170-012-4662-6

91. Lee J, Johnson GE (1993) Optimal tolerance allotment using a genetic algorithm and truncated Monte Carlo simulation. Comput Des 25(9):601-611. https://doi.org/10.1016/0010-4485(93) 90075-Y

92. Lin SS, Wang HPB, Zhang CC (1997) Optimal tolerance design for integrated design, manufacturing, and inspection with genetic algorithms. In: Zhang HC (ed) Advanced tolerancing techniques. Wiley-Interscience, New York, pp 261-281

93. Dimitrellou SC, Diplaris SC, Sfantsikopoulos MM (2007) A systematic approach for cost optimal tolerance design. Proceedings of ICED 2007, the 16th International Conference on Engineering Design, 16th Int. Conf. Eng. Des., Paris, pp 1-9

94. Prabhaharan G, Asokan P, Ramesh P, Rajendran S (2004) Genetic-algorithm-based optimal tolerance allocation using a least-cost model. Int J Adv Manuf Technol 24(9-10):647-660. https://doi.org/10.1007/s00170-003-1606-1

95. Muthu P, Dhanalakshmi V, Sankaranarayanasamy K (2009) Optimal tolerance design of assembly for minimum quality loss and manufacturing cost using metaheuristic algorithms. Int J Adv Manuf Technol 44(11-12):1154-1164. https://doi.org/10.1007/ s00170-009-1930-1

96. Wilde D, Prentice E (1975) Minimum exponential cost allocation of sure-fit tolerances. J Eng Ind 97(4):1395-1398. https://doi.org/10.1115/1.3438796

97. Chase KW (1999) Minimum-cost tolerance allocation. In: Drake PJ (ed) Dimensioning and tolerancing handbook. McGraw-Hill, New York, pp 14-1-23

98. Walter MSJ, Spruegel TC, Wartzack S (2015) Least cost tolerance allocation for systems with time-variant deviations. Procedia CIRP 27:1-9. https://doi.org/10.1016/j.procir.2015.04.035

99. Chase KW, Greenwood WH, Loosli BG, Hauglund LF (1990) Least cost tolerance allocation for mechanical assemblies with automated process selection. Manuf Rev 3(1):49-59

100. Nagarwala MY, Simin Pulat P, Raman SA (1995) Slopebased method for least cost tolerance allocation. Concurr Eng 3(4):319-328. https://doi.org/10.1177/1063293X9500300407

101. Bennett G, Gupta LC (1970a) Least-cost tolerances-I. Int J Prod Res 8(1):65-74. https://doi.org/10.1080/00207547008929830

102. Bennett G, Gupta LC (1970b) Least-cost tolerances-II. Int J Prod Res 8(2):169-182. https://doi.org/10.1080/00207547008929838

103. Söderberg R (1994) Robust design by tolerance allocation considering quality and manufacturing cost. In: Gilmore BJ (ed) Advances in design automation, vol 69-2. ASME, Minneapolis, pp 219-226 
104. Wang Y, Li L, Hartman NW, Sutherland JW (2019) Allocation of assembly tolerances to minimize costs. CIRP Ann 68(1):13-16. https://doi.org/10.1016/j.cirp.2019.04.027

105. Michael W, Siddall JN (1981) The optimization problem with optimal tolerance assignment and full acceptance. J Mech Des 103(4):842-848. https://doi.org/10.1115/1.3254996

106. Michael W, Siddall JN (1982) The optimal tolerance assignment with less than full acceptance. J Mech Des 104(4):855-860. https://doi.org/10.1115/1.3256448

107. Dong Z, Hu W (1991) Optimal process sequence identification and optimal process tolerance assignment in computer-aided process planning. Comput Ind 17(1):19-32. https://doi.org/10.1016/0166-3615(91)90100-N

108. Monte ME, Datseris P (1982) Optimum tolerance selection for minimum manufacturing cost and other design criteria. ASME Tech Pap DECT ASME Paper, pp 1-9

109. Singh PK, Jain SC, Jain PK (2006) Concurrent optimal adjustment of nominal dimensions and selection of tolerances considering alternative machines. CAD Comput Aided Des 38(10):1074-1087. https://doi.org/10.1016/j.cad.2006.05.006

110. Cao SK, Li ZQ, Gao Q, Xu J (2008) Tolerance optimal design system development and application based on UG quick stack module. Appl Mech Mater 10-12:801-805. https://doi.org/10.4028/www.scientific.net/AMM.10-12.801

111. Sivakumar K, Balamurugan C, Ramabalan S (2012) Evolutionary multi-objective concurrent maximisation of process tolerances. Int J Prod Res 50(12):3172-3191. https://doi.org/10.1080/00207543.2010.550637

112. Sampath Kumar R, Ramesh R, Alagumurthi RN (2010) Integrated optimization of machining tolerance and asymmetric quality loss cost for rotor key base assembly, International conference on recent advances in Mechanical Engineering (ICRAME2010)

113. Guo C, Zhao B, Hu B, Xi P (2010) The research and realization on computer-aided aircraft tolerance design based on UG. 2010 Int Conf Mech Autom Control Eng MACE2010, pp 388-391. https://doi.org/10.1109/MACE.2010.5535581

114. Vignesh Kumar D, Ravindran D, Siva Kumar M, Islam MN (2016) Optimum tolerance synthesis of simple assemblies with nominal dimension selection using genetic algorithm. Proc Inst Mech Eng Part C J Mech Eng Sci 230(19):3488-3508. https://doi.org/10.1177/0954406215613366

115. Deng J, Deng S (2002) The adaptive branch and bound method of tolerance synthesis based on the reliability index. Int $\mathbf{J}$ Adv Manuf Technol 20(3):190-200. https://doi.org/10.1007/ s001700200142

116. Jeang A, Chang CL (2002) Concurrent optimisation of parameter and tolerance design via computer simulation and statistical method. Int J Adv Manuf Technol 19(6):432-441. https://doi.org/10.1007/s001700200045

117. Singh PK, Jain SC, Jain PK (2005) Advanced optimal tolerance design of mechanical assemblies with interrelated dimension chains and process precision limits. Comput Ind 56(2):179-194. https://doi.org/10.1016/j.compind.2004.06.008

118. Walter MSJ, Wartzack S (2013) Statistical tolerance-costoptimization of systems in motion taking into account different kinds of deviations. In: Abramovici M, Stark R (eds) Smart product engineering. Lecture Notes in Production Engineering. Springer, Berlin, pp 705-714. https://doi.org/10.1007/978-3642-30817-8_69

119. Rao SS (2009) Engineering optimization: theory and practice. Wiley, New Jersey

120. Gonzalez I, Sánchez I (2009) Statistical tolerance synthesis with correlated variables. Mech Mach Theory 44(6):1097-1107.1012:801-805. https://doi.org/10.1016/j.mechmachtheory.2008. 10.006
121. Zhang C, Ben Wang HP (1993) Tolerance analysis and synthesis for cam mechanisms. Int J Prod Res 31(5):1229-1245. https://doi.org/10.1080/00207549308956785

122. Rout BK, Mittal RK (2010) Simultaneous selection of optimal parameters and tolerance of manipulator using evolutionary optimization technique. Struct Multidiscip Optim 40:513-528. https://doi.org/10.1007/s00158-009-0368-2

123. Prabhaharan G, Asokan P, Rajendran S (2005) Sensitivity-based conceptual design and tolerance allocation using the continuous ants colony algorithm (CACO). Int J Adv Manuf Technol 25(56):516-526. https://doi.org/10.1007/s00170-003-1846-0

124. Shoukr DSL, Gadallah MH, Metwalli SM (2017) The reduced tolerance allocation problem. In: Proceedings of the ASME 2016 International Mechanical Engineering Congress and Exposition, pp 1-10. https://doi.org/10.1115/imece2016-65848

125. Robles N, Roy U (2004) Optimal tolerance allocation and process-sequence selection incorporating manufacturing capacities and quality issues. J Manuf Syst 23(2):127-133. https://doi.org/10.1016/S0278-6125(05)00002-6

126. Mao J, Cao YL, Liu SQ, Yang JX (2009) Manufacturing environment-oriented robust tolerance optimization method. Int J Adv Manuf Technol 41(1-2):57-65. https://doi.org/10.1007/ s00170-008-1460-2

127. Yang XS (2010) Nature-inspired metaheuristic algorithms. Luniver Press, Frome

128. Siddique N, Adeli H (2015) Nature inspired computing: an overview and some future directions. Cognit Comput 7(6):706714. https://doi.org/10.1007/s12559-015-9370-8

129. Nesmachnow S (2014) An overview of metaheuristics: accurate and efficient methods for optimisation. Int $\mathrm{J}$ Metaheuristics 3(4):320-346. https://doi.org/10.1504/ijmheur.2014.068914

130. Bandler JW (1974) Optimization of design tolerances using nonlinear programming. J Optim Theory Appl 14(1):99-114. https://doi.org/10.1007/BF00933176

131. Lee WJ, Woo TC, Chou SY (1993) Tolerance synthesis for nonlinear systems based on nonlinear programming. IIE Trans 25(1):51-61. https://doi.org/10.1080/07408179308964265

132. Feng CX, Kusiak A (1997) Robust tolerance design with the integer programming approach. J Manuf Sci Eng 119(4A):603610. https://doi.org/10.1115/1.2831193

133. Singh PK, Jain PK, Jain SC (2004) A genetic algorithmbased solution to optimal tolerance synthesis of mechanical assemblies with alternative manufacturing processes: focus on complex tolerancing problems. Int J Prod Res 42(24):51855215. https://doi.org/10.1080/00207540410001733931

134. Ashiagbor A, Liu HC, Nnaji BO (1998) Tolerance control and propagation for the product assembly modeller. Int J Prod Res 36(1):75-94. https://doi.org/10.1080/002075498193949

135. Zhang C, Wang HP (1993) The discrete tolerance optimization problem. Manuf Rev 6(1):60-71

136. Singh PK, Jain SC, Jain PK (2005) Comparative study of genetic algorithm and simulated annealing for optimal tolerance design formulated with discrete and continuous variables. Proc Inst Mech Eng Part B J Eng Manuf 219(10):735-760. https://doi.org/10.1243/095440505X32643

137. Chen TC, Fischer GW (2000) A GA-based search method for the tolerance allocation problem. Artif Intell Eng 14(2):133-141. https://doi.org/10.1016/S0954-1810(00)00006-6

138. Shan A, Roth RN, Wilson RJ (2003) Genetic algorithms in statistical tolerancing. Math Comput Model 38(11-13):14271436. https://doi.org/10.1016/S0895-7177(03)90146-4

139. Sivakumar K, Balamurugan C, Ramabalan S (2011) Concurrent multi-objective tolerance allocation of mechanical assemblies considering alternative manufacturing process selection. Int J Adv Manuf Technol 53(5-8):711-732. https://doi.org/10.1007/s00170-010-2871-4 
140. Al-Ansary MD, Deiab IM (1997) Concurrent optimization of design and machining tolerances using the genetic algorithms method. Int J Mach Tools Manuf 37(12):1721-1731. https://doi.org/10.1016/S0890-6955(97)00033-3

141. Jayaprakash G, Sivakumar K, Thilak M (2010) Parametric tolerance analysis of mechanical assembly using FEA and cost competent tolerance synthesis using neural network. J Softw Eng Appl 3(12):1148-1154. https://doi.org/10.4236/jsea.2010. 312134

142. Sivakumar K, Balamurugan C, Ramabalan S (2010) Evolutionary sensitivity-based conceptual design and tolerance allocation for mechanical assemblies. Int J Adv Manuf Technol 48(14):307-324. https://doi.org/10.1007/s00170-009-2256-8

143. Sivakumar K, Balamurugan C, Ramabalan S, Venkata Raman SB (2009) Optimal concurrent dimensional and geometrical tolerancing based on evolutionary algorithms. In: 2009 World congress on nature and biologically inspired computing, NABIC 2009 - proceedings. IEEE, Coimbatore, pp 300-305. https://doi.org/10.1109/NABIC.2009.5393725

144. Andolfatto L, Thiébaut F, Lartigue C, Douilly M (2014) Qualityand cost-driven assembly technique selection and geometrical tolerance allocation for mechanical structure assembly. J Manuf Syst 33(1):103-115. https://doi.org/10.1016/j.jmsy.2013.03.003

145. Jayaprakash G, Sivakumar K, Thilak M (2011) Integration of thermo mechanical strains into optimal tolerance design of mechanical assembly using NSGA II and FE simulations. J Mech Eng Res 3(6): 168-180

146. Forouraghi B (2009) Optimal tolerance allocation using a multiobjective particle swarm optimizer. Int J Adv Manuf Technol 44(7-8):710-724. https://doi.org/10.1007/s00170-008-1892-8

147. Qiu HB, Dong YY, Wang Y, Gao L (2011) Tolerance optimization design based on physical programming methods and PSO algorithm. Adv Mater Res 346(7):584-592. https://doi.org/10.4028/www.scientific.net/ amr.346.584

148. Zhou C, Gao L, Gao HB, Zan K (2006) Particle swarm optimization for simultaneous optimization of design and machining tolerances. In: Wang TD (ed) Simulated evolution and learning. SEAL 2006. Lecture Notes in Computer Science, vol 4247. Springer, Berlin, pp 873-880. https://doi.org/10.1007/11903697_110

149. Towsyfyan H (2013) The comparison of imperialist competitive algorithm applied and genetic algorithm for machining allocation of clutch assembly. Int J Eng 26(12(C)):1485-1494

150. dos Santos Coelho L (2009) Self-organizing migration algorithm applied to machining allocation of clutch assembly. Math Comput Simul 80(2):427-435. https://doi.org/10.1016/j.matcom. 2009.08.003

151. Chen TC, Hsu TC (2006) An immune algorithm for least cost advanced tolerance design problem. Mater Sci Forum 505-507:511-516. https://doi.org/10.4028/www.scientific.net/ MSF.505-507.511

152. Zhijie Z, Li Y, Yu J, Tang S (2010) Optimal assembly tolerance design based on fuzzy information entropy and seeker optimization algorithm. In: 2010 3rd International Conference on Advanced Computer Theory and Engineering (ICACTE), vol 5, Chengdu, pp 610-613. https://doi.org/10.1109/ICACTE.2010.5579339

153. Ramesh Kumar L, Padmanaban KP, Kumar SG, Balamurugan C (2016) Design and optimization of concurrent tolerance in mechanical assemblies using bat algorithm. J Mech Sci Technol 30(6):2601-2614. https://doi.org/10.1007/s12206-016-0521-y

154. Vignesh Kumar D, Ravindran D, lenin N, Siva Kumar M (2018) Tolerance allocation of complex assembly with nominal dimension selection using Artificial Bee Colony algorithm. Proc Inst Mech Eng Part C J Mech Eng Sci 233(1):18-38. https://doi.org/10.1177/0954406218756439
155. Zeng W, Rao Y, Wang P (2017) An effective strategy for improving the precision and computational efficiency of statistical tolerance optimization. Int J Adv Manuf Technol 92(58):1933-1944. https://doi.org/10.1007/s00170-017-0256-7

156. Rao RV, More KC (2013) Simultaneous optimal selection of design and manufacturing tolerances with different stack- up conditions using TLBO algorithm. International Conference on Innovations in Engineering and Technology (ICIET'2013) Dec. 25-26, 2013 Bangkok (Thailand)

157. Rao RV, More KC (2014) Advanced optimal tolerance design of machine elements using teaching-learning-based optimization algorithm. Prod Manuf Res 2(1):71-94. https://doi.org/10.1080/ 21693277.2014.892845

158. Singh PK, Jain PK, Jain SC (2008) Optimal tolerance design of mechanical assemblies for economical manufacturing in the presence of alternative machines - a genetic algorithm-based hybrid methodology. Proc Inst Mech Eng Part B J Eng Manuf 222(5):591-604. https://doi.org/10.1243/09544054JEM967

159. Zahara E, Kao YT (2009) A hybridized approach to optimal tolerance synthesis of clutch assembly. Int J Adv Manuf Technol 40(11-12):1118-1124. https://doi.org/10.1007/s00170-0081418-4

160. Shringi D, Purohit K (2013) Simultaneous optimization of tolerances for prismatic part assembly in different stack up conditions. Int J Mining. Metall Mech Eng 1(2):183-186

161. Siva Kumar M, Kannan SM, Jayabalan V (2009) A new algorithm for optimum tolerance allocation of complex assemblies with alternative processes selection. Int J Adv Manuf Technol 40(7-8):819-836. https://doi.org/10.1007/s00170-008-1389-5

162. Wang Q, Stockton DJ, Baguley P (2000) Process cost modelling using neural networks. Int J Prod Res 38(16):3811-3821. https://doi.org/10.1080/00207540050176021

163. Zhao YM, Liu DS, Wen ZJ (2014) Optimization design method of product general tolerance system. Int J Adv Manuf Technol 70(1-4):363-374. https://doi.org/10.1007/s00170-013-5193-5

164. Huang Q, Shi J (2003) Simultaneous tolerances synthesis through variation propagation modeling of multistage manufacturing processes. NAMRI/SME Trans 31:515-522

165. Moroni G, Petró S, Tolio T (2011) Early cost estimation for tolerance verification. CIRP Ann 60(1):195-198. https://doi.org/10.1016/j.cirp.2011.03.010

166. Lee YH, Wei CC, Chen CB, Tsai CH (2000) Minimization of scrap and rework costs by process tolerances allocation. Eng Optim 32(5):619-633. https://doi.org/10.1080/0305215000 8941315

167. Shin S, Cho BR (2007) Integrating a bi-objective paradigm to tolerance optimization. Int J Prod Res 45(23):5509-5525. https://doi.org/10.1080/00207540701325181

168. Jawahar N, Sivasankaran R, Ramesh M (2017) Optimal Pareto front for manufacturing tolerance allocation model. Proc Inst Mech Eng Part B J Eng Manuf 231(7):1190-1203. https://doi.org/10.1177/0954405415586548

169. Chen Y, Ding Y, Jin J, Ceglarek D (2006) Integration of processoriented tolerancing and maintenance planning in design of multistation manufacturing processes. IEEE Trans Autom Sci Eng 3(4):440-453. https://doi.org/10.1109/TASE.2006.872105

170. Zhao YM, Liu DS, Wen ZJ (2016) Optimal tolerance design of product based on service quality loss. Int J Adv Manuf Technol 82(9-12):1715-1724. https://doi.org/10.1007/s00170-0157480-9

171. Hoffenson S, Dagman A, Söderberg R (2013a) Tolerance specification optimization for economic and ecological sustainability. In: Abramovici M, Stark R (eds) Smart product engineering. Lecture Notes in Production Engineering. Springer, Berlin, pp 865-874. https://doi.org/10.1007/978-3-642-30817-8_85 
172. Hoffenson S, Dagman A, Söderberg R (2013b) A multi-objective tolerance optimization approach for economic, ecological, and social sustainability. In: Nee A, Song B, Ong SK (eds) Reengineering manufacturing for sustainability. Springer, Singapore, pp 729-734. https://doi.org/10.1007/978-981-4451-48$2 \_119$

173. Hoffenson S, Dagman A, Söderberg R (2014) Tolerance optimisation considering economic and environmental sustainability. $\mathrm{J}$ Eng Des 25(10-12):367-390. https://doi.org/10.1080/09544828. 2014.994481

174. Feng Q, Kapur KC (2008) Quality engineering: control, design and optimization. In: Misra KB (ed) Handbook of Performability Engineering. Springer, London, pp 171-186. https://doi.org/10.1007/978-1-84800-131-2_13

175. Terän A, Pratt DB, Case KE (1996) Present worth of external quality losses for symmetric nominal-is-better quality characteristics. Eng Econ 42(1):39-52. https://doi.org/10.1080/ 00137919608903168

176. Chou CY, Chang CL (2001) Minimum-loss assembly tolerance allocation by considering product degradation and time value of money. Int J Adv Manuf Technol 17(2):139-146. https://doi.org/10.1007/s001700170202

177. Lin ZC, Chang DY (2002) Cost-tolerance analysis model based on a neural networks method. Int J Prod Res 40(6):1429-1452. https://doi.org/10.1080/00207540110116282

178. Sanz-Lobera A, Gómez E, Pèrez J, Sevilla L (2016) A proposal of cost-tolerance models directly collected from the manufacturing process. Int J Prod Res 54(15):4584-4598. https://doi.org/10.1080/00207543.2015.1086036

179. Trucks H (1987) Designing for economical production. Society of Manufacturing Engineers, Dearborn

180. Peat AP (1968) Cost reduction charts for designers and production engineers. The Machinery Publishing Co, London

181. Dieter GE (1983) Engineering design: a materials and processing approach. McGraw-Hill, New York

182. Johnson RC (1958) The cost of finishes and tolerances. J Am Soc Nav Eng 70(4):607-614. https://doi.org/10.1111/j.1559-3584. 1958.tb01777.x

183. Jamieson A (1982) Introduction to quality control. Reston Pub Co, Paramus

184. Gerth RJ, Pfeifer T (2000) Minimum cost tolerancing under uncertain cost estimates. IIE Trans 32(6):493-503. https://doi.org/10.1023/A:1007667818580

185. He JR (1991) Tolerancing for manufacturing via cost minimization. Int $\mathrm{J}$ Mach Tools Manuf 31(4):455-470. https://doi.org/10.1016/0890-6955(91)90029-3

186. Huele AF, Engel J (2006) A response surface approach to tolerance design. Stat Neerl 60(3):379-395. https://doi.org/10.1111/j. 1467-9574.2006.00332.x

187. Chen MC (2001) Tolerance synthesis by neural learning and nonlinear programming. Int $\mathrm{J}$ Prod Econ 70(1):55-65. https://doi.org/10.1016/S0925-5273(00)00044-X

188. Cao Y, Zhang H, Mao J, Yang J (2010) Novel costtolerance model based on fuzzy neural networks. Proc Inst Mech Eng Part B J Eng Manuf 224(11):1757-1765. https://doi.org/10.1243/09544054JEM1789

189. Siddall JN (1982) Optimal engineering design: principles and applications. CRC Press, Boca Raton

190. Feng CX, Wang J, Wang JS (2001) An optimization model for concurrent selection of tolerances and suppliers. Comput Ind Eng 40(1-2):15-33. https://doi.org/10.1016/S0360-8352(00)00047-4

191. Nur Rosyidi C, Rizkichani Akbar R, Ahmad Jauhari W (2014) Make or buy analysis model based on tolerance design to minimize manufacturing cost and quality loss. Makara J Technol 18(2):86-90. https://doi.org/10.7454/mst.v18i2.2947
192. Nur Rosyidi C, Murtisari R, Ahmad Jauhari W (2017) A concurrent optimization model for supplier selection with fuzzy quality loss. J Ind Eng Manag 10(1):98-110. https://doi.org/10.3926/ jiem. 800

193. Saravanan A, Balamurugan C, Sivakumar K, Ramabalan S (2014) Optimal geometric tolerance design framework for rigid parts with assembly function requirements using evolutionary algorithms. Int J Adv Manuf Technol 73(9-12):1219-1236. https://doi.org/10.1007/s00170-014-5908-2

194. Vasseur H, Kurfess TR, Cagan J (1997) Use of a quality loss function to select statistical tolerances. J Manuf Sci Eng 119(3):410-416. https://doi.org/10.1115/1.2831121

195. Hsieh KL (2006) The study of cost-tolerance model by incorporating process capability index into product lifecycle cost. Int $\mathrm{J}$ Adv Manuf Technol 28(5-6):638-642. https://doi.org/10.1007/s00170-004-2385-Z

196. Yeo SH, Ngoi BK, Chen H (1998) Process sequence optimization based on a new cost-tolerance model. J Intell Manuf 9(1):29-37. https://doi.org/10.1023/A:1008895224256

197. Yeo SH, Ngoi BK, Chen H (1996) A cost-tolerance model for process sequence optimisation. Int J Adv Manuf Technol 12(6):423-431. https://doi.org/10.1007/BF01186931

198. Dong J, Shi Y (1997) Tolerance analysis and synthesis in variational design. In: Zhang $\mathrm{HC}$ (ed) Advanced tolerancing techniques. Wiley-Interscience, New York, pp 310-325

199. Kao SC (2010) Deciding optimal specification limits and process adjustments under quality loss function and process capability indices. Int J Ind Eng Theory Appl Pract 17(3):212222

200. Huang YM, Shiau CS (2009) An optimal tolerance allocation model for assemblies with consideration of manufacturing cost, quality loss and reliability index. Assem Autom 29(3):220-229. https://doi.org/10.1108/01445150910972903

201. Yang K, Xie W, He Y (1994) Parameter and tolerance design in the engineering modelling stage. Int J Prod Res 32(12):28032816. https://doi.org/10.1080/00207549408957101

202. Jeang A (1995) Economic tolerance design for quality. Qual Reliab Eng Int 11(2):113-121. https://doi.org/10.1002/qre. 4680110207

203. Cho BR, Kim YJ, Kimbler DL, Phillips MD (2000) An integrated joint optimization procedure for robust and tolerance design. Int J Prod Res 38(10):2309-2325. https://doi.org/10.1080/ 00207540050028115

204. Maghsoodloo S, Li MHC (2000) Optimal asymmetric tolerance design. IIE Trans 32(12):1127-1137. https://doi.org/10.1080/ 07408170008967467

205. Plante R (2002) Multivariate tolerance design for a quadratic design parameter model. IIE Trans 34(6):565-571. https://doi.org/10.1023/A:1013926727053

206. Natarajan J, Sivasankaran R, Kanagaraj G (2018) Biobjective optimization for tolerance allocation in an interchangeable assembly under diverse manufacturing environment. Int J Adv Manuf Technol 95(5-8):1571-1595. https://doi.org/10.1007/s00170-017-1232-y

207. Sampath Kumar R, Alagumurth N, Ramesh R (2009) Calculation of total cost, tolerance based on Taguchi's, asymmetric quality loss function approach. Am J Eng Appl Sci 2(4):628-634. https://doi.org/10.3844/ajeassp.2009.628.634

208. Li MHC (2000) Quality loss function based manufacturing process setting models for unbalanced tolerance design. Int J Adv Manuf Technol 16(1):39-45. https://doi.org/10.1007/ PL00013130

209. Liao MY (2010) Economic tolerance design for folded normal data. Int J Prod Res 48(14):4123-4137. https://doi.org/10.1080/00207540902960307 
210. Jin Q, Liu S, Wang P (2015) Optimal tolerance design for products with non-normal distribution based on asymmetric quadratic quality loss. Int J Adv Manuf Technol 78(1-4):667675. https://doi.org/10.1007/s00170-014-6681-y

211. Cao Y, Mao J, Ching H, Yang J (2009) A robust tolerance optimization method based on fuzzy quality loss. Proc Inst Mech Eng Part C J Mech Eng Sci 223(11):2647-2653. https://doi.org/10.1243/09544062JMES1451

212. Wang ML, Liu XT, Wang YS, Wang XL, Guo H, Xing YF (2016) Research on assembly tolerance allocation and quality control based on fuzzy reliability. Proc Inst Mech Eng Part C J Mech Eng Sci 230(20):3755-3766. https://doi.org/10.1177/ 0954406215615909

213. Yang B, Yang T, Ze X (2007) Functional tolerance theory in incremental growth design. Front Mech Eng China 2(3):336343. https://doi.org/10.1007/s11465-007-0059-x

214. Chen G, Kapur KC (1994) Tolerance design by break-even analysis for reducing variation and cost. Int J Reliab Qual Saf Eng 01(04):445-457. https://doi.org/10.1142/S0218539394000313

215. Rao YS, Rao CSP, Janardhana GR, Vundavilli PR (2011) Simultaneous tolerance synthesis for manufacturing and quality using evolutionary algorithms. Int J Appl Evol Comput 2(2):120. https://doi.org/10.4018/jaec.2011040101

216. Zong Y, Mao J (2015) Tolerance optimization design based on the manufacturing-costs of assembly quality. Procedia CIRP 27:324-329. https://doi.org/10.1016/j.procir.2015.04.087

217. Huang YM, Shiau CS (2005) Optimal tolerance allocation for a sliding vane compressor. J Mech Des 128(1):98-107. https://doi.org/10.1115/1.2114893

218. Pinel JF, Roberts KA (1972) Tolerance assignment in linear networks using nonlinear programming. IEEE Trans Circuit Theory 19(5):475-479. https://doi.org/10.1109/TCT.1972.1083506

219. Thorbjornsen AR, Director SW (1973) Computer-aided tolerance assignment for linear circuits with correlated elements. IEEE Trans Circ Theory 20(5):518-524. https://doi.org/10.1109/ TCT.1973.1083737

220. Grey DS (1970) Tolerance sensitivity and optimization. Appl Opt 9(3):523-526. https://doi.org/10.1364/ao.9.000523

221. Jung S, Choi DH, Choi BL, Kim JH (2011) Tolerance optimization of a mobile phone camera lens system. Appl Opt 50(23):4688-4700. https://doi.org/10.1364/ao.50.004688

222. Bernardo FP, Saraiva PM (1998) Robust optimization framework for process parameter and tolerance design. AIChE J 44(9):2007-2017. https://doi.org/10.1002/aic.690440908

223. Li W, Wu CFJ (1999) An integrated method of parameter design and tolerance design. Qual Eng 11(3):417-425. https://doi.org/10.1080/08982119908919258

224. Kovach J, Chander V, Cho BR (2004) The tolerance optimization for a skewed process distribution. In: Proceedings of the 2004 Industrial Engineering Research Conference, pp 1925-1930

225. Jeong SH, Kongsuwan P, Truong NKV, Shin S (2013) Optimal tolerance design and optimization for a pharmaceutical quality characteristic. Math Probl Eng 2013:1-17. https://doi.org/10.1155/2013/706962

226. Dantan JY, Gayton N, Etienne A, Qureshi AJ (2012) Mathematical issues in mechanical tolerance analysis. In: Proceedings of the 13th Colloque National AIP PRIMECA, Le Mont Dore

227. Sigurdarson N, Eifler T, Ebro M (2018) The Applicability of CAT tools in industry - boundaries and challenges in tolerance engineering practice observed in a medical device company. Procedia CIRP 75:261-266. https://doi.org/10.1016/j.procir.2018. 04.066

228. Gerth RJ, Islam Z (1998) Towards a designed experiments approach to tolerance design. In: ElMaraghy HA (ed) Geometric design tolerancing: theories, standards and applications.
Springer, Boston, pp 337-345. https://doi.org/10.1007/9781-4615-5797-5_26

229. Whitney DE (2004) Mechanical assemblies: their design, manufacture and role in product development. Oxford University Press, Oxford

230. Söderberg R, Lindkvist L (1999) Computer aided assembly robustness evaluation. J Eng Des 10(2):165-181. https://doi.org/10.1080/095448299261371

231. Cheng KM, Tsai JC (2011) A closed-form approach for optimum tolerance allocation of assemblies with general tolerance-cost function. Adv Mater Res 201-203:1272-1278. https://doi.org/10.4028/www.scientific.net/ amr.201-203.1272

232. Siva Kumar M, Islam MN, Lenin N, Vignesh Kumar D (2009) Optimum tolerance synthesis for complex assembly with alternative process selection using bottom curve follower approach. Int J Eng 3(4):380-402

233. Peng HP, Jiang XQ, Xu ZG, Liu XJ (2008) Optimal tolerance design for products with correlated characteristics by considering the present worth of quality loss. Int J Adv Manuf Technol 39(1-2):1-8. https://doi.org/10.1007/s00170-0071205-7

234. Sutherland GH, Roth B (1975) Mechanism design: accounting for manufacturing tolerances and costs in function generating problems. J Eng Ind 97(1):283-286. https://doi.org/10.1115/1. 3438551

235. Heling B, Aschenbrenner A, Walter MSJ, Wartzack S (2016) On connected tolerances in statistical tolerance-cost-optimization of assemblies with interrelated dimension chains. Procedia CIRP 43:262-267. https://doi.org/10.1016/j.procir.2016.02.031

236. Mustajib MI (2012) Concurrent engineering of tolerance synthesis and process selection for products with multiple quality characteristics considering process capability. Makara J Technol 16(1):7-14. https://doi.org/10.7454/mst.v16i1.1040

237. Ramesh Kumar L, Padmanaban KP, Balamurugan C (2016) Least cost-tolerance allocation based on Lagrange multiplier. Concurr Eng Res Appl 24(2):164-177. https://doi.org/10.1177/ $1063293 X 15625722$

238. Lee CL, Tang GR (2000) Tolerance design for products with correlated characteristics. Mech Mach Theory 35(12):16751687. https://doi.org/10.1016/S0094-114X(00)00022-7

239. Hu J, Xiong G (2005) Concurrent design of a geometric parameter and tolerance for assembly and cost. Int J Prod Res 43(2):267293. https://doi.org/10.1080/00207540412331282051

240. Ceglarek D, Huang W, Zhou S, Ding Y, Kumar R, Zhou Y (2004) Time-based competition in multistage manufacturing: stream-of-variation analysis (SOVA) methodology - Review. Int J Flex Manuf Syst 16(1):11-44, https://doi.org/10.1023/B:FLEX.0000039171.25141.a4

241. Li Z, Yue J, Kokkolaras M, Camelio J, Papalambros PY, Hu SJ (2004) Product tolerance allocation in compliant multistation assembly through variation propagation and analytical target cascading. In: Proceedings of IMECE 2004 ASME International Mechanical Engineering Congress and Exposition, Anaheim, pp 813-820. https://doi.org/10.1115/imece2004-60521

242. Ding Y, Jin J, Ceglarek D, Shi J (2005) Process-oriented tolerancing for multi-station assembly systems. IIE Trans 37(6):493-508. https://doi.org/10.1080/07408170490507774

243. Cui A, Zhang HP (2010) Tolerance allocation and maintenance optimal design for fixture in multi-station panel assembly process. Appl Mech Mater 34-35:1039-1045. https://doi.org/ 10.4028/www.scientific.net/amm.34-35.1039

244. Li Z, Kokkolaras M, Papalambros P, Hu SJ (2008) Product and process tolerance allocation in multistation compliant assembly using analytical target cascading. J Mech Des 130(9):091701-1091701-9. https://doi.org/10.1115/1.2943296 
245. Xu S, Xing Y, Chen W (2017) Multi-objective optimization based on improved non-dominated sorting genetic algorithm II for tolerance allocation of auto-body parts. Adv Mech Eng 9(9):1-9. https://doi.org/10.1177/1687814017718123

246. Khodaygan S (2018) Meta-model based multi-objective optimisation method for computer-aided tolerance design of compliant assemblies. Int J Comput Integr Manuf 32(1):27-42. https://doi.org/10.1080/0951192X.2018.1543953

247. Shiu BW, Apley DW, Ceglarek D, Shi J (2003) Tolerance allocation for compliant beam structure assemblies. IIE Trans 35(4):329-342. https://doi.org/10.1080/07408170304376

248. Benzaken J, Doostan A, Evans JA (2019) Physics-informed tolerance allocation: a surrogate-based framework for the control of geometric variation on system performance

249. Litwa F, Gottwald M, Spudeiko S, Paetzold K, Vielhaber M (2016) Optimization coupling approach for/with non-static point based CAT-models. Procedia CIRP 43:166-171. https://doi.org/10.1016/j.procir.2016.02.034

250. Schleich B, Wartzack S (2012) How to determine the influence of geometric deviations on elastic deformations and the structural performance? Proc Inst Mech Eng Part B J Eng Manuf 227(5):754-764. https://doi.org/10.1177/0954405412468994

251. Eifler T, Howard TJ (2017) Exact constraint design and its potential for robust embodiment. Procedia CIRP 60:302-307. https://doi.org/10.1016/j.procir.2017.02.046

252. Roth K (2000) Die Theorie der logischen Schluß-Matrix. In: Konstruieren mit Konstruktionskatalogen. Springer, Berlin, pp 387-431. https://doi.org/10.1007/978-3-642-17466-7_9

253. Beaucaire P, Gayton N, Duc E, Lemaire M, Dantan JY (2012) Statistical tolerance analysis of a hyperstatic mechanism, using system reliability methods. Comput Ind Eng 63(4):1118-1127. https://doi.org/10.1016/j.cie.2012.06.017

254. Liu X, An L, Wang Z, Tan C, Wang X (2018) Tolerance analysis of over-constrained assembly considering gravity influence: constraints of multiple planar hole-pin-hole pairs. Math Probl Eng 2018:1-18. https://doi.org/10.1155/2018/2039153

255. Dumas A, Dantan JY, Gayton N (2015) Impact of a behavior model linearization strategy on the tolerance analysis of overconstrained mechanisms. CAD Comput Aided Des 62:152-163. https://doi.org/10.1016/j.cad.2014.11.002

256. Qureshi AJ, Dantan JY, Sabri V, Beaucaire P, Gayton N (2012) A statistical tolerance analysis approach for overconstrained mechanism based on optimization and Monte Carlo simulation. CAD Comput Aided Des 44(2):132-142. https://doi.org/10.1016/j.cad.2011.10.004

257. Dantan JY, Qureshi AJ (2009) Worst-case and statistical tolerance analysis based on quantified constraint satisfaction problems and Monte Carlo simulation. CAD Comput Aided Des 41(1):1-12. https://doi.org/10.1016/j.cad.2008.11.003

258. Ballu A, Plantec JY, Mathieu L (2008) Geometrical reliability of overconstrained mechanisms with gaps. CIRP Ann - Manuf Technol 57(1):159-162. https://doi.org/10.1016/j.cirp.2008. 03.038

259. Gouyou D, Ledoux Y, Teissandier D, Delos V (2018) Tolerance analysis of overconstrained and flexible assemblies by polytopes and finite element computations: application to a flange. Res Eng Des 29(1):55-66. https://doi.org/10.1007/s00163-017-0256-5

260. Wu F, Dantan JY, Etienne A, Siadat A, Martin P (2009) Improved algorithm for tolerance allocation based on Monte Carlo simulation and discrete optimization. Comput Ind Eng 56(4):1402-1413. https://doi.org/10.1016/j.cie.2008.09.005

261. Gadallah MH, ElMaraghy HA (1993) A concurrent engineering approach to robust product design. Concurr Eng 1(4):237-251. https://doi.org/10.1177/1063293X9300100407
262. Choi JH, Lee SJ, Choi DH (1998) Tolerance optimization for mechanisms with lubricated joints. Multibody Syst Dyn 2(2):145-168. https://doi.org/10.1023/A:1009785211763

263. Rhyu JH, Kwak BM (1988) Optimal stochastic design of four-bar mechanisms for tolerance and clearance. J Mech Transm Autom Des 110(3):255. https://doi.org/10.1115/1.3267455

264. Rao SS, Hati SK (1979) Game theory approach in multicriteria optimization of function generating mechanisms. J Mech Des 101(3):398-406. https://doi.org/10.1115/1.3454072

265. Chun H, Kwon SJ, Tak T (2008) Multibody approach for tolerance analysis and optimization of mechanical systems. J Mech Sci Technol 22(2):276-286. https://doi.org/10.1007/s12206-0071024-7

266. Krishnaswami P, Kelkar AG (2003) Optimal design of controlled multibody dynamic systems for performance, robustness and tolerancing. Eng Comput 19(1):26-34. https://doi.org/10.1007/ s00366-002-0246-

267. Jeang A, Chen TK, Hwan CL (2002) A statistical dimension and tolerance design for mechanical assembly under thermal impact. Int J Adv Manuf Technol 20(12):907-915. https://doi.org/10.1007/s001700200214

268. Parkinson A, Sorensen C, Pourhassan N (1993) A general approach for robust optimal design. J Mech Des 115(1):74-80. https://doi.org/10.1115/1.2919328

269. Mazur M, Leary M, Subic A (2015) Application of polynomial chaos expansion to tolerance analysis and synthesis in compliant assemblies subject to loading. J Mech Des 137(3):031701103701-16. https://doi.org/10.1115/1.4029283

270. Jayaprakash G, Thilak M, SivaKumar K (2014) Optimal tolerance design for mechanical assembly considering thermal impact. Int $\mathbf{J}$ Adv Manuf Technol 73(5-8):859-873. https://doi.org/10.1007/s00170-014-5845-0

271. Moskowitz H, Plante R, Duffy J (2001) Multivariate tolerance design using quality loss. IIE Trans 33(6):437-448. https://doi.org/10.1080/07408170108936843

272. Jayaprakash G, Sivakumar K, Thilak M (2012) A numerical study on effect of temperature and inertia on tolerance design of mechanical assembly. Eng Comput 29(7):722-742. https://doi.org/10.1108/02644401211257236

273. Skowronski VJ, Turner JU (1996) Estimating gradients for statistical tolerance synthesis. Comput Aided Des 28(12):933941. https://doi.org/10.1016/0010-4485(96)00032-2

274. Anselmetti B, Chavanne R, Yang JX, Anwer N (2010) Quick GPS : a new CAT system for single-part tolerancing. Comput Aided Des 42(9):768-780. https://doi.org/10.1016/j.cad.2010. 04.006

275. Ballu A, Mathieu L (1999) Choice of functional specifications using graphs within the framework of education. In: van Houten F, Kals H (eds) Global Consistency of Tolerances. Springer, Dodrecht, pp 197-206. https://doi.org/10.1007/978-94-0171705-2_20

276. Haghighi P, Mohan P, Kalish N, Vemulapalli P, Shah JJ, Davidson JK (2015) Toward automatic tolerancing of mechanical assemblies: first-order GD\&t schema development and tolerance allocation. J Comput Inf Sci Eng 15(4):1-9. https://doi.org/10.1115/1.4030939

277. Parkinson A (1995) Robust mechanical design using engineering models. J Vib Acoust 117(B):48-54. https://doi.org/10.1115/1. 2838676

278. Mathieu L, Ballu A (2007) A model for a coherent and complete tolerancing process. In: Davidson JK (ed) Models for computer aided tolerancing in design and manufacturing. Springer, Dordrecht, pp 35-44. https://doi.org/10.1007/1-4020-5438-6_5 
279. Governi L, Furferi R, Volpe Y (2012) A genetic algorithmsbased procedure for automatic tolerance allocation integrated in a commercial variation analysis software. J Artif Intell 5(3):99112. https://doi.org/10.3923/jai.2012.99.112

280. Jeang A (1999) Optimal tolerance design by response surface methodology. Int J Prod Res 37(14):3275-3288. https://doi.org/10.1080/002075499190284

281. Ledoux Y, Teissandier D, Sebastian P (2016) Global optimisation of functional requirements and tolerance allocations based on designer preference modelling. J Eng Des 27(9):591-612. https://doi.org/10.1080/09544828.2016.1191625

282. Chen H, Jin S, Li Z, Lai X (2015) A modified method of the unified Jacobian-Torsor model for tolerance analysis and allocation. Int J Precis Eng Manuf 16(8):1789-1800. https://doi.org/10.1007/s12541-015-0234-7

283. Li H, Zhu H, Zhou X, Li P, Yu Z (2016) A new computer-aided tolerance analysis and optimization framework for assembling processes using DP-SDT theory. Int J Adv Manuf Technol 86(5-8):1299-1310. https://doi.org/10.1007/s00170-015-8266-9

284. Pramanik N, Roy U, Sudarsan R, Sriram RD, Lyons KW (2005) A generic deviation-based approach for synthesis of tolerances. IEEE Trans Autom Sci Eng 2(4):358-368. https://doi.org/10.1109/TASE.2005.853584

285. Chase KW, Parkinson AR (1991) A survey of research in the application of tolerance analysis to the design of mechanical assemblies. Res Eng Des 3(1):23-37. https://doi.org/10.1007/ BF01580066

286. Srinivasan V (1999) Statistical Tolerancing. In: Drake PJ (ed) Dimensioning and tolerancing handbook. McGraw-Hill, New York, pp 8-1-10

287. Singh PK, Jain PK, Jain SC (2003) Simultaneous optimal selection of design and manufacturing tolerances with different stack-up conditions using genetic algorithms. Int J Prod Res 41 (11):2411-2429. https://doi.org/10.1080/0020754031000087328

288. Di Stefano P (2003) Tolerance analysis and synthesis using the mean shift model. Proc Inst Mech Eng Part C J Mech Eng Sci 217(2):149-159. https://doi.org/10.1243/095440603762826477

289. Krishna AG, Rao KM (2006) Simultaneous optimal selection of design and manufacturing tolerances with different stackup conditions using scatter search. Int J Adv Manuf Technol 30(3-4):328-333. https://doi.org/10.1007/s00170-005-0059-0

290. Mazur M, Leary M, Subic A (2014) A case study of efficient tolerance synthesis in product assemblies under loading. In: Proceedings of NordDesign 2014 Conference, pp 855-864

291. Ramos Barbero B, Pérez Azcona J, Gonzȧlez pèrez J (2015) A tolerance analysis and optimization methodology. The combined use of 3D CAT, a dimensional hierarchization matrix and an optimization algorithm. Int J Adv Manuf Technol 81(1-4):371385. https://doi.org/10.1007/s00170-015-7068-4

292. Lööf J, Hermansson T, Söderberg R (2007) An efficient solution to the discrete least-cost tolerance allocation problem with general loss functions. In: Davidson JK (ed) Models for computer aided tolerancing in design and manufacturing. Springer, Dodrecht, pp 115-124. https://doi.org/10.1007/1-4020-54386_13

293. Lööf J, Söderberg R (2012) Discrete tolerance allocation for product families. Eng Optim 44(1):75-85. https://doi.org/10. 1080/0305215X.2011.569545

294. Hoffenson S, Dagman A, Söderberg R (2015) Visual quality and sustainability considerations in tolerance optimization: a market-based approach. Int $\mathrm{J}$ Prod Econ 168:167-180. https://doi.org/10.1016/j.ijpe.2015.06.023

295. Wei C, Sun J, Xin-min L (2014) Tolerance optimization considerations applied to the sheet metal compliant assembly. Comput Aided Des Appl 11(sup1):68-76. https://doi.org/10.1080/ 16864360.2014 .914413
296. Renzi C, Ceruti A, Leali F (2018) Integrated geometrical and dimensional tolerances stack-up analysis for the design of mechanical assemblies: an application on marine engineering. Comput Aided Des Appl 15(5):631-642. https://doi.org/10. 1080/16864360.2018.1441229

297. Jordaan JP, Ungerer CP (2002) Optimization of design tolerances through response surface approximations. J Manuf Sci Eng Trans ASME 124(3):762-767. https://doi.org/10.1115/1.1381400

298. Han M, Yong Tan MH (2016) Integrated parameter and tolerance design with computer experiments. IIE Trans 48(11):1004-1015. https://doi.org/10.1080/0740817X.2016.1167289

299. Han M, Tan MHY (2017) Optimal robust and tolerance design for computer experiments with mixture proportion inputs. Qual Reliab Eng Int 33(8):2255-2267. https://doi.org/10.1002/qre. 2188

300. Bowman RA (2009) Efficient gradient-based tolerance optimization using Monte Carlo simulation. J Manuf Sci Eng 131(3):031005-1-8. https://doi.org/10.1115/1.3123328

301. Lin CW (2012) Simultaneous optimal design of parameters and tolerance of bearing locations for high-speed machine tools using a genetic algorithm and Monte Carlo simulation method. Int J Precis Eng Manuf 13(11):1983-1988. https://doi.org/10.1007/s12541-012-0261-6

302. Nassef AO, ElMaraghy HA (1997) Allocation of geometric tolerances: New criterion and methodology. CIRP Ann 46(1):101-106. https://doi.org/10.1016/s0007-8506(07) 60785-9

303. Kubiak T, Benbow D (2009) The certified six sigma black belt handbook. ASQ Quality Press, Milwaukee

304. Savage GJ, Tong D, Carr SM (2006) Optimal mean and tolerance allocation using conformance-based design. Qual Reliab Eng Int 22(4):445-472. https://doi.org/10.1002/qre.721,

305. Di Stefano P (2006) Tolerances analysis and cost evaluation for product life cycle. Int J Prod Res 44(10):1943-1961. https://doi.org/10.1080/00207540500465832

306. Zhang CC, Wang PHB (1998) Robust design of assembly and machining tolerance allocations. IIE Trans 30(1):17-29. https://doi.org/10.1080/07408179808966434

307. Etienne A, Dantan JY, Qureshi J, Siadat A (2008) Variation management by functional tolerance allocation and manufacturing process selection. Int J Interact Des Manuf 2(4):207-218. https://doi.org/10.1007/s12008-008-0055-3

308. Söderberg R (1994) Tolerance allocation in a CAD environment considering quality and manufacturing cost. In: Lean production: from concept to product, Irish Manufacturing Comittee 11, Belfast, pp 789-800

309. Ramani B, Cheraghi SH, Twomey JM (1998) CAD-based integrated tolerancing system. Int J Prod Res 36(10):2891-2910. https://doi.org/10.1080/002075498192535

310. Kanai S, Onozuka M, Takahashi H (1996) Optimal tolerance synthesis by genetic algorithm under the machining and assembling constraints. In: Kimura F (ed) Computeraided Tolerancing. Chapman \& Hall, London, pp 235-250. https://doi.org/10.1007/978-94-009-1529-9_16

311. Lu SCY, Wilhelm RG (1991) Automating tolerance synthesis: a framework and tools. J Manuf Syst 10(4):279-296. https://doi.org/10.1016/0278-6125(91)90023-U

312. Xue D, Dong Z (1994) Developing a quantitative intelligent system for implementing concurrent engineering design. J Intell Manuf 5(4):251-267. https://doi.org/10.1007/BF00123697

313. Dong Z, Wang GG (1998) Automated cost modeling for tolerance synthesis using manufacturing process data, knowledge reasoning and optimization. In: ElMaraghy HA (ed) Geometric design tolerancing: theories, standards and applications. Springer, Dodrecht, pp 282-293. https://doi.org/10.1007/9781-4615-5797-5_22 
314. Domazet DS, Lu SCY, Kalajdzic M (1992) Concurrent design and process planning of rotational parts. CIRP Ann - Manuf Technol 41(1):181-184. https://doi.org/10.1016/S0007-8506(07) 61180-9

315. Janakiraman V, Saravanan R (2010) Concurrent optimization of machining process parameters and tolerance allocation. Int J Adv Manuf Technol 51(1-4):357-369. https://doi.org/10.1007/s00170-010-2602-x

316. Kirkpatrick S, Gelatt CD, Vecchi MP (1983) Optimization by simulated annealing. Science 220(4598):671-680. https://doi.org/10.1126/science.220.4598.671

317. Goldberg DE (1989) Genetic algorithms in search, optimization, and machine learning. Addison-Wesley, Boston

318. Eberhart R, Kennedy J (1999) A new optimizer using particle swarm theory. Sixth Int Symp Micro Mach Hum Sci 0-7803267:39-43. https://doi.org/10.1109/MHS.1995.494215
319. Wu CC, Chen Z, Tang GR (1998) Component tolerance design for minimum quality loss and manufacturing cost. Comput Ind 35(3):223-232. https://doi.org/10.1016/s0166-3615(97)00087-0

320. Sanz-Lobera A, Sebastián MA, Pérez JM (2010) New costtolerance model for mechanical part design. Int J Adv Manuf Technol 51(5-8):421-430. https://doi.org/10.1007/s00170-0102661-z

321. Schleich B, Wärmefjord K, Söderberg R, Wartzack S (2018) Geometrical Variations Management 4.0: towards next generation geometry assurance. Procedia CIRP 75:3-10. https://doi.org/10.1016/j.procir.2018.04.078

Publisher's note Springer Nature remains neutral with regard to jurisdictional claims in published maps and institutional affiliations. 